\title{
CIUDAD DE CORRIENTES: TESTIMONIOS NO CONDENATORIOS HACIA LA ÚLTIMA DICTADURA MILITAR
}

Una descripción de memorias colectivas 
Agradecimientos:

A cada de las personas entrevistadas que me recibieron en sus hogares, abriéndome el paso a sus memorias. 


\section{Índice}

Índice — 2

Presentación__ 4

Capítulo I_ 11

Cuestiones metodológicas y marco teórico___ 11

Cuestiones metodológicas ___ 11

Marco teórico: la especificidad del trabajo con memorias sobre la última dictadura ___ 17

¿Cómo pensamos los imaginarios sociales? ___ 20

Capítulo II__ 22

Contexto histórico: la relación "dictadura-sociedad" en la Argentina de la década del setenta

Capítulo III__ 28

Estado del arte: "testimonios no condenatorios hacia la última dictadura militar" por parte de otras/os autoras/es_ 28

Testimonios No Condenatorios en coincidencia. Los TNC no existen solo en Corrientes... ___ 32

Capítulo IV 40

Testimonios No Condenatorios hacia el gobierno militar, análisis de entrevistas ___ 40

Los Testimonios No Condenatorios y las conexiones entre el pasado y el presente __ 43

Narrativas de lo sucedido: conocimientos sobre las causas de la toma del poder por parte de los militares en 1976 y explicaciones acerca de qué sucedía en el país ___ 46

Los "valores" relacionados con la política. Los ideales de gobierno y de ciudadana/o ___ 54

Ideales de ciudadana/o ___ 54

Ideales de gobierno ___ 61

Las "emociones" relacionadas con el período militar y las narrativas acerca de experiencias personales ___ 72

La cuestión de los derechos humanos____________________ 80

¿No pasaba nada en Corrientes durante la dictadura? ___ 85

Capítulo $5 \longrightarrow 95$

Los TNC se contraponen a la memoria estatal kirchnerista __ 95 
Memorias del último gobierno militar en Argentina, en general, y en Corrientes, en particular 95

Funcionamiento de la memoria 101

Los Testimonios No Condenatorios y las narrativas coincidentes con los diarios correntinos de la década del setenta 106

Narrativas de lo sucedido: cuáles son consideradas las causas de la asunción de los militares en 1976 107

Ideales de ciudadano 111

Ideales de gobierno 114

Las narrativas de los diarios en la década de los setenta 118

Capítulo 6 121

A modo de cierre: ¿Qué son los Testimonios No Condenatorios? 121

Las narrativas de lo sucedido 125

Los ideales de ciudadanos 125

Los ideales de gobierno 126

Experiencias personales de las personas entrevistadas durante el gobierno militar 127 


\section{Presentación}

"La memoria se declina siempre en el presente y éste determina sus modalidades: la selección de acontecimientos que el recuerdo debe guardar, los testigos a escuchar, su lectura, sus lecciones."

Traverso $^{l}$

El presente trabajo de investigación se enmarca dentro de los estudios de Historia Reciente, tomando como objeto de estudio las memorias colectivas formadas por Testimonios No Condenatorios hacia la última dictadura militar (en adelante TNC), por parte de correntinas y correntinos que vivieron dicho período.

La inspiración para investigar nace a partir de experiencias personales vividas durante el período de tiempo correspondiente a la presidencia de Cristina Fernández de Kirchner en la República Argentina, período en el cual -y desde la presidencia de Néstor Kirchner- se podía constatar una hegemonía del discurso de los derechos humanos, que -si bien dicho movimiento había surgido en la década del setenta en Argentina-, será durante sus presidencias cuando se realizaron las entrevistas pertinentes a este trabajo de investigación.

El discurso oficial, referente al período militar, desarrollado durante dichas presidencias kirchneristas se basa, en líneas generales, en la consigna "memoria, verdad y justicia", reivindica a las víctimas del terrorismo de Estado, exige juicio y castigo a los militares que cometieron crímenes y presenta a la dictadura como el período más oscuro de la historia nacional y el deber de recordar lo que sucedió para que no se vuelva a repetir. Parafraseando a Martín Retamozo (2011): La respuesta estatal a las demandas históricas de los organismos de derechos humanos sobre los crímenes cometidos durante la dictadura militar fue uno de los rasgos más notables de la gestión de Néstor Kirchner.

Asimismo, el kirchnerismo elaboró un discurso que posicionó al gobierno en el mismo campo que los movimientos sociales y con los mismos enemigos en común: el neoliberalismo, la dictadura

\footnotetext{
${ }^{1}$ Traverso, en Franco y Levín, 2007, pág. 7.
} 
militar, las diferentes corporaciones, el FMI, entre otras. En términos de Lvovich (2008): "la última dictadura militar que gobernó la Argentina es, en la actualidad, repudiada de manera casi unánime. La memoria de los horrores del terrorismo de Estado constituye, afortunadamente, uno de los sustentos de la actual democracia argentina".

No obstante lo señalado, en la Ciudad de Corrientes -como ocurre en otras partes del país-, se podían/pueden escuchar testimonios diferentes por parte de ciudadanos y ciudadanas que vivieron el período y hoy sostienen que la última dictadura militar representó para ellos "el mejor periodo de su vida" y que, incluso, desean el regreso de los militares al poder. Ante esta divergencia de posturas con respecto al período militar nacen las inquietudes inspiradoras de este trabajo, pero desde su entretejido con la actualidad y las posibilidades que este habilita para el futuro, en cuanto existen franjas de la población que abogan por un nuevo gobierno militar. Consideramos que comenzar a indagar en la temática de los testimonios no condenatorios, que reivindican gobiernos militares, posee la importancia de advertirnos acerca de la existencia en la sociedad de fuertes cuestionamientos a la democracia como sistema de gobierno, situación que puede conformar la base social sobre la cual se edifiquen nuevos gobiernos dictatoriales y violentos. Estudiar los imaginarios sociales sobre nuestro pasado reciente debe ayudarnos a prever futuras fracturas en la seguridad de la democracia como modo de vida.

En aquel momento, además, pudimos notar que hasta el momento había más interés por las memorias de quienes fueron víctimas de violaciones a los derechos humanos, lo cual es sumamente importante, pero no obstante a ello, consideramos necesario estudiar las distintas experiencias y memorias de aquellas personas que nos decían/dicen que la dictadura fue el mejor periodo de sus vidas, sobre todo porque son estos discursos los que, en el futuro, podrían habilitar nuevos gobiernos autoritarios.

Fue entonces, cuando comenzamos a preguntarnos ¿cuáles son los imaginarios sociales que componen los testimonios no condenatorios -entendidos como memorias colectivas- hacia la última dictadura militar por parte de ciudadanas y ciudadanos que vivieron el período en la Ciudad de Corrientes?

La categoría de "imaginarios sociales" es tomada de Baczko (1991) y hace referencia al esquema de interpretaciones y valores, que moldea las conductas, los recuerdos, las formas de pensar y de sentir, y las esperanzas relacionadas con el futuro, por parte de un grupo social en un determinado tiempo y espacio. Por otra parte, Baczko (1991) realiza una relación entre 
imaginarios sociales y memoria colectiva, postulando que el dispositivo imaginario asegura a los grupos sociales esquemas colectivos de interpretación de las experiencias individuales tan complejas como variadas en el crisol de una memoria colectiva, de los recuerdos y de las representaciones del pasado cercano o lejano. La potencia unificadora de los imaginarios está asegurada por la fusión entre verdad y normatividad, informaciones y valores. Su trabajo se efectúa a través de series de oposición que estructuran la vida colectiva: "legitimar/invalidad, justificar/acusar, asegurar/desasegurar, incluir/excluir. Tal es así que los imaginarios sociales intervienen activamente en la memoria colectiva para la cual los acontecimientos cuentan menos que las representaciones (Portelli, 2016).

Los estudios enmarcados en la historia reciente toman a las memorias colectivas como una fuente de análisis. Pero: ¿qué son las memorias colectivas? Según Enzo Traverso: "el recuerdo del pasado se transforma en memoria colectiva una vez que ha sido seleccionado y reinterpretado según las sensibilidades culturales, las interrogaciones éticas y las conveniencias políticas del presente." (Traverso, 2007, pág. 68-72). Paralelamente a estas nociones, definimos a la memoria colectiva como la matriz social dentro de la cual se ubican los recuerdos individuales, porque se recuerda con imaginarios sociales compartidos, aun cuando las experiencias vividas durante la última dictadura militar sean únicas para cada persona. Los imaginarios sociales, a su vez, se hallan encuadrados en "marcos sociales" (Halbwachs, 1992); no obstante, no buscamos analizar el comportamiento de un determinado grupo social sino más bien describir las recurrencias presentes en los testimonios, en cuanto consideramos que este es el primer paso para futuros estudios más complejos acerca de la temática.

Los Testimonios No Condenatorios -categoría creada en la presente investigación- hacen referencia a un conjunto de reivindicaciones y justificaciones hacia el gobierno militar que hoy se pueden escuchar por parte de ciudadanas y ciudadanos que vivieron el período dictatorial en su juventud. Desarrollar en qué consisten estas reivindicaciones y justificaciones, cuáles son los imaginarios sociales que los conforman, será el objetivo del presente trabajo.

El interés por trabajar con los TNC hacia la última dictadura militar, no representa una cuestión aislada del contexto político actual y, sobre todo, futuro; en cuanto advertimos una existencia marcada de valores antidemocráticos que, vistos desde un contexto mundial, está posibilitando -quizás- una base de apoyo para nuevos gobiernos autoritarios que fogonean el desmedro hacia los derechos humanos. 
Las entrevistas a personas que expresaron TNC se realizaron entre los años 2012 y 2015 , cuando los medios de comunicación no ponderaban -al menos en términos generales- una lógica "pro-militar", mientras que durante el presente año -2019- se pueden observar a nivel mundial un pronunciado giro a la derecha con el advenimiento de gobiernos como el de Donald Trump en Estados Unidos y el de Jair Bolsonaro en Brasil -por solo citar algunos-, cuyos discursos fueron y son avalados por la ciudadanía, en cuanto su ascenso al poder ha sido por medio de elecciones. Paralelamente a ello, también se puede observar, también a nivel mundial, el resurgimiento de grupos "neofascistas", dentro del seno social.

En cuanto al trabajo de campo, en total fueron tomadas 53 entrevistas de las 96 realizadas, en cuanto fueron 53 en las cuales se expresaron TNC. Las entrevistas fueron en profundidad y no estructuradas, realizadas durante los años 2012-2015, en la Ciudad de Corrientes, específicamente se trabajaron en dos barrios: uno fue el barrio suburbano "17 de agosto" y el otro barrio fue el "Barrio Histórico", ubicado en el casco urbano de la ciudad. Las entrevistas fueron llevadas a cabo en las viviendas personales de los entrevistados y entrevistadas. Todos ellos/as tienen en común: haber vivido el gobierno militar en la Ciudad de Corrientes entre sus 15 y 25 años de edad, expresar TNC hacia dicho gobierno y no haber pertenecido a las fuerzas armadas, lo cual, consideramos, hubiera definido anticipadamente una postura positiva al respecto al gobierno militar. Cabe destacar que al mencionar estos porcentajes no buscamos posicionarnos en el método cuantitativo de las Ciencias Sociales, por el simple hecho que la realización de 96 entrevistas dista mucho de ser una proporción representativa del más de un millón de ciudadanas/os correntinas/os capitalinas/os, el objetivo es más bien rico en términos cualitativos en cuanto se pregunta por imaginarios sociales.

Para determinar el número de entrevistas se siguió el criterio de saturación conceptual (Strauss y Corbin, 2002). La forma en la que localizamos a nuestras/os entrevistadas/os fue a través de la técnica "bola de nieve". Formaron parte de la muestra intencional correntinas/os que vivieron el período militar y que sostienen Testimonios No Condenatorios hacia la última dictadura militar argentina y que pertenecen a diferentes clases sociales.

A partir del texto de las entrevistas desgrabadas, procedimos a detectar, por un lado, la presencia de testimonios no condenatorios "de reivindicación explícita" del gobierno militar, posicionando a la democracia como un pésimo régimen político y hasta expresando el deseo de un nuevo gobierno militar; y, por otro lado, testimonios no condenatorios "de reivindicación implícita", en cuanto ponderan algunos aspectos del gobierno militar, pero dicen "preferir/valorar la democracia a pesar de todos sus defectos". 
En el marco de los testimonios no condenatorios, tanto de "reivindicación explícita" como de "reivindicación implícita", describiremos las dimensiones de análisis presentes en el universo de significados de las/os entrevistadas/os. Cabe destacar que para establecer las dimensiones de análisis no se partió a priori con supuestos, de modo contrario, fueron surgiendo durante de entrevistas, ellas son: saberes acerca de las causas del golpe de Estado de 1976 y de lo que sucedía en la Argentina durante el período, valorizaciones acerca del rol del gobierno, del ciudadano, y las emociones asociadas a experiencias personales. Estas fueron las cuatro direcciones que tomaban las entrevistas a la hora de escucharse cuáles eran las reivindicaciones hacia el gobierno militar, de estas dimensiones extrajimos los imaginarios sociales.

Con respecto al sujeto de estudio, tampoco se seleccionó uno a priori, puesto que el objeto de estudio -Testimonios No Condenatorios- es el foco de investigación y quienes los sostienen no se hallan determinados o situados por/en una clase social específica ni por una institución social determinada, como ser, por ejemplo, la Iglesia Católica o un partido político puntual. Los Testimonios No Condenatorios, con diferencias discursivas, se hallan en los barrios suburbanos como en el centro de la ciudad, entre personas universitarias y no universitarias, entre ciudadanas/os con ingresos económicos altos como entre ciudadanas/os con escasos ingresos; con diferentes matices, con vocabularios diferentes, pero con representaciones sociales similares.

Consideramos que estos imaginarios sociales componen un tipo de memorias colectivas y, si bien, no podemos utilizarlas para explicar el consenso social con el cual contó la toma del poder por parte de los militares en la década del setenta, porque la memoria nunca es estática, al menos proponemos abrir este camino para analizar cuáles son las cuestiones culturales presentes en los ciudadanos que habilitan gobiernos represivos, basándose en experiencias del pasado y reivindicando opiniones tan antagónicas a la política de memoria estatal llevada a cabo por los gobiernos Kirchneristas durante doce años. ¿Por qué decimos "cuestiones culturales"? porque las representaciones sociales son entendidas como significativas en un entramado cultural específico y son duraderas.

La especificidad que adquiere nuestro objeto de estudio, por tratarse de un análisis de memorias, pero también de historia, provoca que nuestro "tiempo de estudio" oscile entre el presente, entendido como los años 2012-2015, período en el cual se llevaron a cabo las entrevistas, y los años de la década del setenta. Asimismo, las memorias colectivas analizadas en las entrevistas 
tienden a atravesar, por su propia condición, diferentes temporalidades, mezclando nociones y sentimientos del pasado con las del presente.

Por su parte, las entrevistas forman parte de las fuentes orales que, en palabras de Portelli (2016), son diferentes a las tradicionales en cuanto su capacidad de información no radica tanto en los acontecimientos, sino en sus significados. Esto no postula que los primeros no sean importantes ni tomadas en cuenta, sino que las fuentes orales imponen a la historia la subjetividad del actor. Informan no solo los hechos, sino lo que estos significaron para quienes lo vivieron y relatan. En estas narraciones se expresa la subjetividad del narrador dentro de la subjetividad de clase. "El interés en el testimonio no consiste solo en su adhesión a los hechos sino en su alejamiento de ellos, porque en este desvío se insinúa la imaginación, lo simbólico y el deseo" (Portelli, 2016, pág. 23-24).

¿Por qué Corrientes? La elección de la Ciudad Capital de la provincia de Corrientes se debió a tres motivos. El primero se debe al hecho de que quien investiga vivía allí y eso facilitaba el contacto personal con el primer grupo de personas que coincidían con las características buscadas en las/os entrevistadas/os. En segundo lugar, existen escasos escritos sobre el periodo militar en la provincia de Corrientes, mientras que consideramos necesario sumar las voces de las provincias a la historia de la última dictadura, en cuanto prevalecen abordajes de mirada "nacional" que proyectan desde una mirada bonaerense o porteña una narración que muchas veces no representa lo sucedido en otros puntos geográficos del país. En palabras de Franco (2012): "sin un trabajo largo de investigación (...) sobre los procesos en diversos niveles de la vida política nacional, provincial y local, (...) que pueda pensar la compleja articulación entre continuidades relativas y cambios sustantivos aun estamos lejos de entender el terrorismo de Estado". Y, en tercer lugar, debemos destacar que la Ciudad de Corrientes, a diferencia de otras ciudades de la provincia, se caracterizó históricamente por ser una "ciudad universitaria", lo cual le otorgó dinamismo social, la presencia de jóvenes de toda la provincia y la base para que allí también existiera la presencia de un activismo de izquierda más pronunciado. En Corrientes Capital existieron agrupaciones estudiantiles radicalizadas tales como: "el TUPAC, M15M, JUP, Montoneros, FAR, FAL, ERP, además de otras organizaciones políticas como el MSTM" (Zarrabeitia, 2010). Como así también, un centro clandestino de detención: el Regimiento de Infantería 9.

1. El presente trabajo de investigación está compuesto por seis capítulos. En el capítulo número uno nos abocaremos a desarrollar cual fue el camino metodológico y las técnicas utilizadas para el desarrollo de la investigación; asimismo describimos cuáles 
son las categorías de análisis sobre las cuales se edifica el trabajo desarrollado. En el segundo capítulo abordaremos el contexto histórico dictatorial, ahondando en la relación que existió entre "dictadura y sociedad", según diversos autores argentinos, para, finalmente, detallar las características del período en la Ciudad de Corrientes. El tercer capítulo abarcará un estudio del arte, retomando los trabajos de escritores que se hayan acercado a nuestro objeto de estudio, describiendo sus hallazgos y posicionándonos las líneas que seguiremos en contraste a estas investigaciones disponibles. En el cuarto capítulo se presentarán los resultados de nuestra investigación, hallados tras el estudio de las entrevistas. En dicho apartado se desarrollará la definición de testimonios no condenatorios y se caracterizarán las dimensiones implicadas en el estudio, para ello se dividirán los testimonios de "reivindicación explícita" y en testimonios de "reivindicación implícita", para luego describir las conexiones que las/os entrevistadas/os realizan entre el pasado y el presente, dividiendo los testimonios en cuatro aspectos: 1. Narrativas de lo sucedido: conocimientos sobre las causas de la toma del poder por parte de los militares en 1976 y explicaciones acerca de qué sucedía en el país. 2. Ideales de ciudadana/o. 3. Ideales de gobierno. 4. Experiencias personales durante el gobierno militar. Cada una de estas dimensiones están compuestas por imaginarios sociales recurrentes, los cuales serán descriptos. El quinto capítulo, se compararán las políticas estatales de construcción de la memoria correspondiente al período kirchnerista y los testimonios no condenatorios presentes en nuestras entrevistas. En el último capítulo, el sexto, desarrollaremos una síntesis que abarcará, en un todo integrado, cada uno de los capítulos, para establecer hallazgos y vacancias que nos dejó la investigación desarrollada. 


\section{Capítulo I}

\section{Cuestiones metodológicas y marco teórico}

\section{Cuestiones metodológicas}

Los Testimonios No Condenatorios hacia la última dictadura militar en la Argentina, conforman un recorte, puesto que consiste en una variable de "memorias colectivas" que coexisten con los testimonios condenatorios -otro tipo de memorias-. Asimismo, entendemos a las memorias colectivas como contenedoras de imaginarios sociales, sobre todo los imaginarios políticos/culturales.

Los Testimonios No Condenatorios hacia el gobierno militar de 1976-83, fueron pronunciados por parte de hombres y mujeres, de diferentes profesiones, que vivenciaron dicho período en la Ciudad de Corrientes durante su juventud -entre los 15 y 25 años de edad, aproximadamente- recordando principalmente en la actualidad aspectos considerados por sí mismos como "buenos" y justificando el accionar de las fuerzas armadas y de seguridad e inclusive, en ciertos casos, expresando el deseo de que los militares vuelvan al poder. Cabe destacar que las personas entrevistadas no ocuparon cargos públicos o gubernamentales durante el período militar, en cuanto existen trabajos de investigación sobre historia local ${ }^{2}$ los cuales sostienen que para "el caso de las burocracias provinciales y municipales se ha constatado que buena parte de los cargos directivos fue ocupada por personas que, sin adscribirse al régimen, encontraron en el contexto dictatorial una oportunidad de ascenso laboral (Lvovich, 2008).

Este objeto de estudio se relaciona con los estudios de memorias, porque las entrevistas, si bien versan sobre acontecimientos del pasado, son discursos emitidos en el presente (años 2012 hasta finales del año 2015). Dentro de los estudios edificados en el contexto disciplinar de Historia y Memoria, "se retoman las aproximaciones historiográficas que adoptan a los imaginarios sociales como un objeto privilegiado, lo cual habilita la construcción de una historia de las memorias (Sorgentini, 2003)."

\footnotetext{
${ }^{2}$ Soprano, G. y Bohoslavsky, E (comps), "Funcionarios e instituciones estatales en Argentina (de 1880 a la actualidad), UNGS, Buenos Aires, 2009.
} 
En otro orden de cuestiones, el concepto "Testimonios No Condenatorios", consiste no solo en una construcción teórica, sino también en una empírica. Está construida con base en un trabajo de investigación anterior, desarrollado en el año 2014, en el contexto de una carrera de grado. Este primer acercamiento al tema fue el que nos permitió detectar, en la Ciudad de Corrientes, una constelación de testimonios que se dirigían hacia la deslegitimación de la democracia. Es decir, se presentan en contradicción con la idea según la cual "la memoria de los horrores del terrorismo de Estado constituye uno de los sustentos de la actual democracia (Lvovich, 2008).”

Adentrándonos, finalmente, en el resultado de las entrevistas y, a pesar de utilizar el método cualitativo de investigación, nos resultó interesante exponer algunas cifras porcentuales para poder apreciar, de modo general, los resultados; reiterando y rescatando que la muestra teórica es no probabilística (Vieytes, 2004), en cuanto no se estableció de antemano un número de unidades a seleccionar, sino que estuvo guiada por la teoría emergente que se va construyendo a partir del criterio de saturación conceptual (Strauss y Corbin, 2002). En otros términos, si bien el haber trabajado con estos testimonios no nos posiciona en un trabajo cuantitativo -en cuanto el número de 96 personas entrevistadas para esta investigación dista mucho de ser una proporción representativa del más de un millón de ciudadanas/os correntinas/os capitalinas/os- es, en cambio, rico en cuanto a términos cualitativos.

Aclarada la cuestión metodológica, pasamos a las cifras que son resultado de esta investigación: de un total de 96 correntinos y correntinas capitalinos/as entrevistados/as, 53 personas han sostenido Testimonios No Condenatorios hacia el último gobierno militar de Argentina, transcurrido entre los años 1976-1983; es decir, el 55\% de las entrevistas se caracterizan por expresar TNC. No obstante, este grupo, a su vez, se halla dividido en dos tipos de TNC: por un lado, los Testimonios No Condenatorios de "reivindicación explícita" y, por otro lado, los Testimonios No Condenatorios de "reivindicación implícita".

$\checkmark$ De las 53 personas que expresaron TNC, 25 de ellas lo hicieron de manera explícita"; esto hace referencia a que el 26\% de las entrevistadas y los entrevistados, han señalado que, de hecho, prefieren un gobierno militar a uno democrático, señalando que el gobierno militar fue "el mejor período de sus vidas" y que "desean el regreso de los militares al poder".

$\checkmark$ Conjuntamente, 28 personas expresaron TNC de "reivindicación implícita"; es decir, el 29\% de las entrevistadas y los entrevistados, señalaron cuestiones positivas del gobierno militar 
y cuestiones negativas de la democracia como régimen político, no obstante, finalmente expresaron preferir la democracia. A causa de estas expresiones contradictorias, se denominó a este grupo de testimonios como de "reivindicación implícita".

$\checkmark$ Finalmente, y en contraposición, se hallan los Testimonios Condenatorios hacia el gobierno militar, los cuales se caracterizan por un discurso de absoluto rechazo hacia todas las medidas tomadas por dicho gobierno y por profundas críticas, de diversa índole, al período. Este grupo de entrevistas estuvo compuesto por el $45 \%$ de las entrevistadas y de los entrevistados, es decir por 47 personas. Este grupo de testimonios no serán indagados en profundidad en esta instancia de investigación, por no constituir el objeto de estudio específico.

Los TNC son las unidades de Análisis de la investigación. No obstante, no se seleccionó un grupo social específico (como ser: docentes, estudiantes, etc.) porque el eje central de la investigación fueron los TNC, "quiénes lo sostienen y el por qué", es un hallazgo obtenido como consecuencia de las entrevistas.

El 55\% de las personas entrevistadas, quienes expresaron TNC, está compuesto por empleados de comercio, comerciantes, amas de casa, profesionales universitarios -abogados, arquitectos, médicos, veterinarios-, ex peones rurales, empleadas domésticas y docentes de nivel primario y secundario. Es decir, podemos hallar líneas trasversales que atraviesan los discursos de diferentes clases sociales en el momento en que hablamos de testimonios no condenatorios hacia el último gobierno militar. No obstante, podemos especificar que el universo de personas entrevistadas está conformado por vecinas y vecinos de dos barrios de la capital correntina: uno fue el barrio suburbano "17 de agosto" y el otro barrio fue el "Barrio Histórico", ubicado en el casco urbano de la ciudad, que fueron jóvenes durante la última dictadura militar, que no fueron víctimas directas del terrorismo de Estado ni pertenecieron/pertenecen a las fuerzas armadas ni policiales. En el momento de realización de las entrevistas, las personas que brindaron su testimonio tenían entre 55 y 65 años, aproximadamente.

Una vez presentados los números generales que arroja nuestra investigación, a continuación, nos abocaremos a describir las diferentes dimensiones que fueron transversales en los discursos de las 96 personas entrevistadas en la Ciudad de Corrientes. Cabe destacar que dichas entrevistas se 
realizaron entre los años 2012 y finales del 2015; es decir, cuando aún persistía un discurso público claro, por parte del gobierno nacional, de deslegitimación hacia el período militar. Del mismo modo, resta aclarar que las dimensiones de análisis que presentaremos han surgido del propio trabajo de campo, como semejanzas que atravesaron los diferentes discursos, y no de modo apriorístico.

Las experiencias y los imaginarios sociales que componen los testimonios no condenatorios actuales hacia la última dictadura militar, por parte de ciudadanas/os correntinas/os que vivieron el período, han sido divididos de la siguiente manera:

2. Narrativas de lo sucedido: conocimientos sobre las causas de la toma del poder por parte de los militares en 1976 y explicaciones acerca de qué sucedía en el país. Esta dimensión se relaciona con el tipo de información que se posee sobre el período militar -académica, reflexiva, irreflexiva, inexistente, confusa, extensa, limitada, etc.- y con el rol de los medios de comunicación, indagando en las fuentes de información escrita que las y los entrevistados conocieron en la década del setenta.

3. Ideales de ciudadana/o. Esta dimensión de análisis se pregunta por aquellas nociones, valorizaciones y opiniones que poseen acerca del rol que debe cumplir una/un ciudadana/o, qué es valorado como adecuado/inadecuado, fructífero/intrascendente, normal/anormal, coherente/incoherente, entre otras cuestiones.

4. Ideales de gobierno. Esta dimensión alude a las ideologías (formación doctrinal), percepciones, valores, concepciones e información que poseen acerca del gobierno y su rol, de las jerarquías. También hace referencia a las actitudes políticas, tales como las posturas y las disposiciones -provocativa, reflexiva, pasiva, indiferente, comprometida, entre otras-.

5. Experiencias personales durante el gobierno militar. Esta dimensión indaga en las experiencias vividas durante el periodo militar, las experiencias violentas y las modificaciones y/o continuidades en su vida cotidiana. 
El objeto de estudio son los Testimonios No Condenatorios hacia el gobierno militar de 1976-83; no obstante, la temporalidad presente en las entrevistas no están limitadas por estas fechas precisas, más bien oscilan desde períodos de tiempo anteriores a 1976, hasta los tiempos presentes; de igual forma, las entrevistas se realizaron de manera desestructurada, pidiendo que se relaten sus experiencias vividas en dicho período, sin que exista una interrupción por parte de la entrevistadora, de este modo las nociones, el "sentido común" y las representaciones fluyeron libremente. Las intervenciones de la entrevistadora únicamente se realizaron en contemplación a la vida cotidiana de las/os entrevistadas/os y más que una guía de preguntas se trató de una guía de temas que fueron construidas en las primeras entrevistas, contemplando los marcos de referencia de los entrevistados; a modo de ejemplo podemos citar las siguientes preguntas guía: “¿cómo era su vida cotidiana durante la época de los militares?”, “¿cambió su vida cuando asumieron los militares al poder?”, “¿por qué motivo cree que los militares asumieron el gobierno?”, “qué hechos recuerda de aquel tiempo, vivió o se enteró de hechos de violencia?”, “¿quiénes eran las personas perseguidas por los militares?, ¿se hablaba de política en ese entonces en la familia o en el trabajo?, ¿conoció a alguna persona detenida y/o desaparecida?, ¿Qué medios de comunicación eran comunes en ese tiempo, qué noticias recuerda haber escuchado?, entre otras preguntas que variaban según los relatos de cada entrevistado y de los temas que agregaban independientemente. Cabe destacar que estas preguntas fueron disparadores, temas que se sumaron a lo largo de las entrevistas a causa de ser tratados por muchos/as entrevistados/as, al punto de convertirse en dimensiones de análisis.

La decisión de no interrumpir a la persona entrevistada y utilizar las preguntas señaladas anteriormente, cuando éstos llegaban a un punto de silencio, tenía como objetivo evitar que la/el entrevistada/o supiera cual era el tema sobre el cual se quería indagar -Testimonios No Condenatorios-. Esta técnica es la que Rosana Guber denominó: “atención flotante” (Guber, 2013). Estas maneras de llevar a cabo las entrevistas se explican por la necesidad de no dirigir respuestas, de no obligar a mentir a los entrevistados y evitar situaciones incómodas, considerando que, muchas veces, se demostró cierto "temor" a ser entrevistado sobre "la época de los militares", al punto de solicitar, en un gran porcentaje, que sus nombres y apellidos se mantengan en el anonimato. Asimismo, en muchas ocasiones las personas accedían porque quienes intercedían por la entrevistadora eran personas de confianza para ellas. Del mismo modo, la desconfianza al 
momento de iniciar las entrevistas se vio plasmada cuando reiteradamente los entrevistados y entrevistadas preguntaban cuestiones tales como: "quiénes querían saber", y excusaban barreras tales como "yo no me acuerdo de nada" o "yo no sé nada", barrera que se lograba salvar al explicárseles que "solo se quería saber sobre la vida cotidiana de aquel tiempo"; con estas simples aclaraciones se lograba romper la situación tensa, ya que afloraban recuerdos del pasado, de familiares, de la juventud y, de manera natural, a las anécdotas se iban asociando opiniones políticas, conocimientos, indignaciones, valorizaciones, preocupaciones, enojos, tristezas, creencias, etcétera. No obstante, aun así, muchas de las personas entrevistadas solicitaron mantener sus nombres en el anonimato, quizás por miedo a ser juzgadas/os, ya que en reiteradas ocasiones sostenían que "deseaban que vuelvan los militares, aunque suene mal decirlo ahora", con esto último se referían a que en ese momento se hallaba en la presidencia Cristina Fernández de Kirchner.

Consideramos que haber trabajado de esta manera, indagando en lo afectivo, en el "sentido común" en los saberes, valores y emociones, fue determinante a la hora de construir categorías sociales, imaginarios sociales para así lograr dar cuenta cómo se componen y fundamentan por parte de los sujetos los Testimonios No Condenatorios.

Las técnicas de construcción de datos fueron las entrevistas no estructuradas (Alonso, 1998) y semiestructuradas en profundidad. Con respecto a las estrategias de análisis de datos, se utilizó el software de análisis cualitativo “Atlas. Ti”. Los datos obtenidos fueron comparados entre sí y desde las teorías contempladas en el marco teórico. El último paso, fue la elaboración de una descripción de los Testimonios No Condenatorios hacia la Última Dictadura Militar en la Ciudad de Corrientes.

Finalmente, debemos advertir sobre nuestro objeto de estudio: los imaginarios sociales. Si bien la memoria no resulta ser una fuente completamente fidedigna de los acontecimientos y hechos del pasado, puesto que está atravesada por miedos, olvidos, confusiones, modificaciones por el paso del tiempo, lo cual podría entenderse como una limitación, adoptamos la postula de Portelli cuando señala que la importancia del testimonio no reside tanto en su "adhesión al hecho" como en su alejamiento del mismo, cuando afloran el simbolismo, la imaginación y el deseo. En este caso, las fuentes orales permiten no sólo la reconstrucción de hechos del pasado, sino también, mucho más 
significativamente, el acceso a las subjetividades y experiencias que, de otro modo, serían inaccesibles al investigador (Portelli, 1991).

Nuestra investigación, al inmiscuirse en las memorias colectivas, no pretende conocer si los hechos relatados fueron reales o si son ficticios, sino que el objetivo es describir los imaginarios sociales que podrían constituir un llamado de atención ante posibles/futuros acontecimientos políticos. El objetivo no es sonar "alarmista", sino más bien señalar la existencia de discursos que pueden ser peligrosos para la democracia, en cuanto no es posible asegurar taxativamente que los gobiernos autoritarios son cuestiones del pasado ya superadas. Si podemos sostener que el golpe militar de 1976 fue aceptado por grandes grupos de la sociedad, quienes brindaron su apoyo de diversas maneras que oscilan entre el silencio hasta el acompañamiento económico y logístico, ¿por qué no advertir acerca de discursos presentes en la sociedad que cuestionan tanto la democracia como el respeto a los derechos humanos y abogan por un nuevo gobierno militar?

Marco teórico: la especificidad del trabajo con memorias sobre la última dictadura

Los testimonios no condenatorios hacia el último gobierno militar constituyen un tipo de memoria colectiva, la cual está constituida por imaginarios sociales. Los imaginarios sociales que evocamos tienen relación con un esquema cultural de interpretación política que perdura en el tiempo y que está constituido por un conjunto de representaciones acerca del rol del gobierno, del ciudadano, de orden, desorden, de lo legítimo, entre otras cuestiones; en un proceso constante de retroalimentación.

Con respecto al término "Testimonios", tomamos en consideración las definiciones propuestas por Jelín (2002), quien los define como "construcciones de memorias, que implica multiplicidad de voces, circulación de múltiples "verdades" y también múltiples silencios y cosas no dichas." Paralelamente a esta definición, Levín (2005), señala que "los testimonios son discursos, en tanto pueden ser interpelados para analizar tanto las vivencias, experiencias y representaciones que componen la memoria individual, como la denominada memoria colectiva." 
Estudiar las "secuelas" culturales de la última dictadura militar puede tornarse muy interesante si comenzamos a detenernos en lo que la sociedad recuerda y, sobre todo, en lo que estaría dispuesta a legitimar o relegitimar. El período militar que se inició en 1976 mediante un golpe de Estado contó con cierta complicidad de la población, "Los golpes de estado vienen de la sociedad y van hacia ella, la sociedad no es un genio maligno que los gesta ni tampoco su víctima indefensa." (Calveiro, 1998). Es por estos motivos que nos interesa indagar la manera en la cual, tras varios años de democracia, hay ciertos discursos que continúan anhelando una dictadura militar. En palabras de Rosana Guber, tomar en consideración los imaginarios sociales es importante en cuanto:

"Así como la realidad social es determinante y a la vez determinada por la práctica de los actores, una explicación no reduccionista necesita incorporar esas nociones de los actores y no definirlas ex ante desde la teoría." (Guber, 2013)

En dichos imaginarios nos encontramos con valores, visiones de mundo, experiencias personales, conocimientos, opiniones, etc. Los imaginarios sociales intervienen en la memoria colectiva al punto en que éstos cuentan con más importancia que los propios acontecimientos. Finalmente, preguntarse por los imaginarios sociales es preguntarse por los significados que los sujetos poseen para interpretar los acontecimientos que se hayan en su experiencia y de la trama cultural que subyace a las clases sociales en cuanto representaciones sobre el ideal de ciudadano y el ideal de gobierno.

No obstante, no resulta factible o científico realizar entrevistas orales en la actualidad para intentar conocer qué pensaban las/os ciudadanas/os durante la década del setenta, considerando que "la memoria se declina siempre en presente y éste determina sus modalidades: la selección de acontecimientos que el recuerdo debe guardar, su lectura, sus lecciones, etc." (Traverso, 2007). En otros términos, sólo podemos conocer las memorias colectivas actuales sobre el período pasado. A su vez, los relatos no resultarían un reflejo fiel de lo que fue la realidad dictatorial, la memoria está compuesta por un conjunto de creencias, ritos y normas que representan las "leyes" identitarias de un colectivo específico, lo que Yerushalmi (1989) denominó "anamnesis". No obstante, "la noción de memoria nos permite trazar un puente, una articulación entre lo íntimo y lo público" (Franco y Levín, 2007). 
Por todo lo descripto anteriormente, el presente trabajo se edifica sobre la propuesta de ponderar cuáles son las memorias colectivas actuales y su postura ante la toma del poder político por parte de las fuerzas armadas en 1976. Pero aquí surge de modo paralelo otra cuestión a tener en cuenta: cada región de la Argentina puede presentar diferencias; se torna necesario, por tal motivo, desarrollar estudios que consideren las especificidades y las diferentes memorias colectivas. Nuestro trabajo tiene la especificidad de tomar a la Ciudad de Corrientes como recorte geográfico.

Para definir "memorias colectivas", se parte de su fundador Halbwachs (2011), para quien la memoria se conecta con los sentidos del presente y trasciende a los individuos. Este autor nos propone pensar la memoria individual en "marcos sociales", los cuales hacen referencia al conjunto de representaciones, necesidades, valores y visiones de mundo de una sociedad o grupo social en un momento y lugar determinado. Para Halbwachs siempre que recordamos lo hacemos con base en la memoria colectiva, a los códigos culturales compartidos. Esta característica convierte a la memoria en una constante reconstrucción social, puesto que los recuerdos se construyen con los demás y no de manera solitaria.

Para completar el concepto de memoria colectiva de Halbwachs y llevarla a la óptica política que se propone, retomaremos a la socióloga argentina Jelín (2002), quien incita a reconocer a las memorias como objeto de disputas, conflictos y luchas entre actores enmarcados en relaciones de poder desiguales, en cuyos discursos se pueden rastrear presencias y sentidos del pasado; para la autora, se torna necesario escapar del durkheinismo de Halbwachs y pensar la memoria desde posiciones más individuales. En relación a ello, distingue entre dos tipos: la "memoria habitual", aquella que sólo repite hábitos aprendidos socialmente y la "memoria narrativa", aquella que es producto de la manera en que el actor construye un sentido del pasado, mezclando lo subjetivo con lo construido socialmente. No obstante, Jelín nos hablará de las memorias de la dictadura tomando a aquellas que tienen relación con personas que vivieron hechos traumáticos, lo cual no se corresponde con nuestro sujeto de estudio. Más allá de esta especificidad, a modo general adoptamos su postura de entender a la memoria como una construcción individual y a la vez social, puesto que las vivencias individuales no se transforman en experiencias con sentido sin la presencia de discursos culturales (Jelín, 2002). La fusión entre ambos teóricos nos ayudó a elaborar la categoría central de este trabajo: los Testimonios No Condenatorios hacia la última dictadura militar en Argentina. 
finalmente, para “pulir" el enfoque de nuestra investigación, partiendo desde ideas generales, como las que nos representan Halbwachs y Jelín, y para arribar a una mirada más particular: los TNC, tomamos a Alessandro Portelli como referencia teórica. Portelli (2016), gran referente de la historia oral, "nos ofrece un ejemplo de las posibilidades de la historia oral para analizar memorias conflictivas que resuenan vívidamente en el presente". El autor narra testimonios y paralelamente advierte en ellos la forma en la cual las ideologías políticas influyen en "los recuerdos", abriéndose brechas entre "hechos" y "representaciones" que se basan en las subjetividades de las/os protagonistas. Asimismo, Portelli (2016) hace un contraste entre "la historia oficial" y las historias que se desenvuelven en contextos locales y/o en grupos sociales reducidos; y, si bien, los análisis de Portelli no se corresponden con Argentina sino más bien con Italia -su país de origen-, su estilo narrativo y su manera de contrastar la información nos inspiró para trabajar en la presente investigación.

\section{¿Cómo pensamos los imaginarios sociales?}

En cuanto a la categoría polisémica de "Imaginarios Sociales", se propone retomar la definición elaborada desde la disciplina de la Historia, por Bronislaw Baczko (1991). Baczko, historiador procedente de Polonia, si bien trabaja sobre temáticas correspondientes a la Edad Moderna, realiza un análisis acerca de cómo funcionan los imaginarios sociales y cuál es su relación con el poder político. No obstante, no nos enfocaremos en su misma perspectiva, puesto que el autor fija más su atención en la constitución de identidades nacionales, las cuales deben su origen, según él, a los imaginarios sociales construidos alrededor de mitos, utopías e ideologías, estudiando al mismo tiempo a los símbolos sobre los que se apoyan dichos imaginarios (Belinsky, 2007). Nuestro vértice será más bien el de imaginarios sociales relacionados con la política, pero en el contexto de la Historia Reciente, más precisamente con respecto a un gobierno en particular: el gobierno militar de 1976-1983, y definiendo contextos geográficos específicos, sin realizar generalizaciones.

Sirviéndonos de Baczko, podemos definir a los imaginarios sociales como un conjunto de representaciones que un grupo social tiene de sí mismo, de la manera "correcta" en que se deben distribuir las posiciones y los papeles sociales, creencias comunes acerca de cómo debe ser el 
gobierno, el ciudadano, quienes son los amigos, los enemigos, el orden y el desorden. El imaginario social, por ende, es una fuerza que regula la vida colectiva y el ejercicio del poder. Son las modalidades de pensar, creer y sentir que varían entre diversas sociedades y con el correr del tiempo. Este es el punto de encuentro con el autor, aunque nuestra fuente de estudio no sean los símbolos, como en su caso, sino los testimonios (Baczko, 1991).

Por otra parte, Baczko realiza una relación entre imaginarios sociales y memoria colectiva, postulando que el dispositivo imaginario asegura a los grupos sociales esquemas colectivos de interpretación de las experiencias individuales tan complejas como variadas en el crisol de una memoria colectiva, de los recuerdos y de las representaciones del pasado cercano o lejano. La potencia unificadora de los imaginarios está asegurada por la fusión entre verdad y normatividad, informaciones y valores. Su trabajo se efectúa a través de series de oposición que estructuran la vida colectiva: legitimar/invalidad, justificar/acusar, asegurar/desasegurar, incluir/excluir. 


\section{Capítulo II}

Contexto histórico: la relación "dictadura-sociedad" en la Argentina de la década del setenta

“El pasado cercano (...) no está hecho solo de representaciones $y$ discursos socialmente construidos y transmitidos, sino que, además, está alimentado de vivencias y recuerdos personales”. M. Franco y F. Levín (2007)

El tema investigado en este trabajo, "testimonios no condenatorios hacia la última dictadura militar", es congruente con el terrero historiográfico de la Historia Reciente, sobre todo aquella surgida en Argentina y en otros países del Cono Sur, institucionalizándose como objeto historiográfico muchos años antes en la historiografía occidental contemporánea (Europa y Estados Unidos), cuyos orígenes pueden rastrearse en las experiencias de la Primera y (sobre todo) de la Segunda Guerra Mundial (Franco y Levín, 2007). A la hora de establecer cuál es la especificidad de este campo de estudios, muchos historiadores concuerdan en que se edifica en la coetaneidad entre pasado y presente: la supervivencia de protagonistas del pasado que pueden brindar sus testimonios, la existencia de una memoria colectiva viva sobre ese pasado y el predominio de procesos sociales considerados traumáticos: guerras, masacres, genocidios, dictaduras entre otras situaciones extremas. Todo ello ha permitido repensar la importancia de los sujetos como "actores sociales", sus prácticas, experiencias y representaciones sociales, a través de la historia oral (Franco y Levín, 2007).

El tipo de relación entre Historia y Memoria escogida para este trabajo es aquella que ubica a la memoria como objeto de estudio de la Historia, lo cual se denomina, en Ciencias Sociales, "Historizar la memoria", a causa de que las significaciones de los hechos del pasado no son estáticas, sino que conforman luchas políticas en las cuales están imbricados los diversos actores sociales (Jelín, 2002). 
Con respecto a los textos que adoptan como enfoque de investigación a la relación de la sociedad con la dictadura, podemos distinguir en las obras académicas dos grandes vertientes explicativas (posiblemente existan vertientes diferentes, pero rescatamos estas dos por considerarlas las más representativas):

$\checkmark$ Aquellas que le asignan un rol más protagónico, al pensarla como "cómplice" del gobierno militar.

$\checkmark$ Aquellas que posicionan a la sociedad en un papel de víctima paralizada por el miedo.

En primer lugar, si bien a nivel internacional se desarrollaron muchos estudios en cuanto a la relación "sociedad-gobiernos autoritarios" (Gellately, 2002; Goldhagen, 1997), dichos estudios toman en consideración a los gobiernos totalitarios de Mussolini y Hitler; cuestión que presenta una diferencia fundamental con el caso argentino, puesto que la última Dictadura Militar Argentina no fue un gobierno totalitario, en el sentido de propiciar el apoyo de las masas -tomando como posible salvedad el mundial de futbol jugado en Argentina durante el período militar-.

Con respecto a la posición académica que versa acerca de las responsabilidades sociales que posibilitaron la instalación y prolongación de un gobierno militar en la década de 1970, contamos con autores cuyo posicionamiento piensa a la sociedad desde una postura del consenso hacia la dictadura. Siguiendo la conceptualización de Lvovich (2006), entendemos el término "consenso", como la "adhesión y el apoyo dado por los ciudadanos al sistema político, que se traduce (...) en la obediencia y disponibilidad de los mismos a aceptar las decisiones tomadas por los gobernantes. Este concepto nos permitiría dejar de lado a aquellas teorizaciones que señalan que no se puede hablar de consenso social en contexto de dictadura cuando existe un aparato que utiliza la fuerza física represiva.

Daniel Lvovich (2008), escribió acerca de las "actitudes sociales" de "la gente corriente" durante la última dictadura militar. Con respecto a estos términos hace referencia a que la dictadura, al menos en sus inicios, contó con un fuerte consenso social y no solo por parte del sector más concentrado del poder económico o por parte de la cúpula religiosa, sino también por amplios sectores sociales, los cuales son denominados por él como "la gente corriente". Este consenso social encuentra muchas explicaciones, entre las que el autor menciona que, ante la violencia y el caos económico presente en el gobierno de Isabel Perón, la sociedad depositó su esperanza en el gobierno militar para recuperar el orden. 
Esta vertiente tomará ideas como las de O’Donnell (1984), quien realizó, junto a su esposa Cecilia Galli, una serie de entrevistas durante el período dictatorial para luego compararlas con otras realizadas luego de la Guerra de Malvinas, recogiendo a través de los testimonios características sobre el consenso y la legitimación social que recibió el régimen, lo que él denomina "microdespotismos"; sin embargo, no lo hace definiendo un sujeto de estudio específico, sino entrevistando a personas de diversos sectores y actividades sociales. La conclusión principal a la que llegó O’Donnell (1984), señala que "no hubo sólo un gobierno brutalmente despótico, sino también una sociedad que durante esos años fue mucho más autoritaria y represiva que nunca, en los contextos cotidianos". Es decir, la sociedad, dentro de los contextos cotidianos ("micros") repitió el autoritarismo en las escuelas, en los hogares, en los lugares de trabajo, porque existía el convencimiento de que la "insolencia de los inferiores solo llevaba al caos". De este modo, la sociedad contribuyó enormemente a la normalización del autoritarismo estatal.

Dentro de esta misma vertiente podemos ubicar a Calveiro (1998), quien, desde las Ciencias Políticas, si bien realiza un estudio de lo que ella denomina los "campos de concentración" en la Argentina, habla del consenso social por parte de la sociedad argentina (no especifica un espacio geográfico específico) desde la perspectiva del silencio por la cual, según señala, la dictadura pudo actuar libremente. Según su análisis las personas eligieron no ver, no enterarse de lo que sucedía, la realidad era conocida, al menos "había indicios del poder desaparecedor", pero los "ciudadanos comunes" la negaba, no por encontrarse anonadada por el terror sino por pasividad ingenua. En palabras de Calveiro (1998): "sólo pueden existir campos de concentración en sociedades que eligen no ver".

Vezzetti (2009), es quien señala, desde su contexto geográfico que es Buenos Aires, que la dictadura tuvo sustento en la cultura argentina, en las representaciones políticas que estaban presentes en la sociedad desde tiempo atrás, el autor no negará la existencia de intereses ni eliminar la culpabilidad de los militares, sino que promueve el estudio de las responsabilidades sociales de la "gente corriente".

Por su parte, Marcos Novaro (2006) sostuvo que con matices que iban desde la adhesión expresa a los objetivos del "proceso" y la justificación de lo actuado ante la agresión subversiva, todos reconocían el esmero de los hombres de armas para recuperar el orden y la seguridad, y aclaraban que los "buenos argentinos" deseaban vivir en paz. 
Arribando a las teorizaciones de la segunda vertiente, la cual piensa a la sociedad desde el papel de "víctimas del miedo" en el período dictatorial, encontramos dos obras: desde el campo de la Sociología, Corradi (1996), introduce la noción de "cultura del miedo", para explicar los comportamientos sociales en el período dictatorial. Según el autor, el poder del terror tiene dos dimensiones: una de comportamientos y otra ideológica. La dimensión del comportamiento comprende la coerción física y la amenaza de ejercerla, y la dimensión simbólica se ejerce mediante sanciones simbólicas y materiales, con prácticas discursivas y económicas que logran generar una obediencia voluntaria.

Desde el campo de la Comunicación Social, Caviglia (2006), se pregunta cómo fue posible la instauración y, sobre todo, permanencia de la dictadura militar, en "qué sociedad", y resuelve la cuestión desde un estudio de la vida cotidiana de personas que ella considera como perteneciente a la clase media de la Ciudad de La Plata, que vivieron el período dictatorial sin pertenecer a las Fuerzas Armadas ni a las organizaciones armadas de izquierda. La técnica utilizada fueron entrevistas en profundidad y arribó a la conclusión de que la sociedad compuesta por "ciudadanos corrientes" estaba aterrorizada y silenciada por considerarse en peligro o impotente. Es decir, las condiciones y continuidades socio-culturales que, de múltiples maneras, hicieron posible el surgimiento, la implantación y las consecuencias de la última dictadura en Argentina se debían, en líneas generales, al miedo.

Existen, no obstante, algunas obras académicas que, si bien no toman al consenso social como objeto de estudio específico, arriban a conclusiones que las involucran y señalan algunas cuestiones que consideran sus causas. El estudio acerca de las relaciones entre sociedad y dictadura, desde el campo de la historia, cuenta con el trabajo de Marina Franco (2012), quien se peguntará “¿Cómo fue posible que la sociedad argentina llegara a los espirales de violencia que confluyeron en la Dictadura Militar?”. Esta autora colocará el foco de análisis en la imbricación histórica que se estableció entre las prácticas estatales de carácter autoritario y represivo y los discursos políticos y periodísticos porteños dominantes en el período que se extendió entre 1973 y 1976. Su obra deja entrever que una de las causas de la aceptación social de la dictadura consiste en la naturalización de la violencia generada por dicha imbricación, la cual será su objeto de estudio. Su contexto geográfico se ubica en la Ciudad de Buenos Aires. 
Dentro del contexto de la disciplina histórica, Águila (2008), analizará la dictadura militar en el ámbito de la Ciudad de Rosario, desde la perspectiva de las estrategias represivas desplegadas por la dictadura (el diseño de la represión) y su correlato con las actitudes sociales y las prácticas sociales de consenso y de resistencia, señalando diferentes fases por las que atravesó dicho correlato. En cuanto al consenso social, según la autora tuvo características y grados diferentes, señalando la dificultad de definir si representaban una adhesión consciente o inconsciente y propone más bien entender las actitudes sociales de conformidad o indiferencia hacia el régimen autoritario como resultado de, en algunos casos, temor a la represión y, en otros casos, una aceptación de las explicaciones provistas por los militares.

En esta misma vertiente hallamos a Florencia Levín (2005), quien realiza entrevistas a ciudadanas/os que vivían en los alrededores de los centros clandestinos de detención, para dar cuenta de las representaciones sociales que existen acerca de lo que allí sucedía y por qué. En cuanto a sus conclusiones, abre un abanico de explicaciones con respecto al papel un tanto indiferente de los entrevistados con respecto a lo que sucedía cerca de su hogar, explicaciones que oscilan entre el miedo y el consenso, adaptación y negación.

Desde el campo de la sociología, Carassai (2014), con una división de la sociedad en base a clases sociales, realiza un estudio sobre los años setenta, analizando lo que él denomina "la naturalización de la violencia en la clase media", a su vez dividida entre militantes políticos y no militantes, y tomando como sujeto de estudio a la clase media no militante (a la cual denomina “gente común”), entendida como aquella que no se involucró en política ni formaba parte de los grupos de poder, realizando de modo paralelo una lectura de la publicidad, la telenovela y el humorismo como medios de construcción de sentido común; sentido común visualizado en los testimonios de las personas que entrevistó y que él ubica en la clase media de la Ciudad de Buenos Aires, de San Miguel de Tucumán y el pueblo de Correa de la provincia de Santa Fe, Argentina. Sus conclusiones serán presentadas como una descripción de la clase media argentina, a la cual definirá como antiperonista, de tendencias políticas de centro-derecha, no la considera violenta ni pacifista, más bien postula que el abuso de la violencia durante la dictadura se debió a la violencia de los años precedentes, a pesar de que la violencia que se impugnaba era la de los insurgentes y no la ejercida desde el Estado. 
En relación a lo expuesto anteriormente, podemos notar que las/os autoras/es mencionadas/os realizaron interpretaciones acerca de la relación entre dictadura-sociedad, intentado brindar explicaciones sobre las posibles causas de un hecho fundamental: muchos grupos de la sociedad aceptaron pasivamente el golpe de Estado de 1976. Los por qué oscilan entre el miedo y la complicidad.

Existen, asimismo, prolíferas obras acerca de civiles e instituciones con poder que acompañaron a los militares en la toma del poder y durante los años de su gobierno, podemos citar con respecto de la relación entre la dictadura militar e iglesia católica a: Mignone (1986). Con respecto de la relación entre la dictadura militar y los partidos políticos podemos citar a: Quiroga (1994), entre otros. Sobre la relación que existió entre la dictadura militar y la prensa podemos citar a: Blaustein y Zubieta (1998), Schindel, Estela (2012), Ulamovsky (2005), Vitale (2015), entre otros. Acerca de la relación entre la dictadura militar y los empresarios podemos citar a: Pucciarelli (2004), entre otros. Sobre la relación entre sindicatos y la dictadura: Mason (2007), entre otros.

La semejanza entre las obras mencionadas radica en que todas ellas se preguntarán ¿cómo fue posible que haya sucedido el golpe militar? La diferencia es que las/os autoras/es mencionados en los primeros párrafos se preguntan por "las/os ciudadanas/os comunes" o "personas corrientes"; mientras que las/os autoras/es que mencionamos en el párrafo anterior, representan a poderes (civiles) tales como: la iglesia, la prensa, la escuela, los partidos políticos y el empresariado.

Mas allá de cuáles hayan sido las causas o explicaciones del acompañamiento civil que tuvieron los militares, tanto por parte de "las personas corrientes" como por parte de instituciones civiles, existen, en la actualidad, personas que no solo añoran los años de la dictadura, sino que, además, expresan su deseo de un nuevo gobierno militar. Esta es la línea que indagamos. Cómo, en el presente, cuando pareciera ser incuestionable la idea de que la democracia es la mejor forma de gobierno, se pueden escuchar argumentos a favor de un gobierno militar de facto, aún después de ser de público conocimiento las profundas violaciones a los derechos humanos que se realizaron durante la década del setenta. En el siguiente capítulo describiremos cuáles son los trabajos académicos existentes acerca de, lo que aquí denominamos, "testimonios no condenatorios actuales hacia la última dictadura militar en La Argentina”. 


\section{Capítulo III}

Estado del arte: "testimonios no condenatorios hacia la última dictadura militar" por parte de otras/os autoras/es

Relatos analizados por otros investigadores: grandes semejanzas con los TNC

Levín (2005), realizó un trabajo llamado: "Arqueología de la memoria. Algunas reflexiones a propósito de Los vecinos del horror." En él toma como fuente a un video independiente, realizado por trabajadores del ámbito de salud mental, en el año 1996. El video está compuesto por 10 testimonios de quienes fueron vecinos de centros de detención clandestinos del Gran Buenos Aires y de Capital Federal. Las personas entrevistadas son hombres y mujeres, cuya edad rondaba aproximadamente entre los 40 y los 75 años de edad y pertenecientes tanto a las clases populares como a sectores medios.

Levín señaló que en Argentina tiene un gran arraigo una memoria colectiva acerca del pasado reciente basada en la teoría de los dos demonios, la cual culpa a las cúpulas militares y a las cúpulas de las guerrillas de llevar a cabo una violencia que recayó injustamente sobre una sociedad que en su conjunto ignoraba lo que estaba sucediendo o no lo entendía, y que por lo tanto fue una víctima inocente de todo lo que sucedió. Levín cuestionará, sobre todo, esta caracterización de la sociedad alegando que se puede comprobar, a través de los testimonios del video, que la sociedad no era un sector inocente que ignoraba lo que sucedía. Si bien la autora admite que existió un rico y heterogéneo panorama de experiencias que hablan tanto del horror como del acomodamiento, de la angustia como del consentimiento, de la ignorancia como del conocimiento acerca de lo que sucedía en los campos de concentración emplazados en los barrios, no se puede seguir sosteniendo a la sociedad como una simple victima ignorante y pasiva, en sus palabras exactas: "Lo que estos testimonios nos muestran es que algo de la clandestinidad de los centros de tortura desbordaba y penetraba el barrio dejando rastros que eran percibidos por los vecinos tanto en forma visual como auditiva" (Levín, 2005). No obstante, cabe destacar la diferencia entre nuestro trabajo de investigación y el de Florencia. Florencia se pregunta por la "responsabilidad colectiva", es decir, 
por el rol de la sociedad durante la dictadura y, mediante los testimonios, elabora explicaciones acerca de lo que pudo haber sucedido en los años setenta, sobre todo en los barrios donde existían centros de detención clandestinos. Es decir, si bien advierte que el tiempo modifica las percepciones, utiliza los testimonios del video para interpretar cuestiones del pasado. Los testimonios del video revelan muchas y contundentes similitudes con los testimonios que recogimos en Corrientes para nuestra investigación, sin embargo, Levín los toma para revelar cuestiones que debieron existir en el pasado, específicamente el apoyo, la conformidad y los distintos grados de consenso social con que contó el régimen.

En sintonía con Florencia Levín, se halla Vanesa Garbero (2017), quien escribió un trabajo titulado: "El terrorismo de Estado en la Argentina a escala local, tensiones entre la memoria dominante y memorias locales. Vanesa también estudia los testimonios de habitantes de barrios aledaños a un ex centro clandestino de detención, pero en Córdoba. Y los utiliza para mostrar el contraste entre ellos y la teoría de los dos demonios, a la que considera como la memoria dominante en la actualidad del país. Garbero a entrevistó a mujeres y hombres que fueron jóvenes y/o adultos durante el período de la dictadura y que no fueron víctimas directas del terrorismo de Estado. En total su muestra es de 29 personas y su objeto de estudio son las memorias. Por otro lado, la autora señala la importancia del tiempo en la constitución de las memorias; es decir, al igual que en nuestro trabajo de investigación, Garbero estudia las memorias del presente y su análisis no busca interpretar al pasado. Asimismo, toma los testimonios para poner en tensión, a la memoria dominante sobre la dictadura, cuya descripción es tomada de Ludmila Da Silva Catela (2010), según la cual se trata de la memoria que domina el espacio público y la conforma un conjunto de elementos que pueden resumirse de la siguiente manera:

1. Limita una temporalidad que no puede traspasar la frontera de 1976-83.

2. Propone un relato para los sitios de memoria circunscripto a lo que fue y se entiende por terrorismo de estado.

3. Reconoce centralmente un tipo de víctima: los desaparecidos, dejando de lado o silenciando a otras víctimas como asesinados, exiliados, sobrevivientes.

4. Habla de la violación a los derechos humanos, haciendo un uso monopólico del término exclusivamente para enunciar el pasado reciente, más específicamente desde el 76-83. 
5. No deja espacio para el tema de la lucha armada, estigmatiza a los que sobrevivieron y a los que participaron en la acción política y armada en los años setenta.

Considerando esta definición de "memoria dominante" la cual se corresponde con los años kirchneristas, Garbero analiza los testimonios de sus entrevistas arribando a la conclusión de que no son esas las representaciones sociales locales, sino que éstas retoman sentidos permeados por la teoría de los dos demonios, en cuanto las entrevistas dejan ver: una equiparación de dos violencias enfrentadas (las fuerzas armadas y las guerrillas), la relación de acción/reacción entre las guerrillas y la violencia estatal, la equiparación entre estas dos violencias y la situación de exterioridad de la sociedad en ese conflicto. Este resultado, es decir: la presencia de la teoría de los dos demonios en la sociedad local, caracterizada por estos cuatro puntos, es muy similar a los resultados de nuestro trabajo. De esos mismos imaginarios sociales se componen nuestros Testimonios No Condenatorios. No obstante, se presentan tres diferencias entre el trabajo de esta autora y el nuestro. La primera tiene relación con lo que entiende la autora por "persistencia de la teoría de los dos demonios", en nuestra investigación se plantea una variante diferente, en cuanto nuestras entrevistas también presentan la variable de "la existencia de un solo demonio: la guerrilla". Otro punto fundamental de diferenciación consiste en el espacio geográfico, en cuanto Garbero entrevista a personas que vivieron en los alrededores de ex centro clandestino de detención, mientras que nuestras entrevistas no cuentan con esta caracterización. El único ex centro clandestino sobre el cual se conoce su existencia en la Ciudad de Corrientes, el Regimiento de Infantería 9, se encuentra en una ubicación alejada de hogares comunes, a un costado del puente Belgrano y hacia la costanera de la ciudad. Finalmente, Garbero hace su análisis teniendo en cuenta un aspecto específico: el terrorismo de Estado, su objetivo será indagar cuales son las representaciones sociales que poseen las personas entrevistadas, pero desde esta perspectiva particular. Nuestro trabajo, a diferencia de ello, se aboca a la descripción de los TNC.

"Rasgos de la cotidianidad en la 'época de los militares', representaciones de ex obreros que no estaban metidos en nada" es un trabajo realizado por Eleonora Bretal (2015), aborda las representaciones de 19 personas, hombres y mujeres, que fueron obreros del frigorífico Swift de la ciudad de Berisso, algunos fueron activistas sindicales -no de la dirigencia, sino de las bases-. Si bien su sujeto de estudio no es el mismo que el nuestro, al igual que el espacio geográfico, la autora se interesó por algo similar a los TNC: las representaciones sociales de personas que 
vivieron la última dictadura militar sin pertenecer a las fuerzas armadas ni a las organizaciones de la izquierda revolucionaria y sostienen no haber vivido el periodo militar de manera traumática ni con miedo en cuanto "no estaban metidos en nada", señalando constantemente las diferencias que encuentra entre su experiencia personal y la de los obreros que sí estaban "metidos" en política, quienes "fueron llevados por los militares"; como podemos notar, las caracterizaciones de la vida cotidiana están muy enfocadas en la vida laboral dentro de la fábrica. Las semejanzas que hallamos en este trabajo con respecto al nuestro se encuentran en las argumentaciones de las personas entrevistadas, en cuanto vemos repetirse muchas de las frases que justifican el accionar militar por ejemplo: como respuesta a la violencia que primero desataron las organizaciones de izquierda, se presenta la noción de "sociedad inocente" y se culpa a las personas desaparecidas o muertas en manos del Estado, en cuanto "en algo" estaban metidas. Pero la gran diferencia de nuestro trabajo es que no piden el establecimiento de un nuevo gobierno militar.

En un trabajo conjunto de Gómez, M., Marín L. y Yuli, M. (2007) se realizó un estudio acerca de imaginarios sociales actuales acerca de la última dictadura militar en un contexto local: la provincia de San Luis. En él se toman muchas de nuestras técnicas de investigación e incluso toma como sujetos de estudio a hombres y mujeres que vivieron el gobierno militar durante su juventud, sin haber sido víctimas directas del terrorismo de Estado. Sin embargo, su análisis no se enfoca en quienes expresan TNC, sino más bien en las secuelas que dejó el pasado dictatorial en los imaginarios sociales de las personas entrevistadas, los cuales, sin embargo, son reconocidos críticamente por los propios sujetos. Las/os autores utilizaron el concepto foucaultiano de "dispositivo" y, con él, realizaron una interpretación acerca de cómo operaba el proceso militar en el imaginario de este grupo, sobre la base de los mecanismos y estrategias de control, en palabras de ella: "El imaginario social instituido por la dictadura, si bien es evocado críticamente por nuestros informantes, dejó huellas que los sujetos experimentan como difíciles de borrar. La desconfianza, el individualismo, la falta de participación política, la cultura del "no te metas", cierto temor indefinido, pasividad frente a la autoridad, confluyen en la subjetividad de estas personas, para conformar un obstáculo en la configuración en ellos, de ese nuevo sujeto histórico cuya participación necesita el país (Gómez, M., Marín L. y Yuli, M., 2007).”

Federico Lorenz (2007), ha estudiado las memorias de quienes reivindican la última dictadura militar argentina, a las cuales denomina como memorias subterráneas que justifican la represión 
ilegal llevada a cabo por los militares, presentando como "justificación” los ataques violentos perpetrados por las organizaciones de la izquierda revolucionaria. Estas memorias son denominadas por el autor como "vulgata procesista" y explica cuáles son las argumentaciones y los relatos que la derecha presenta como "versión verdadera de la historia". Si bien esta descripción acerca de la "vulgata procesista" es análoga a los TNC, objeto de estudio de nuestra investigación, el autor se basa en los escritos de exmilitares y en argumentaciones realizadas por los medios de comunicación durante la década del setenta. Nuestro enfoque, en cambio, toma a los ciudadanos y ciudadanas que no pertenecían a las fuerzas armadas ni a ninguna institución de poder ni estatal ni privada.

Una autora que ha sido fundamental para pensar en la línea que trabajamos en esta investigación ha sido Ludmila Catela (2010). En una de sus obras versa acerca de los conflictos entre las memorias del pasado, y hace una distinción entre memorias dominantes y memorias subterráneas. Como memorias dominantes caracteriza a aquellas que denuncian al terrorismo de Estado y defienden los derechos humanos. Por otro lado, caracteriza a las memorias subterráneas como aquellas que interpelan nociones distintas a la memoria oficial, y describe un ejemplo de ello: las memorias de trabajadores que fueron víctimas de la violencia durante la dictadura en el norte argentino, específicamente en las localidades de Tumbaya y Calilegua, cuyos sistemas de clasificaciones que utilizan para narrar lo que les sucedió distan mucho de aquellas desarrolladas en las grandes ciudades del país como La Plata.

Por otro lado, Catela hace una distinción más de memorias: las memorias denegadas. Las memorias denegadas son las que más se asemejan a los TNC presentes en nuestras entrevistas, en cuanto expresan reivindicaciones claras hacia el gobierno militar; excepto que las fuentes que utiliza no son entrevistas sino información que aparece en distintos blogs de internet y revistas de derecha. Estos testimonios, en contraposición a nuestra investigación, pertenecen a familiares militares que fueron secuestrados, torturados y/o asesinados por grupos de la izquierda revolucionaria.

Testimonios No Condenatorios en coincidencia. Los TNC no existen solo en Corrientes... 
Mas allá de las diferencias que podemos hallar con respecto a otras/os escritoras/es que indagaron en temáticas similares a la nuestra, existen en esos textos testimonios de ciudadanas/os que vivieron el período militar -aunque en lugares distintos a Corrientes- cuyos imaginarios son los mismos o muy similares a los que encontramos en los TNC de nuestras entrevistas.

Hemos tomado frases representativas de imaginarios sociales presentes tanto en nuestros TNC como en trabajos escritos por diferentes autores en cuyos trabajos también se encontraron con testimonios reivindicativos o no condenatorios hacia la última dictadura militar en diferentes ciudades argentinas. Las/os autoras/es que tomaremos a modo de comparación son:

Bretal (2015), quien entrevistó a personas de la clase obrera que vivieron el período de la dictadura trabajando como operarios de la fábrica "Switt", en la ciudad de La Plata.

Carassai (2014), quien realizó entrevistas en la Ciudad de Buenos Aires, la Ciudad de San Miguel de Tucumán y el pueblo de Correa de la provincia de Santa Fe. Sus entrevistas fueron realizadas a personas de la clase media.

Garbero (2017), hizo entrevistas en la Ciudad de Córdoba, a personas de barrios aledaños a un ex centro clandestino de detención.

Levín (2005), tomó como fuente de investigación un documental realizado en 1996, en el cual se entrevistaba a vecinos y vecinas de barrios porteños donde habían funcionado centros clandestinos de detención durante la última dictadura militar.

Cabe destacar que todas las frases que se mencionarán debajo -copiadas textualmente- constituyen las expresiones más reiteradas tanto en las entrevistas realizadas en la Ciudad de Corrientes como en las otras ciudades argentinas.

\section{"Se lo merecían"}

Esta expresión hace referencia a que eran perseguidos por los militares quienes andaban en "algo raro", quienes se "lo buscaron". 
Carassai (2014) sostiene que tanto en la Ciudad de Buenos Aires, la Ciudad de San Miguel de Tucumán y el pueblo de Correa los testimonios recogidos expresan que "el que no estaba metido en nada raro, el que no tenía nada que ocultar estaba a salvo. Es decir, existía la suposición de que el Estado sabía quién estaba metido y quién no.”

Garbero (2017), en esta misma sintonía sostiene: “Algunos entrevistados sostuvieron que eran detenidas las personas involucradas en 'algo' o en 'cosas raras' o 'riesgosas'. Los entrevistados no profundizan sobre que ese 'algo' era estar 'metido' en militancia política, estudiantil o sindical'.

Bretal (2015), sostuvo que "algunas de las apreciaciones negativas tácitas (hacia los militantes de la izquierda revolucionaria) se encontraron implícitas en el señalamiento de que las víctimas estaban 'metidas en algo'. Un halo de misterio e imprecisión rodea ese 'algo'." Asimismo, se valoraba positivamente el "no estar metido en nada" de manera reiterada por parte de los trabajadores de la fábrica que fueron entrevistados.

Levín (2005), luego de analizar las entrevistas a vecinos de ex centros clandestinos de detención destaca que una de las frases escuchadas fue "alguna cosa tienen que haber hecho", lo cual demuestra "el consenso al régimen represivo".

\section{"Los excesos militares"}

Esta frase hace referencia a que los militares hicieron "lo que tenían que hacer" y que su "error" sólo fueron los "excesos" en la represión, entendido como el arresto a "personas inocentes" y el robo de bebes.

Garbero (2017), "lo condenable no es haberle dado muerte a una persona en un acto clandestino por su condición de activista político, violando las garantías constitucionales y los derechos humanos. Lo 'tremendo' se reduce a la acción contra quienes no tenían nada que ver más allá del vínculo con el involucrado (...). Lo condenable estuvo en perjuicio de los inocentes".

Bretal (2015) también hace un señalamiento de esta cuestión y expresa: "algunos ex obreros de Swift reconocieron y cuestionaron las equivocaciones de los militares al llevarse a 'gente que no 
tenía nada que ver' porque eran los 'buenos', pero no cuestionaron las detenciones de los que 'sí tenían que ver' ni sus trágicos destinos ya que eran los malos.”

Carassai (2014), observó en las entrevistas una contradicción que también estuvo presente en nuestras entrevistas: si bien las personas entrevistadas sostuvieron la idea de que los militares "sabían quienes estaban en cosas raras" la represión cayó también sobre quienes no estaban en cosas raras. Algunas de las personas entrevistadas expresaron su desacuerdo con el hecho de que los militares no les dieron la posibilidad a los detenidos de tener un juicio justo, esta característica "injusta" del gobierno de facto es señalada como otro de los "excesos de los militares". Entonces, "el deseo de que los acusados tuvieran la posibilidad de ser juzgados implica un reconocimiento de que no todos eran 'culpables'."

\section{"Sin razón"}

Con esta frase se evidencia el desconocimiento, por parte de ciertos grupos de las personas entrevistadas, de los objetivos políticos perseguidos por la izquierda revolucionaria.

Según Garbero (2017) existe en la memoria de las personas entrevistadas por ella, la idea de que los desaparecidos eran meros "asesinos". "Estas memorias cuentan de hombres y mujeres estudiantes o trabajadores vinculados a la actividad política armada. Y lo militar aparece por encima de lo político; es más, lo político está desdibujado y prácticamente ausente en los relatos sea por desconocimiento o por estigmatización."

Bretal (2015) escribió: "la información brindada por estos ex obreros sobre las prácticas de los que se llevaron por estar 'metidos en algo' los presenta como 'revoltosos', 'delegados rebeldes', 'montoneros'. Pero los motivos de la rebeldía y la acción gremial y política no fueron explicitados."

Carassai (2014): "La guerrilla tiende a ser pensada como una reacción juvenil e inmadura en la que la política no desempeña un papel fundamental.” 


\section{"Por culpa de los guerrilleros"}

Con estos términos se señala a la izquierda revolucionaria como el grupo provocador de golpe de Estado de 1976.

Garbero (2017) sostiene que las personas entrevistadas recuerdan la violencia que antecedió al golpe de Estado de 1976, como la causa principal de dicho acontecimiento: "los entrevistados recordaron los meses inmediatamente anteriores a 1976, el clima social tenso, 'convulsionado', y pusieron énfasis en la actividad de los grupos militares guerrilleros”.

Bretal (2015) también escribió que los obreros que entrevistó recordaron que "los acontecimientos de violencia comenzaron con el accionar de los activistas gremiales y las organizaciones armadas. Así la represión habría sido en respuesta a esa violencia revolucionaria, señaladas como una de las principales desestabilizadoras del orden".

\section{“Acá no pasaba nada, a mí nunca me pasó nada"}

Esta frase muestra el "desentendimiento" de las personas entrevistadas con los crímenes llevados a cabo por el gobierno militar.

Bretal (2015) nos dirá: “(los entrevistados) presentarán los hechos represivos, así como los disciplinamientos del régimen dictatorial, como externos a sus biografías personales, aún cuando los mismos hayan tenido impacto sobre ellos". Más tarde agrega: "expresaron que no percibieron un cambio disruptivo en sus vidas y en sus relatos no presentaron indicios de que les haya afectado algún disciplinamiento específico del terrorismo de Estado.

Levín (2005) analizando las entrevistas a hombres y mujeres de la Ciudad de Buenos Aires que fueron vecinos de centros clandestinos de detención. En sus entrevistas nota que "muchos de los testimonios dan cuenta de que efectivamente había indicios directos (auditivos, visuales) e 
indirectos (rumores que circulaban) en el barrio sobre la existencia de campos de concentración, pero, por otro lado, es recurrente la afirmación de que nada se sabía sobre ello.”

Una situación inversa a lo que señalaba Levín se dará en otras ciudades del interior, como Corrientes y el Pueblo de Correa del cual habla Carassai con base en sus entrevistas. En estos últimos casos se repetirán expresiones como: "acá no pasaba nada, yo nunca vi nada". ${ }^{3}$ En palabras de Carassai (2014): "En un pueblo como Correa, estos enfrentamientos (entre organizaciones de izquierda y militares), además de ajenos, resultaban lejanos; no pasaban de ser episodios que sucedían en las grandes ciudades, noticias en los periódicos (...).”

\section{"La cultura del trabajo"}

\section{Con esta expresión se separa a "la gente decente" de "los guerrilleros"}

Bretal (2015), al igual que en nuestro trabajo de investigación, observa que la carga negativa que cae sobre los militantes de las organizaciones de la izquierda revolucionaria hace referencia a que no poseían una 'cultura del trabajo', veámoslo en sus palabras: "algunos ex obreros mostraron como opuestos los valores de la cultura del trabajo con las de activismo político y/o gremial. Ellos justificaron su postura de 'no estar metidos en nada' a partir de valores propios de la cultura del trabajo como el esfuerzo y la dedicación en las actividades laborales diarias, o la importancia de mantener a la familia con el dinero producto de estas".

Garbero (2017), nos explica, a través de las entrevistas que realizó, cómo se edifica la figura de quienes formaron parte de las organizaciones de la izquierda revolucionaria, la cual se identifica con lo que la autora denominó: "el 'antihéroe guerrillero', para hacer referencia a ciertas acciones y características personales en torno a la figura del desaparecido (...). Las características de estos antihéroes son la irresponsabilidad, la imprudencia, destrucción e incluso el rótulo de asesinos. La actividad armada o relacionada con el "caos" social son las que eclipsan las razones de las luchas.

\footnotetext{
${ }^{3}$ Cabe destacar que, si bien nuestro estudio versa sobre una ciudad, la Ciudad de Corrientes, el Regimiento 9 de infantería, el cual es considerado uno de los tres Centros Clandestinos de Detención de dicha ciudad capital, se haya en la Costanera de la ciudad, sin contar con hogares de familia cercanos.
} 
Carassai (2014), con base en sus entrevistas, observa que para algunas personas la militancia política era mal vista. El "no te metas" era una posición reivindicada que aislaba al entrevistado de los sectores en pugna, reafirmaba su condición de ciudadano que cumplía con la ley y con el trabajo y que lo liberaba de situaciones "extrañas". Según algunos de sus entrevistados la militancia universitaria era asociada, cuando no reducida, a los "tirabombas" que, además, "no iban a la facultad a estudiar sino a crear problemas."

\section{"Fue necesario"}

\section{Expresión que justifica el golpe militar de 1976 y el posterior gobierno de facto}

Garbero (2017) explica que "no todos evaluaron como negativo el fuerte control y la represión ejecutada (por los militares), porque consideraron que ese maltrato era con los 'delincuentes' y por lo tanto contribuía a mantener a éstos bajo control y a proteger el orden”

Bretal (2015), comenta que "varias generalizaciones realizadas por los obreros a partir de categorías como 'montoneros', 'revoltosos', 'delegados rebeldes' fueron acompañadas de valorizaciones negativas que remiten a actitudes dañinas y a su potencial de peligrosidad, reproduciendo las valorizaciones impuestas por el régimen dictatorial que justificó su accionar represivo".

Carassai (2014), nos cuenta: “En Tucumán, el juicio desaprobatorio respecto de la brutalidad y la crueldad militares convive, en muchos testimonios, con el juicio de que esa acción era necesaria (...). El golpe de Estado de 1976, que muchos entrevistados recuerdan como algo no solamente anunciado, sino también, en cierto sentido, deseado, tiende a aparecer en los testimonios como algo que 'la gente', 'la sociedad' o ‘todos' pedían o aceptaban,"

\section{"La tranquilidad"}

\section{Expresión utilizada para calificar al período dictatorial}


Garbero (2017) dirá que "los vecinos recuerdan que durante 'el tiempo de los militares' el barrio era más seguro (...). Aun cuando los militares podían matar sin dar explicación alguna, no parecían representar un peligro". Asimismo, agrega: "son muy frecuentes las memorias que refieren al ‘tiempo de los militares' como como más seguro en tanto que no había delincuentes ni robos”.

Bretal (2015), comenta en su trabajo que los obreros expresaron haberse sentido "tranquilos" durante los años de la dictadura. Esta tranquilidad se debía a que "la persona que andaba bien a veces andaba mucho más segura de lo que podía andar en otro momento (...). Por lo tanto, este grupo de ex obreros aludió a una represión selectiva que los excluía de cualquier peligro, e incluso, los resguardaba". 


\title{
Capítulo IV
}

\section{Testimonios No Condenatorios hacia el gobierno militar, análisis de entrevistas}

\author{
"Más que un depósito de datos, la memoria es un \\ constante trabajo de búsqueda de sentido, que filtra los \\ rastros de la experiencia entregando al olvido lo que no \\ tiene más sentido en la actualidad".
}

Alessandro Portelli (2016)

Existen memorias divididas y hasta enfrentadas con respecto al período de la última dictadura militar de la Argentina. Luego de las entrevistas realizadas entre los años 2012 y 2015 a correntinas y correntinos, que vivieron el último gobierno militar en la Ciudad de Corrientes cuando eran jóvenes que concurrían a la escuela secundaria y a la universidad, podemos definir a sus Testimonios No Condenatorios hacia dicho período como discursos que resultan de vivencias, experiencias y representaciones que componen estas memorias colectivas y definen a la dictadura como un período favorable en sus vidas. Utilizamos la expresión "memorias colectivas" porque nuestro trabajo significó rastrear las representaciones sociales que se reiteraban en los diferentes discursos, pudiendo distinguir coincidencias y diferenciar dimensiones. Estas coincidencias en los discursos trascienden clases sociales, puesto que las entrevistas fueron realizadas a hombres y mujeres de diferentes ocupaciones y diferentes grados de instrucción formal.

Las representaciones sociales que iremos narrando son el eje de nuestra investigación, por cuanto nuestro interés reside en lograr determinar cuáles son las líneas comunes en los testimonios y no intentar establecer cuál es la veracidad de los hechos mencionados en cada entrevista ni, mucho menos, calificar ética o moralmente a las/os entrevistadas/os. El objetivo es contrastar vivencias y testimonios diferentes, porque, aunque suene políticamente escandaloso en un marco democrático, existen testimonios reivindicativos hacia una dictadura militar e, incluso, muchas personas piden por el regreso de los militares al poder. Estas narrativas forman parte de la sociedad y no oírlas no significa que no sigan ahí y que, incluso, como ha demostrado la historia, sirvan en un futuro de 
sostén de nuevos gobiernos autoritarios. En palabras de Franco y Levín (2007): "la noción de memoria nos permite trazar un puente, una articulación entre lo íntimo y lo público”. Las experiencias del pasado pueden usarse para muchas decisiones políticas del presente/futuro, porque al pasado se lo puede aceptar, negar, silenciar, reivindicar, olvidar o repetir. Ante este abanico de posibilidades, escogemos indagar en los testimonios no condenatorios hacia la última dictadura militar en Argentina, indagar en frases que orbitan alrededor de una que colocamos en el centro de nuestra investigación: "yo quiero que vuelvan los militares".

Indagar en los testimonios no condenatorios hacia la última dictadura militar nos lleva a la obligación de especificar sobre la temporalidad histórica que asumimos. Cabe destacar que trabajar con TNC es trabajar con memorias, significa indagar en testimonios que desde el presente hablan del pasado, no se trata de historizar qué pasó en la década del setenta mediante entrevistas del presente, porque, tal como lo señala Portelli, el estudio de la historia reciente "no pretende conocer los hechos históricos a partir de la memoria de los individuos como si estos fueran repositorios pasivos de datos coherentes y asequibles, sino acceder mediante sus testimonios a las subjetividades" (Portelli, 1991).

Luego del trabajo de campo, el cual consiste en 96 entrevistas realizadas a correntinas y correntinos, de diferentes clases sociales, que vivieron el período militar en la Capital de Corrientes, pudimos distinguir una división en los discursos:

1- Testimonios No Condenatorios de "reivindicación explícita", discursos que avalan el accionar de las fuerzas armadas y policiales y piden el regreso de los militares al poder.

2- Testimonios No Condenatorios de "reivindicación implícita": discursos que avalan el accionar de las fuerzas armadas y de seguridad y/o aspectos del gobierno militar, pero dicen preferir el régimen democrático.

3- Testimonios Condenatorios: discursos que no resaltan ningún aspecto positivo del régimen militar y condenan el período de manera tajante.

Cabe destacar que en el presente trabajo de investigación únicamente nos enfocaremos en los imaginarios sociales presentes en los Testimonios No Condenatorios de "reivindicación explícita" y en los Testimonios No Condenatorios de "reivindicación implícita". 
Observemos fragmentos de testimonios en los cuales se menciona claramente el deseo de un nuevo gobierno militar:

“¡La época de los militares, qué hermosa época!, jescribi eso: "qué hermosa época, fue la mejor de mi vida”, yo quiero que vuelvan los militares! Yo hablaba con un amigo, ayer justamente, y me decía que la mejor época de su vida también fue durante el gobierno militar (...). En esa época no había terror hacia los militares, el que sentía miedo era por algo. Se hablaba de política, llevábamos una vida normal, salíamos a bailar y nunca me pasó nada. Podías dejar tu casa abierta y no pasaba nada. Hoy hay una inseguridad total. La inseguridad es el defecto de la democracia. El gobierno les hace un lavado de cabeza a los jóvenes con respecto a los militares para que estos no vuelvan más." (Entrevista Anónima, 20 de noviembre de 2012, Corrientes Capital).

"Yo quiero de nuevo un gobierno militar. Porque a mí la democracia no me cambió nada, al contrario, me quitó cosas, ahora no se puede ni salir a hacer mandados porque te matan”. (Entrevista a Laura Céspedes. 23 de diciembre de 2014, Corrientes Capital).

"Desearía un gobierno militar ahora, aunque mas no sea por un tiempo, porque nos invadieron los delincuentes, no podemos mandar solos a nuestros hijos a la calle, los negocios viven con rejas y sus dueños con miedo, los jóvenes no estudian ni trabajan solo se drogan, hace falta un gobierno militar fuerte que venga a poner orden, ellos saben cómo manejar estas cosas.” (Entrevista Anónima, 27 de enero de 2015, Corrientes Capital).

A continuación, mencionaré ejemplos de los testimonios denominados, en esta investigación, “de "reivindicación implícita"”:

“Los militares hicieron algunas cosas bien, mantenían el orden, la tranquilidad y la seguridad de todos quienes apoyábamos mantener los valores de nuestros padres. Mientras siga respetándose el orden democrático y nuestros politicos demuestren capacidad de gestión aceptando y respetando la división de poderes no justificaría la intervención de los militares en el poder." (Entrevista Anónima, 24 de julio de 2013, Corrientes Capital). 
"Sólo optaría por un gobierno militar otra vez en caso de que no sepamos convivir en democracia, especialmente considerando que muchas personas no han entendido que es vivir en democracia." (Entrevista Anónima, 20 de septiembre de 2012, Corrientes Capital).

"En la época de los militares los que no teníamos nada que ver con las guerrillas transitábamos libremente, sin que nos molesten. Yo no tengo nada en contra de la democracia, pero me gustaría que regresen los militares si continua esta inseguridad, porque uno no anda tranquilo transitando por tantos asaltos que hay actualmente." (Entrevista Anónima, 28 de agosto de 2012, Corrientes Capital).

Considerando que la cultura no cambia de modo repentino, confiamos en la factibilidad de pensar las memorias colectivas como universos que contienen imaginarios afectivos, cognitivos y valorativos. Imaginarios que versan acerca de actitudes y creencias con respecto al sistema político y al rol de ciudadano, entre otras cuestiones. En otros términos, proponemos un análisis que parta de la perspectiva del actor, lo que Guber (2013) expresa como: "ese universo de referencia compartido (...) que subyace y articula el conjunto de prácticas, nociones y sentidos organizados por los sujetos."

Los Testimonios No Condenatorios y las conexiones entre el pasado y el presente

"El pasado es un terreno de disputas políticas alimentadas por el presente" Federico Lorenz

"La memoria es también algo que sirve para molestarnos, para poner en duda las certezas y las creencias que nos tranquilizan" Alessandro Portelli

A continuación, trascribiremos algunas las frases concretas, ejemplos cabales de Testimonios No Condenatorios de "reivindicación explícita" hacia el gobierno militar de 1976-83, que fueron 
utilizadas por los informantes a la hora de expresar su preferencia de un gobierno militar a uno democrático y el porqué de dicha preferencia:

I. "En ese tiempo..., iqué hermosa época! Escribi eso: "QUÉ HERMOSA ÉPOCA”, yo quiero que vuelva esa época, ese gobierno (...). Yo no podría decir nada malo de la dictadura, yo disfruté de mi juventud y no tuve problemas porque no anduve en nada raro, el que tuvo problemas con los militares por algo habrá sido. Desde mi punto de vista fue necesario un gobierno de facto, un gobierno como el de hoy no podría con el desastre que había en el país; ahora estamos volviendo a eso (...). No conozco a nadie de mi edad que se queje de esa época, hablan mal de ella sólo los jóvenes que no la vivieron." (Entrevista a Mario Gómez, 26 de enero 2015, Corrientes Capital).

II. “ 'Ojalá vuelva todo eso ahora, para que no haya la droga ni robos. Yo prefiero los militares y no que vayan a drogarse y que te maten por dos pesos. Mis hijas se iban a bailar y volvían a las cuatro de la mañana y nadie las molestaba, ahora no podés salir, hay que tomar taxi o remis hasta la puerta de tu casa y en la misma puerta de tu casa te entran. Ahora, yo quisiera que vuelvan los militares.” (Entrevista Anónima, 27 de diciembre de 2015, Corrientes Capital).

III. "Yo deseo el regreso de los militares, aunque mas no sea por un tiempo, porque nos invadieron los delincuentes, ya no podemos mandar solos a nuestros hijos a la calle, los negocios viven con rejas y sus dueños con miedo, los jóvenes que no trabajan ni estudian, solo se drogan y emborrachan, roban, todo está mal.” (Anónimo, entrevista, Corrientes Capital, 11 de julio del 2015)

IV. "Yo optaría por un gobierno militar otra vez para que vuelva el control y el orden a la sociedad, control a la delincuencia, como las drogas que están al alcance de la sociedad más vulnerable, como sucede hoy en la 'democracia' (hizo comillas con sus dedos)." (Entrevista Anónima, 23 de enero del 2015, Corrientes Capital).

V. $\quad$ "Me gustaría que vuelvan los militares, porque existe mucha inseguridad en las calles y nuestros gobernantes no invierten en protegernos y además existe mucho descontrol y corrupción en quienes nos gobiernan y se aprovechan de los que realmente salimos a 
trabajar todos los días del año para cobrar un pequeño salario.” (Entrevista Anónima, 15 de julio del 2015, Corrientes Capital).

VI. "La verdad es que quiero que vuelvan los militares, debido a que nuestro país se llenó de chorros y matones y así sacar a la delincuencia de la calle." (Entrevista Anónima, 18 de julio del 2014, Corrientes Capital).

VII. "Yo prefiero un gobierno militar, para vivir tranquilo, dentro del orden y la seguridad, sin patotas en las esquinas, en las plazas..." (Entrevista Anónima, 20 de enero del 2015, Corrientes Capital).

VIII. "Yo quiero nuevamente un gobierno militar, porque así no habría tanta droga, vandalismo, tanta inseguridad en todas partes. Además, me gustaría que vuelva el servicio militar para que la juventud busque una formación”. (Entrevista Anónima, 24 de septiembre de 2013, Corrientes Capital).

IX. "Prefiero mil veces aquella época de respeto, seguridad, normas de conducta a este libertinaje que se llama "democracia" (el entrevistado puso cara de asco al decir “democracia” y utilizó sus dedos para hacer comillas en el aire).” (Entrevista Anónima, 5 de junio de 2012, Corrientes Capital).

X. $\quad$ "Me gustaría que regresen los militares si continúa aumentando la inseguridad, porque uno no anda transitando seguro por tanto asalto que hay actualmente. En la época de los militares los que no tenían nada que ver con la guerrilla se trasladaba libremente, sin que lo moleste, no había inseguridad.” (Entrevista Anónima, 28 de agosto de 2012, Corrientes Capital).

Franco y Jelín (2007) sostienen que "La historia reciente se enfoca en el pasado cercano, en actores vivos del pasado, en las diversas formas de coetaneidad entre pasado y presente" No obstante, los testimonios cambian si entrevistamos a una persona en 1976 y luego en el 2012. Por este motivo, los estudios de memoria social no se proponen historizar ni fechar hechos y acontecimientos tal cual hayan ocurrido, contrariamente se enfoca en estudiar los discursos, los imaginarios sociales, las maneras colectivas de recordar. En otros términos: la memoria realiza conexiones entre el 
pasado, el presente y el futuro. Conexiones, que, si dirigimos hacia el espectro político, nos puede brindar información, entre otros aspectos, acerca del ideal de gobierno y del ideal de ciudadana/o.

Para ejemplificar estas conexiones entre el pasado y el presente, tomaremos tres dimensiones de análisis, en el marco de cada una de ellas se indagará en los imaginarios sociales que las conforman:

La primera dimensión de análisis hace referencia a los "saberes" referidos a las causas por las cuales las/os entrevistadas/os consideran que sucedió el golpe militar de 1976 y los hechos más sobresalientes que recuerdan del período. Esta dimensión se relaciona con el tipo de información que se posee sobre el período militar-académica, reflexiva, irreflexiva, inexistente, confusa, extensa, limitada, etc.

> La segunda dimensión de análisis se relaciona con los "valores" relacionados con la política. Es decir: los ideales de gobierno y de ciudadana/o. Esta dimensión alude a las ideologías (formación doctrinal), percepciones, valores, concepciones e información que poseen acerca del gobierno y su rol, de las jerarquías. También hace referencia a las actitudes políticas, tales como las posturas y las disposiciones -provocativa, reflexiva, pasiva, indiferente, comprometida, etc. Asimismo, se pregunta por aquellas nociones, valorizaciones y opiniones que poseen acerca del rol que debe cumplir un ciudadano, qué es valorado como adecuado/inadecuado, fructífero/intrascendente, normal/anormal, coherente/incoherente, entre otras cuestiones.

- La tercera dimensión se abocará a indagar en las "emociones" relacionadas con el período militar, las cuales, a modo de ejemplo, pueden variar entre miedo, culpa, aceptación, indiferencia, malestar, enojo, etc. Para explorar las emociones se torna necesario preguntar por las experiencias personales durante el gobierno militar. Esta dimensión indaga en las experiencias vividas durante el periodo militar y las modificaciones y/o continuidades en su vida cotidiana.

Narrativas de lo sucedido: conocimientos sobre las causas de la toma del poder por parte de los militares en 1976 y explicaciones acerca de qué sucedía en el país 
Este apartado se propuso describir los imaginarios sociales que poseen las/os entrevistadas/os acerca de los acontecimientos sucedidos antes y durante el período 1976-83. Acontecimientos tales como las causas que se recuerdan acerca de la toma del poder por parte de las fuerzas armadas y las narrativas acerca de lo sucedido en el país durante el período militar.

En los testimonios, los imaginarios compartidos acerca de las causas del golpe de Estado de 1976, resaltan la implicancia de la expresidenta Isabel Perón, de López Rega y los "subversivos". A Isabel la califican como inoperante en medio de un caos general, caos generado por "terroristas" y caracterizado por asesinatos constantes por parte de subversivos "anti-argentinos" que querían "tomar el país". Este clima provocará que sean civiles quienes "toquen las puertas de los cuarteles" para "solucionar el problema de las guerrillas", según las/os entrevistadas/os. Los militares se vieron "obligados" a tomar el poder, porque "eran los únicos" que podían brindar una solución para el cual la democracia era impotente. El $78 \%$ de la totalidad de los entrevistados y entrevistadas sostuvieron estas ideas, dentro de este porcentaje están incluidos universitarios y no universitarios, personas que expresaron Testimonios No Condenatorios y personas con Testimonios Condenatorios hacia la última dictadura. Veamos ejemplos tomados de las entrevistas:

"La toma del poder por parte de los militares fue una acción en respuesta a la guerrilla armada que secuestró y asesinó a empresarios, sindicalistas, militares y también personas que circunstancialmente estaban en los lugares donde ponian bombas". (Entrevista Anónima, 13 de enero del 2014, Corrientes).

"Los estudiantes querían que vuelva Perón, mientras Perón coqueteaba con la derecha y la izquierda. La izquierda eran los estudiantes. Los estudiantes comenzaron a matar soldados, de eso no se habla. Los militares reaccionaron haciendo desastre también. Lo que no nos dábamos cuenta es que Perón hablaba con ambos sectores, hasta que llama a los izquierdistas imberbes en un acto y se separa de ellos definitivamente. Todo se veía por televisión”. (Entrevista a Aurora Pino, 20 julio del 2014, Corrientes Capital).

"Esta dictadura se desarrolló a mi entender porque el gobierno democrático de Isabel Perón fue dominado por López Rega y otros, donde predominaba la Triple A, los montoneros, el ejército revolucionario del pueblo y se desmembró todo con asesinatos y 
robos de armas, los militantes montoneros y otros querían entrar al país con sus regímenes”. (Entrevista Anónima, 20 de julio del 2014, Corrientes Capital).

"La causa de la dictadura fue el pésimo gobierno de Isabelita Perón y por el gran avance de la lucha armada de los grupos de la izquierda armada”. (Entrevista Anónima, 3 de julio del 2014, Corrientes Capital).

"Los militares tomaron el poder por las luchas facciosas, la muerte presente cotidianamente, la acción de la guerrilla y el terror sembrado por la Triple Alianza, los secuestros a civiles por parte de grupos terroristas". (Entrevista Anónima, 29 de septiembre del 2014, Corrientes Capital).

“Los militares llegaron por pedido generalizado de la población ante la falta de idoneidad de los políticos gobernantes y además la misma presidenta ordenó la intervención de los militares”. (Entrevista Anónima, 16 de diciembre del 2015, Corrientes Capital).

"El golpe de Estado se produjo a raíz de que en ese momento nuestro país vivía un ataque terrorista y los militares tomaron el mando del gobierno con el propósito de restaurar la paz”. (Entrevista Anónima, 23 de febrero del 2015, Corrientes Capital).

Como podemos observar, es muy recurrente en las entrevistas señalar al gobierno "pésimo" de Isabel Perón y a la Triple "A”, como antecedentes del golpe de Estado de 1976. Al respecto, Franco (2012) nos dirá: las acciones de las organizaciones armadas de izquierda fueron presentada por el peronismo del período 1973-76, como un problema de carácter policial, los grupos revolucionarios fueron definidos como "delincuentes".

Otro porcentaje menor de entrevistadas/os sostuvo como principales causas del golpe de estado de 1976: “intereses económicos de los grandes sectores del poder nacional y extranjero", "interés de EEUU", quien nos impuso un modelo de país que les beneficiaba a ellos, interés de la derecha de abortar los planes de país de la izquierda" y "el oportunismo por parte de civiles poderosos y militares, quienes aprovecharon la situación de violencia que atravesaba el país, para hacerse con el poder”. Este grupo de testimonios con imaginarios diferentes, está conformado, casi en su totalidad, por universitarios. Veamos un ejemplo de las entrevistas: 
"En aquellas épocas las democracias de América Latina eran débiles, posibilitando la intromisión de ideas marxistas para ocupar territorios y ante semejante amenaza las potencias del Norte influían sobre militares para tomar el poder de la Nación y evitar así que se repita lo de Cuba en otros países". (Entrevista Anónima, 27 de enero del 2015, Corrientes Capital).

En cuento a los culpables del golpe de estado, los entrevistados y entrevistadas señalaron que fueron los "guerrilleros", quienes comenzaron a "poner bombas" y "matar gente", a lo cual desde el gobierno peronista se respondió creando la "Triple A", generando esta situación un clima de caos por el cual "debieron" asumir los militares al poder. Las/os entrevistadas/os señalaron como el momento de inicio del caos y la violencia, el aterrizaje de Juan Domingo Perón en Ezeiza, momento en el cual se sucedieron tiroteos y él mismo echó a un sector de militantes llamándolos "imberbes", quienes, según sus palabras, luego serían los "Montoneros". No obstante, solo se recuerda como "caótico" al gobierno de Isabel, mientras que "con Perón estaba todo bien".

Se sucede un quiebre entre las/os entrevistadas/os a la hora de explicar cuáles eran los objetivos de los Montoneros y de diferenciarlos del ERP. Usualmente los relatos de personas con títulos universitarios logran describir las ideologías de izquierda, mientras que los no universitarios dicen desconocer absolutamente los objetivos de éstos, alegando solamente que poseían "ideologías extranjeras" que querían imponer a la Argentina y que no tenían "nada que ver" con la idiosincrasia del país.

Con respecto a los jóvenes que los militares buscaban y "se llevaban", los entrevistados y entrevistadas señalaban que eran universitarios adinerados, puesto que "el pobre no tiene tiempo para la política y su cotidianidad reside en trabajar y estar con los hijos", destacando que las pensiones eran habitadas por jóvenes del interior de la provincia, perteneciendo a los movimientos de izquierda solamente "los hijos de", es decir, jóvenes correntinos de las familias tradicionales de la provincia y porteños que venían a Corrientes "de paso, a descansar" o a "esconderse" del gobierno. Una de las primeras diferencias en los relatos surge cuando los entrevistados universitarios dijeron haberse sentido más vulnerables por el hecho de que en aquel tiempo "se sabía" que los militares te podían "llevar" sólo por ser conocido, amigo, amigo de un amigo de un 
"subversivo" o "confundirte" con uno. Sin embargo, tanto los universitarios como los no universitarios sostuvieron que "no sentían miedo, porque no andaban en nada raro" y que la policía y los militares "sabían a quienes buscaban" y que "no se metían" con "los ciudadanos comunes".

Otro hecho que recordaron las/os entrevistadas/os como el "inicio de Montoneros" fue el secuestro y asesinato de Aramburu, lo cual señalan como el mismo inicio de los militares a "hacer lo que tenían y sabían hacer".

Tanto en los imaginarios sociales de los entrevistados y entrevistadas cuyas expresiones manifestaron TNC de "reivindicación explícita" como así también TNC de "reivindicación implícita" -grupos en los cuales convergen tanto personas sin títulos universitarios, como universitarios y docentes- la definición de las causas de la toma del poder por parte de los militares fue la "incapacidad del gobierno de Isabel Perón" para evitar detener a las agrupaciones políticas de la izquierda revolucionaria, la cual es mencionada en las entrevistas con los siguientes términos: “guerrilla", "subversivos", “extremistas", "terroristas", “delincuentes", “montoneros" y "ERP”. La izquierda revolucionaria, para nuestras personas entrevistadas, constituye el único "demonio", el cual fue necesario y legítimo eliminar, porque "eran asesinos desquiciados" y "querían imponer ideologías extranjeras", iniciando ellos la violencia que luego culminaría con el golpe militar de 1976. Si tomamos en cuenta este punto de vista, la de un demonio, podemos visualizar ese universo de significados sobre los cuales se elaboran los Testimonios No Condenatorios. La violencia llevada a cabo por el gobierno militar no es entendida de manera negativa, sino más bien legítima. Veamos lo que señalaba un entrevistado:

"Está bien que las Abuelas de Plaza de Mayo reclamen por sus nietos desaparecidos, pero nadie se pregunta qué hacían ellas en esa época o sus hijos." (Entrevista a Mario Gómez, 26 de enero 2015, Corrientes Capital).

La teoría de los dos demonios aparece en los relatos, sobre todo en dos de las explicaciones que dan las/os entrevistadas/os acerca del gobierno militar. La primera en cuanto la capacidad de violencia que podían ejercer las organizaciones de la izquierda revolucionaria y la del Estado son equiparadas, puesto que los entrevistados y entrevistadas no lo juzgan, ni siquiera lo mencionan; en concordancia a ello reclaman que los "subversivos" sean juzgados de la misma forma en que fueron juzgados los militares. La segunda narrativa se relaciona con el rol que el cual se auto- 
perciben: "la gente común no tenía nada que ver", "nosotros no sabíamos nada, nos enteramos de todo después", "nosotros veíamos todo desde afuera, como si fuera una película". No obstante, la "teoría de los dos demonios" pareciera no ser suficiente para explicar los TNC de las correntinas y correntinos entrevistados en este trabajo de investigación, con respecto a un aspecto: los militares no son demonizados, únicamente lo son los "subversivos", "terroristas", "guerrilleros". Para ejemplificar esta afirmación veamos un testimonio:

"La gente común, de aquella época, prefería a un militar antes que a un guerrillero. 'Montonero' era una mala palabra. Veías a un soldado y te sentías protegida. Hoy no sentís ningún respeto por los policías ni te sentías protegida. La delincuencia no existía, comenzó con la democracia. Hoy vivimos un caos. Con la democracia se perdieron valores fundamentales como el respeto y la cultura del trabajo." (Entrevista a Sonia Gutiérrez, 15 de diciembre de 2014, Corrientes Capital).

“La mayoría de los jóvenes solo sabe la versión de este gobierno. Está bien que haya ido preso el militar que mató, pero yo quiero ver que ahora se les hagan juicios a los montoneros. Pero es tanto el odio de esta gente que sigue creando división social". (Entrevista a Laura Céspedes, 23 de diciembre de 2014, Corrientes Capital).

“Yo me iba y venía de la facultad y nunca me pasó nada (...). Lo que siempre sucedía era que te pedian el DNI por la vía pública. En Corrientes no pasaba nada, para nosotros la subversión pasó desapercibida”. (Entrevista a Domingo Quiroz, 22 agosto de 2013, Corrientes Capital).

Asimismo, se observa una desconfianza acerca de que existieran personas desaparecidas y/o torturadas en el período, veamos un testimonio:

“(...) Según lo visto y escuchado, desaparecieron personas, yo no sé, a mí no me consta, yo nunca vi nada raro, te digo: fue un periodo normal, se vivía bien”. (Testimonio Anónimo, 5 de enero del 2012, Corrientes Capital).

“(...) Si tuviera que elegir elegiría un gobierno militar, pero sin las cosas que escuché que hicieron y digo "es-cu-ché", porque yo nunca vi nada”. (Entrevista a Sonia Gutiérrez, 15 de diciembre de 2014, Corrientes Capital). 
Entre los relatos de los TNC de "reivindicación explícita" un porcentaje señaló que "no podría decir nada malo del gobierno militar", pero el resto de entrevistadas/os que sí señaló "lo malo" del período, expresaron las siguientes características: el robo de bebés, no haber juzgado mediante tribunales, la falta de libertades para expresarse, la muerte de inocentes y los "excesos" en la represión. Sin embargo, luego de estos señalamientos expresaron firmemente: "yo deseo que vuelvan los militares". Podemos observar que nuevamente se relaciona "los aspectos negativos" del gobierno militar con "algo que les pasó a otras personas", que no se puede defender pero que, al mismo tiempo, se "lo buscaron". Veamos algunos casos:

“(...) Creo que fueron negativos los excesos en la manipulación de los órganos de gobierno y el control sobre ellos, para poder hacer lo que se les antojaba, iojo!, como lo es ahora en 'democracia' (comillas del entrevistado). La falta de participación de la sociedad y de grupos politicos, la libertad de prensa y de expresión, como también pasa ahora. Pero eran reprimidos los que no respondian al orden militar (...). Yo estaría conforme si vuelven los militares, pero me gustaría que sea un gobierno cívico-militar (...)." (Entrevista anónima, 12 de enero de 2015, Corrientes Capital).

“(...) considero que fue mala la represión que tuvieron que hacer los militares, desaparecieron mucha gente y a veces inocentes como ser menores de edad, los hijos de los guerrilleros. Algo negativo también era que no se podia expresar libremente algún pensamiento o ideología contraria a sus principios. Fueron perseguidos los guerrilleros y todos aquellos que representaban a algún grupo político que militaba en contra del gobierno (...). Me gustaría que vuelvan, porque existe mucha inseguridad en las calles (...)” (Entrevista Anónima, 27 de diciembre 2015, Corrientes Capital.)

Estos testimonios describen aun lo que señalábamos con anterioridad: la violencia llevada a cabo por los militares en contra de las organizaciones armadas de la izquierda revolucionaria no es considerada un aspecto negativo. Particularmente, lo que sí es criticado a los militares en los TNC, en casi la mitad de las entrevistas, es la apropiación ilegal de bebés. Mencionaremos algunos ejemplos de las entrevistas:

"Para mí lo que hicieron los militares con respecto a la guerrilla, esos que mataban y secuestraban, estuvo bien, pero se pasaron e hicieron lo que no tendrían 
que haber hecho. La guerra contra la guerrilla estaba bien, porque eso habia que frenar, pero después no sé qué pasó con eso de los desaparecidos, eso para mí fue horrible, el robo de bebes (...), para mí eso es una cosa horrible (...), eso fue el gran defecto, en lo que se pasaron. Pero con lo de la guerrilla estoy totalmente de acuerdo". (Entrevista a Ricardo Romero, 2 de marzo de 2015, Corrientes Capital). "El gobierno militar encontró una solución a los problemas de ese momento que eran principalmente el del terrorismo (...). La parte negativa del gobierno militar fue la muerte de gente inocente que nada tenía que ver con los terroristas y la entrega de bebes recién nacidos a otras personas y no a sus propios familiares. (...) para mi es mejor la democracia porque nos permite elegir a nuestros gobernantes (...)”. (Entrevista Anónima, 16 de julio de 2015, Corrientes Capital).

Por otro lado, se legitima la muerte de los "terroristas, guerrilleros, subversivos", cuando se señala que "el error de los militares" fueron "los excesos", "haber matado inocentes; es decir, a personas que no eran "culpables". Nuevamente se legitima el asesinato de quienes fueron señalados, en aquel tiempo, como "enemigos", sólo se critica "la manera excesiva" en la cual fue llevado a cabo. Veamos algunos de los TNC de "reivindicación implícita", los cuales, si bien no expresan de manera directa desear un nuevo gobierno militar, comparten muchos de los imaginarios sociales de los TNC de "reivindicación explícita":

"Ellos asumieron para reprimir la acción guerrillera que llevaban a cabo un grupo de personas que generaron desorden y riesgo civil (...). Los militares solo perseguian a los subversivos y quizás en exceso a algunas personas que no tenían nada que ver (...). Yo prefiero la democracia, siempre y cuando sea ejercida correctamente (...)” (Entrevista Anónima, 10 de marzo del 2014, Corrientes Capital).

Las personas entrevistadas que expresaban TNC de reivindicación implícita, usualmente, cuando decían "preferir la democracia" antes que un nuevo gobierno militar, hacían una salvedad: "prefiero la democracia siempre y cuando sea bien ejercida", "siempre y cuando se respete la constitución", "siempre y cuando los gobernantes no roben", "siempre y cuando no se perpetúen en poder", etc. En otros términos, "la democracia es muy imperfecta, mejor un buen gobierno militar". Lo único que se le cuestionó al régimen militar fue el robo de bebés y no haber hecho 
juicios a las personas acusadas. Las exigencias hechas para con la democracia, como podemos apreciar, no fueron enunciadas para con el régimen militar.

La expresión de "guerra" también es común, "guerra entre dos bandos que se mataron entre sí", se habla de "guerra" porque las personas entrevistadas entendieron al período como un enfrentamiento entre "militares patriotas" y "terroristas de ideologías extranjeras que querían apoderarse de la Argentina". Al mismo tiempo la palabra "dictadura" no se menciona, se utiliza la expresión "la época de los militares". Recordemos que lo que no se nombra no existe. Veamos dos ejemplos:

"No creo que haya algo negativo, fue una guerra donde moría el que trabajaba para estas agrupaciones, no tenía problemas el que no se involucraba". (Entrevista Anónima, 20 de julio del 2014, Corrientes Capital).

"Fue una guerra entre dos bandos, por eso pienso que AMBOS fueron perseguidos, ya que había muertos, secuestrados, etc. Tanto por parte de los subversivos como de los militares". (Entrevista Anónima, 30 de mayo del 2015, Corrientes Capital).

Los "valores" relacionados con la política. Los ideales de gobierno y de ciudadana/o

Ideales de ciudadana/o

Dentro de los imaginarios que versan acerca de los valores relacionados con la política y sobre el "ideal de ciudadano", pudimos distinguir una antítesis: por un lado, se hayan quienes hemos denominado la "gente decente" y, por otro lado, las/os "ciudadanas/os indecentes". Estos imaginarios significan, por supuesto, salvar a los primeros y desprenderse y culpabilizar a los segundos. El imaginario sobre "gente decente" ha sido trasversal a los TNC de "reivindicación explícita" y a los TNC de "reivindicación implícita". Veamos el fragmento de un relato:

"Que vuelvan los militares siempre y cuando respeten los derechos de los ciudadanos decentes. Porque creo que esa sería la cura para tanta delincuencia y violencia sin sentido." (Entrevista Anónima, 10 de julio del 2015, Corrientes Capital). 
Según los imaginarios sociales presentes en los relatos que las/os propias/os entrevistadas/os sostuvieron sobre el período militar, el grupo de la "gente decente" está conformado por aquellas personas que se dedican a estudiar, sea en el nivel secundario o estudios superiores -sin cuestionar a la autoridad-, a trabajar - sin realizar huelgas ni manifestaciones- y a cuidar a la familia intentando que las/os hijas/os cumplan con esas mismas premisas-. Salirse de este esquema significaría "andar en cosas raras" y "buscarse problemas innecesarios". Es escogida la palabra “decente" porque es la que utilizan las entrevistadas y entrevistados. Quizás los subversivos son considerados "no decentes" porque escapan a esta lógica y ocupan su tiempo en combatir a la autoridad utilizando la violencia, característica que describe a un delincuente. Especialmente esta lucha por "cambiar" el "orden", tachada como inapropiada, puede ser relacionada con una característica política-cultural: el conservadurismo.

Los relatos dejan ver que involucrarse en política, siendo de una clase social no adinerada, también es considerado algo "extraño" por las/os entrevistadas/os no universitarios, quienes relatan que quienes solo deben trabajar para satisfacer necesidades básicas no tienen tiempo de hacerlo, calificando de "nenes de mamá" y de "hijos de" a los jóvenes que sí lo hacían porque "podían perder tiempo". Para las personas universitarias, las/os jóvenes que militaban en organizaciones de la izquierda política, también "perdían el tiempo", pero por otra razón: porque sus ideales eran "utópicos" e "irrealizables", una "locura suicida" de la cual "la mayoría de la población no estaba contagiada". Así hablaba un entrevistado:

"Yo sentía lástima por los revolucionarios, porque sabíamos que tarde o temprano les iba a ir mal. Además, eran grupos cerrados, no sabiamos qué hacian, pero si estaban metidos en el lío que se la banquen, corrían peligro porque querían. El pueblo no estaba contagiado de esas ideas, nada que ver, eran ideas de afuera. Los que estaban metidos en esos grupos terroristas eran adultos, sabían las consecuencias de sus actos, yo pensaba que si se los llevaban era su problema. Ellos no eran víctimas, ellos sabían lo que hacían y lo que podia pasar”. (Entrevista a Jorge Sanabria, 23 de julio de 2015, Corrientes Capital).

Pero, "no andar en cosas raras" también se relaciona, en los imaginarios sociales, con las noticias que los medios de comunicación pasaban en aquellos años; es decir con atentados, con la violencia. La lógica sería la siguiente: la gente decente llevaba una "vida normal", "se dedicaba a trabajar, 
no se metía en política-problemas" y, entonces, "los militares no le molestaban”. Al mismo tiempo, "andar en cosas raras" significaba provocar, "hacer algo" para que los militares o policías te detuvieran. Es decir, existen en los imaginarios cierto "desinterés o desentendimiento" (las comillas son mías) a la hora de pensar las consecuencias que "al otro" le esperaba. Lo curioso es que ninguna de las personas entrevistadas que expresaron TNC supieron explicar con exactitud en qué consistía "andar en algo raro"; ninguna de estas personas relacionó a las organizaciones de izquierda revolucionaria con un proyecto de país más justo, equitativo o justo, y, mucho menos, que la violencia ejercida desde el Estado servía para aniquilar ese proyecto. Es decir, el uso de la violencia por parte de las organizaciones de izquierda revolucionaria y de las fuerzas armadas tenían objetivos diferentes, proyectos de país diferentes, los cuales, evidentemente, es desconocido para quienes reivindican a la dictadura militar.

En contraste, las/os universitarias/os que fueron entrevistadas/os condenaron la dictadura militar, y aunque sí tenían ciertas nociones acerca de los objetivos políticos que perseguía la izquierda, siempre los calificaron de "irreales", "utópicos", "alejados de la idiosincrasia argentina", "destinados al fracaso", "rebeldías típicas de la juventud", etc. Se critican los "excesos de las Fuerzas Armadas", pero no se plantearon las divergencias entre los proyectos de país en pugna cuando se desató la dictadura. Veamos como ejemplo el fragmento de una entrevista:

"En Corrientes no eran bien visto los montoneros. Nos daba bronca que los subversivos mataban a militares, eso era mal visto por la gente. Toda la juventud es rebelde, los guerrilleros eran eso. Los estudiantes, al principio, simpatizaban con los montoneros, pero se pasaron de mano, mataron gente inocente y fueron mal vistos. " (Entrevista a Domingo Quiroz, 22 agosto de 2013, Corrientes Capital).

Los "ideales de ciudadano" son fundamentales para comprender los TNC hacia el gobierno militar, lo son en cuanto exponen las representaciones de qué es "lo correcto/incorrecto", "lo aceptable/no aceptable", "lo que merece ser castigado" y "rol que un ciudadano debe cumplir". Los imaginarios sociales acerca de este rol fueron resumidas en una categoría denominada por nosotros como: “el discurso de la decencia". 
"Fueron perseguidos todos los que no tenían conductas de ciudadanos respetuosos de las normas de convivencia y querían hacer justicia social por mano propia. Prefiero mil veces aquella época de respeto, seguridad, normas de conducta a este libertinaje que se llama “democracia”. (Entrevista anónima, mayo 2014, Corrientes Capital)

El discurso de la decencia, se refiere a cumplir con un rol de ciudadana/o que no cuestiona la autoridad, forma una familia, trabaja y se esfuerza, sin "meterse" en política. Pero profundicemos más la descripción de estas representaciones. Para las/os entrevistadas/os la "gente decente" era aquella que dedica la totalidad de su tiempo a cumplir con obligaciones cotidianas. Obligaciones individuales, como las de sostener económicamente y/o cuidar a la familia. Las personas decentes son aquellas con preocupaciones que no escapan al "día a día", al desarrollo personal. Son luchas "útiles" para sus hijos, nietos, padres, utilidad que únicamente se puede ejercer a través de canales tradicionales, "el laburo", ser un "verdadero" estudiante, "no andar en cosas raras". Lo "raro" es todo lo que escape a la rutina de trabajar, descansar y cuidar a la familia. Los "decentes" son los "normales". En contraposición, por ende, se encuentran los "anormales", los "loquitos", subversivos, los no decentes, los buscados por la policía por andar en cosas "raras". En otras palabras, los subversivos se alejaban de su cotidianidad y los militares volvían las cosas al "lugar sano". Veamos más testimonios:

"Los militares perseguian a los niños de papá que estaban al divino botón, que solo concurrían a la facultad a molestar y ponerles ideas raras a los chicos en la cabeza, perseguian solo a quienes se juntaban para molestar al gobierno" (Entrevista Anónima, 16 de julio de 2015, Corrientes Capital).

"La juventud normal no se metía en problemas porque estaba ocupada en trabajar o estudiar o en ambas cosas. Los universitarios de clase media y alta eran los montoneros. Ellos querían cambiar el mundo y nos querían arrastrar en esa idea". (Entrevista a Laura Céspedes, 23 de diciembre de 2014, Corrientes Capital).

“(...) El que se comportaba socialmente bien, que cumplia con su trabajo y respetaba las leyes vivía tranquilamente. Eran perseguidos los que andaban por izquierda, en cosas raras" (Entrevista Anónima, 25 de febrero de 2014 Corrientes Capital). 
La reivindicación hacia el accionar violento de los militares se pueden visualizar en todos los discursos, tanto de universitarios como de no universitarios, tanto de quienes sostienen abiertamente que desean el regreso de los militares como por parte de quienes sostienen que nunca más debe suceder eso, de aquí que sus testimonios sean descriptos como "de "reivindicación implícita"', puesto que señalan que no desearían un nuevo gobierno militar pero, al mismo tiempo, expresan disgusto hacia la democracia y aprecio y añoranza hacia el gobierno militar, comparándolos y diciendo preferir el "orden", "respeto" y la "seguridad" que "existía antes", incluso que les gustaría que los militares vuelvan pero esta vez "sin pasarse de la raya", o "únicamente ocupándose de la seguridad". Cabe destacar que estas tres palabras: "seguridad, orden y respeto" se repitieron constantemente en los testimonios de las y los entrevistados y se utilizan para describir el periodo militar, si bien las/os entrevistadas/os con estudios universitarios acompañaban esa frase con otras tales como: "a costa de violar derechos humanos". Veamos un testimonio no condenatorio férreo, correspondiente al de una persona no universitaria, pero que sintetiza al resto de los testimonios de "reivindicación explícita":

"Yo me pregunto diariamente ¿Quédemocracia? Puedo salir a hablar, pero ¿quién me va a escuchar? ¿Cuál es la diferencia entre gobiernos militares y civiles? ¿Hoy no muere gente? Hoy el Estado mata de otra manera, con la inseguridad... los ladrones entran y salen de la cárcel ahora". (Entrevista a Laura Céspedes. 23 de diciembre de 2014, Corrientes Capital).

Veamos un testimonio de una persona universitaria, usualmente expusieron cuestiones muy semejantes a la siguiente:

"Lo bueno de ese tiempo era que estudiabas tranquilo. Pero era otro tipo de seguridad el que se disfrutaba en aquella época. Ahora hay muchos asesinatos, pero no vienen del estado. Los militares mataban, aunque no tuvieran la certeza de que fueras guerrillero. Eso es un genocidio". (Entrevista a Domingo Quiroz, 22 agosto de 2013, Corrientes Capital).

Para la "gente decente" todas las batallas que no se relacionen con sus batallas individuales simplemente resultan extrañas, para "desconfiar". Esto último solo deja de concordar con los 
universitarios que tienen aspiraciones políticas, en su mayoría pertenecientes al partido radical de Corrientes. Al mismo tiempo se visualizan las diferencias económicas como "naturales" y se mencionan frases tales como "Dios sabe lo que hace". Es decir, las reivindicaciones por las cuales luchaban los partidos de izquierda no solo nunca fueron conocidas por un gran número de las/os correntinas/os entrevistadas/os, sino que además fueron tachadas de "injustas" por algunos entrevistados que dijeron sí entender los ideales de los subversivos, veamos las palabras usadas por un entrevistado:

"Los guerrilleros te hablaban de "igualdad" y todas esas cosas, pero hay igualdades que no se pueden defender, por ejemplo, yo soy empleado acá, empleado raso, vos sos una profesora, vos estudiaste y te sacrificaste, y ellos tienen esa cosa de que vos y yo tenemos que ganar igual y no es así (...)". (Entrevista a Juan Erro, 20 de diciembre 2015, Corrientes Capital).

Paralelamente, existe, sobre todo en los no universitarios, el imaginario de que "la política es cosa de entendidos", que ellos "no tienen tiempo para esas cosas porque tienen que trabajar". Asimismo, el trabajo es visto como la demostración de su dignidad, pintando a la política como una cuestión de corrupción a la que solo acceden "quienes tienen la vida resuelta". No obstante, se describe con gestos de desaprobación a las/os jóvenes que fueron guerrilleras/os por no poseer "la dignidad que te da el trabajo", mientras que los militares son considerados como lo contrario a este dis-valor. Con respecto a este punto podemos destacar una conexión entre pasado y presente, muy persistente, que se realiza en los testimonios: se relaciona, en la actualidad, a entregar y recibir planes sociales como un claro y aberrante ataque a "la cultura del trabajo", a "la cultura del esfuerzo" las cuales son virtudes dignas de la "gente decente". Se señala con frecuencia en las entrevistas que "la gente ahora no quiere trabajar porque existen planes sociales" y "que las mujeres se embarazan por un plan social". Este "escandalo" se relaciona con la democracia y los gobiernos kirchneristas, pero también habla de una "cultura del esfuerzo" que dejó de existir entre la población, esas/os "planeras/os son quienes delinquen y quienes entran y salen de las cárceles impunemente", algo que "jamás hubiera sucedido en la época de los militares, porque ellos no lo hubieran permitido". Una vez más podemos notar como se coloca al gobierno militar como el garante de la "vida decente", constituyendo este uno de los grandes motivos por los cuales las/os entrevistadas/os reivindican al período militar y hasta desearían que regresen al poder. 
Veamos un testimonio:

"Mi familia era de clase media, gente trabajadora, que estudiaba. Nosotros éramos trece hermanos y ninguno tuvo problemas con militares ni policías. Hoy la clase media está casi desaparecida, los que antes eran de clase media hoy no buscan trabajo porque tienen planes sociales y no trabajan. La gente no puede vivir de un plan, mientras que los que no tenemos planes tenemos que trabajar" (Entrevista Anónima, 3 de septiembre de 2012, Corrientes Capital).

"La gente común, de aquella época, prefería a un militar antes que a un guerrillero. “Montonero" era una mala palabra. Veías a un soldado y te sentías protegida. La delincuencia no existía, comenzó con la democracia. Hoy vivimos un caos. Con la democracia se perdieron valores fundamentales como el respeto y la cultura del trabajo" (Entrevista Anónima, 20 de septiembre de 2012, Corrientes Capital).

Si realizamos una rápida comparación con los Testimonios Condenatorios (el otro 45\% de las entrevistas realizadas), al momento de explicar quiénes eran perseguidos por el gobierno militar en la década del setenta, hacen referencia a: "todos los que pensaban diferente al gobierno, pertenezcan o no a organizaciones de izquierda" y se expresa absoluto rechazo a las políticas autoritarias del gobierno de facto. Se menciona como parte de las personas desaparecidas a: políticos, doctores, abogados, profesores, artistas, periodistas, escritores, filósofos, etc. En otros términos, el foco no estuvo en descalificar a quienes fueron perseguidos por los militares, sino en este propio hecho, más allá de que no se comulgara con ideologías de izquierda -únicamente un pequeño porcentaje de los entrevistados dijeron pertenecer al peronismo y a agrupaciones de izquierda, todos ellos son universitarios-.

En Corrientes los dos partidos políticos más numerosos y tradicionales son: El Partido Autonomista y el Partido Liberal. Ambos de ideología liberal-conservadora, de "centro-derecha". Si bien el Partido Justicialista es muy numeroso en la provincia, si sumamos los afiliados de los partidos de centro-derecha lo superan en número ${ }^{4}$.

\footnotetext{
4 "Con los datos aportados por la Cámara Nacional Electoral correspondientes al cierre del segundo semestre del $\underline{2016}$, Corrientes estaba entre las provincias con mayor cantidad de afiliados a partidos políticos respecto del padrón electoral. Se ubica segunda en este listado. Sucede que hacia finales del año 2016 el Padrón Electoral de
} 
Ideales de gobierno

Con respecto a los imaginarios sociales que se refieren a la cuestión política o al "ideal de gobierno", podemos señalar la presencia, en líneas generales, de dos posturas. La primera (la cual no fue el foco de nuestra investigación, pero que cabe ser caracterizada en líneas generales a modo de comparación-contraste) se corresponde con quienes poseen Testimonios Condenatorios hacia el gobierno militar, quienes defienden la democracia como sistema de gobierno y evitan mencionar cualquier tipo de "aspecto bueno" sobre el período, inclusive, en un gran porcentaje ni siquiera hacen referencia a la cuestión de la seguridad en cuanto a la delincuencia.

Por otro lado, se halla el grupo de los Testimonios No Condenatorios. En este grupo prevalece una noción antidemocrática, de descreimiento de los "beneficios" de vivir bajo este sistema. La democracia es asociada con corrupción, inseguridad y drogas:

"Prefiero mil veces aquella época de respeto, seguridad, normas de conducta a este libertinaje que se llama democracia" (Entrevista Anónima, 5 de junio de 2012, Corrientes Capital).

Relatos similares a este se han repetido en varias entrevistas, por mencionar otros ejemplos:

"Prefiero que vuelvan los militares en vez de una mala democracia, así podemos dormir tranquilos como antes, ahora nuestra casa es una cárcel, llena de rejas y si salimos no sabemos si volvemos" (Entrevista Anónima, 9 de octubre de 2012, Corrientes Capital).

\footnotetext{
Corrientes era de 835.437 personas, de las cuales 375.426 (el 45\%) se encontraba afiliada a alguna fuerza política. Hace 10 años, este mismo ranking era liderado por Corrientes que tenía el 54\% del padrón unido a algún partido. De 36 partidos políticos de Corrientes con jurisdicción nacional, hacia el fin del 2016 hay 29 que no superan los 4 mil afiliados (...). Quien más afiliados tiene es el Partido Justicialista con 103.383. Segunda está la Unión Cívica Radical con 76.741. Luego llegan los partidos provinciales más tradicionales como el Liberal (55.459), Nuevo (21.396) y Autonomista (17.213). El PRO cuenta con 5.198 afiliados." Extraído de https://www.ellitoral.com.ar/corrientes/2017-8-17-1-0-0-corrientes-cuenta-con-mas-de-40-partidos-pero-muypocos-de-relevancia-politica-y-territorial. Consultado en agosto del 2018.
} 
"Ojalá vuelva todo eso ahora, para que no haya la droga, yo prefiero los militares y no que vayan a drogarse y que te maten por dos pesos" (Entrevista Anónima, 10 de octubre de 2012, Corrientes Capital).

Es importante señalar la conexión que existe entre esta descalificación hacia la democracia con el "ideal de ciudadana/o" descriptos párrafos más arriba. En los relatos de las/os entrevistadas/os se relaciona a Néstor y Cristina Kirchner con la subversión de los setenta, los cuales "para conseguir votos regalan plata a vagos que no se la merecen". De esta forma, se puede captar el siguiente imaginario social: los "indecentes" de los años setenta gobernarían en la actualidad, desfavoreciendo la cultura del trabajo, usando "el curro de los derechos humanos" para favorecer a delincuentes y castigando únicamente a los militares por lo sucedido durante aquellos años, mientras que fueron los militares los gobernantes que representaron a la gente decente". Esto, como veíamos anteriormente, destaca una conexión entre pasado y presente, característica central de la memoria social.

En los relatos, las autoridades y los militares son garantes del "orden social" (expresión utilizada por las entrevistadas/os tal como siempre lo hicieron los militares), y la principal función de un gobierno debe circunscribirse a que exista "seguridad", seguridad en cuanto a evitar la delincuencia. El "ciudadano decente" solo necesita eso: "seguridad" para llevar adelante su vida cotidiana, los problemas económicos que existieran solo se relacionan con la corrupción y si falta dinero solo "hay que trabajar más"; los subversivos no trabajaban, "eran nenes de mamá, no sé sabe qué querían lograr con las locuras que hacian" (Entrevista a Jorge Sanabria, 23 de julio de 2015, Corrientes Capital).

Otra cuestión que nos resultó interesante fue el hecho de que en ninguno de los relatos se recordó la crisis económica que se vivía en los años dictatoriales, veamos un ejemplo de los precios de 1979, a partir de un recorte periodístico tomado de uno de los diarios tradicionales y de mayor tirada (desde la década del setenta) en la Ciudad de Corrientes ${ }^{5}$ :

${ }^{5}$ Diario “Época”, domingo 2 de septiembre de 1979, Corrientes Capital. Edición número: 1877. 


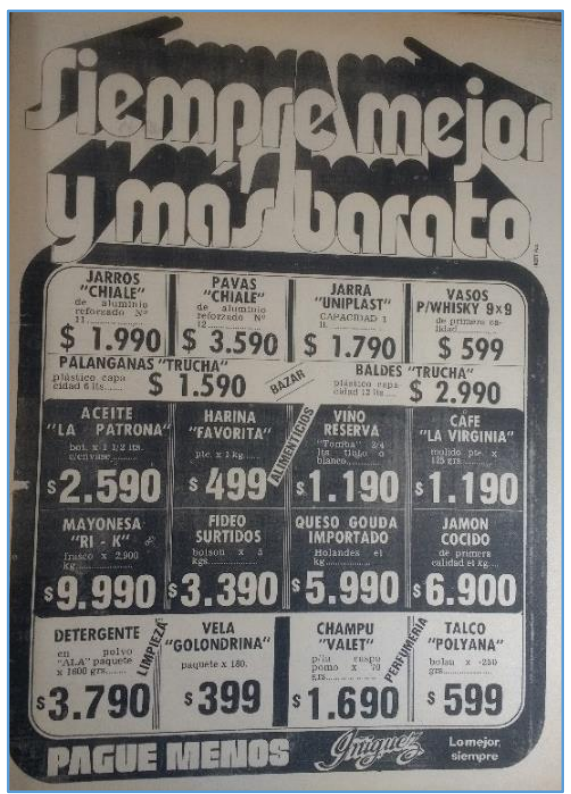

En el recorte periodístico podemos observar que una botella de aceite tenía como costo: $\$ 2,590$; un detergente: $\$ 3,790$; una mayonesa: $\$ 9,990$. Resulta interesante destacar que en ninguna entrevista fue mencionada la inflación. Según Ferrer (2010), el régimen militar concluyó con un aumento de precios del $450 \%$ en 1983. No obstante, cabe destacar que, en comparación del gobierno alfonsinista, cuando la inflación fue del 5000\% en 1989, los números anteriores no presentan mucho impacto; quizás por este motivo la democracia es relacionada con decadencia económica y la dictadura con bonanza económica. En las entrevistas se repetía que "en aquellos años con un trabajo modesto -no universitario- podías acceder a una casa e inclusive a un auto".

Por otra parte, se reitera en las entrevistas que "los militares hicieron obras de infraestructura que nadie más hizo". Tampoco se recuerda al gobierno militar como corrupto (debemos destacar que contemporáneamente a la realización de muchas de las entrevistas (las realizadas desde 2013 en adelante), en los medios masivos de comunicación se hablaba de "la ruta del dinero K" (entre otras cuestiones) casi constantemente.

Los Testimonios No Condenatorios hacia el último gobierno militar se caracterizan por exhibir, desde el aspecto político, un claro desprecio hacia la democracia o hacia la versión de la democracia de los gobiernos kirchneristas. El motivo: se relaciona a la democracia con la inseguridad, la delincuencia, los gobernantes corruptos, el libertinaje, crisis económica, la falta de respeto a los mayores y a las instituciones, la droga, la violencia, la altanería, la impunidad y la 
pobreza. No es de interés en esta investigación indagar cual es el grado de "verdad" o cuál es el rol que juegan los medios de comunicación en este asunto (entre otras posibles variantes); sino describir estos imaginarios sociales y sus conexiones con los imaginarios que se poseen acerca del gobierno militar. En contraposición a la democracia, el período militar será recordando mediante la evocación de cuatro palabras persistentes en todos los discursos: "seguridad, orden, tranquilidad y respeto." Debemos destacar, sobre todo, la palabra "seguridad" que fue la que más se repitió. Al respecto nos decía un entrevistado:

"Hoy la democracia solo es democracia porque no están los militares, pero la inseguridad es terrible, para mis estos años populistas fueron terribles.” (Entrevista a Juan Erro, 20 de diciembre de 2015, Corrientes Capital).

Cabe señalar que en los relatos las/os entrevistadas/os entienden por "populista" al gobernante "que regala plata para ser votada/o".

Otra frase transversal a los testimonios que intentaban no descalificar a la democracia fue la siguiente: “es que no sabemos vivir en democracia”, veamos un ejemplo:

"Que vuelvan los militares, eso quiero, por la inseguridad principalmente. Pues no sabemos vivir en democracia”. (Entrevista Anónima, 3 de noviembre de 2012, Corrientes Capital).

"La democracia, en la actualidad, es un libertinaje. Nos fuimos al otro extremo. La sociedad actual tampoco sabe convivir. Antes había mucha disciplina, muchos valores, hoy ves a maestros y alumnos rompiendo reglas. " (Entrevista a Miguel Angel Romero, 13 de septiembre del 2013, Corrientes Capital).

“... El problema es que nosotros no sabemos vivir en el pluralismo, porque no hay una “democracia”. Hasta hoy hay perseguidos politicos.” (Entrevista a Aurora Pino, 20 julio del 2014, Corrientes Capital).

Por otro lado, quienes expresan contundentemente que desean el regreso de los militares al poder señalan que "es preferible el gobierno militar antes que esta mala democracia". También se 
repitieron entre ellos frases como: "la democracia no me dio nada, solo me quitó cosas", "la democracia trajo la droga", "ahora no se puede andar tranquilo por la calle", "antes no había planes sociales para mantener vagos", "es necesario que vuelva el servicio militar obligatorio", "si no eras guerrillero vivías tranquilo", "ahora hay más desaparecidos por culpa de la delincuencia y la pobreza", "nuestros gobernantes no nos protegen", "la juventud está perdida entre la droga, la delincuencia, no trabajan ni estudian", "antes nos podíamos sentar en la vereda a tomar mate y ahora no", "ahora vivís con miedo y antes no", "antes había disciplina y paz social”. Veamos un testimonio férreo como ejemplo:

"Los militares empezaron a matar gente, pero eso fue por culpa del asesinato de militares. Mataban porque tenía que hacerlos hablar, sí o sí tenían que hablar, no como ahora que vos te vas preso y decís lo que vos querés y lo que no querés no. Ahora la vida es "yo hago lo que yo quiero yo digo lo que yo quiero". En los tiempos de los militares eso no pasaba, estabas tranquilo, te ibas solo a tu casa, a bailar y nadie te hacia nada y ahora no podés salir un paso de tu casa porque ya te están secuestrando, violando. Eso con los milicos no pasaba. Los militares eran mejor que los de ahora. Eran más sanos” (Entrevista Anónima, 19 de abril de 2013, Corrientes Capital).

Si comparamos las expresiones utilizadas en los TNC de "reivindicación explícita" podremos notar una similitud muy contundente con los TNC de "reivindicación implícita", la cuestión de la seguridad:

"Yo apoyo la democracia, pero quisiera que el tema "seguridad" sea manejado por los militares. En la actualidad los policías son impotentes porque saben que si ponen preso a un delincuente éste sale al otro día. " (Entrevista a Miguel Angel Romero, 13 de septiembre del 2013, Corrientes Capital).

"La democracia es el estado ideal. Considero que el ejército debe tener participación en la seguridad, no como en la actualidad que las Fuerzas Armadas estan desarmadas (...)", (Entrevista Anónima, 22 de agosto del 2012, Corrientes Capital).

"Yo optaría por un gobierno democrático que tome los aspectos positivos del gobierno militar en cuanto a la seguridad”. (Entrevista Anónima, 15 de marzo del 2012, Corrientes Capital). 
Otra de las diferencias entre las personas entrevistadas que expresaron Testimonios No Condenatorios, reside entre universitarios y no universitarios con respecto a la expresión de deseo de un nuevo gobierno militar en la actualidad. Mientras que los universitarios no utilizan esas expresiones y dicen "preferir la democracia", quienes no dudaron en expresarlo fueron personas sin estudios universitarios, incluyendo a algunas/os docentes de enseñanza primaria. No obstante, como pudimos observar, fueron muchas las frases de reivindicación del accionar militar o del período militar transversales entre ambos grupos. Sin embargo, cabe destacar que la preocupación por la inseguridad se observó más profunda entre los entrevistados no universitarios, estos últimos lo mencionaron usualmente como "al pasar", mientras que quienes pertenecen a grupos sociales menos favorecidos plantearon esta premisa como un aspecto fundamental y sus tonos de voz dejaban votar mucha angustia y enojo.

Si pensamos a la categoría "discurso de la decencia" desde la Ciencia Política, podemos observar un claro acercamiento a una postura política conservadora inscripta en los TNC. Pero, ¿qué es ser conservador?

“Tomando como base las ideas de Ángel Rivero (1998), William Harbour (1985) y Michael Oakeshott (2000), diremos que el liberalismo conservador es una variante del liberalismo que 1) valoriza la experiencia sobre la teoría y es contraria al racionalismo (es decir, a las abstracciones y a las idealizaciones, lo que comporta, en general una antropología más bien pesimista), 2) es moderada y prudencialista en cuanto al cambio social, 3) se opone a las redistribuciones progresivas de los bienes y recursos, pero no a la acción estatal que garantiza un orden, orienta a la economía y protege los derechos. Además, se trata de una tradición que se muestra 4) temerosa de la democracia (por sus tendencias populistas y por entrañar el peligro de desembocar en una demagogia o en una tiranía de la mayoría) y 5) respetuosa de la sabiduría de las tradiciones e instituciones heredadas (a las que se siente obligada a restaurar cuando son atacadas de modo sistemático por factores exógenos). (...) Por otra parte, el liberalismo-conservador cree en la importancia de un orden social de tipo jerárquico y, aunque comparte la idea liberal de libertad, cree que sus límites deberían ser fijados mucho más estrechamente que lo que habian sostenido los liberales (Harbour, 1985). Según ha sido establecido por ciertos historiadores y politólogos argentinos, la ideología que asumieron las elites gobernantes argentinas 
después de la batalla de Caseros puede ser identificada como liberal conservadora (por ejemplo, Gallo, 1980; Gallo, 1987; Gallo y Cortés Conde, 1986; Botana, 1984; 1991; Halperín Donghi, 1987; Botana, 1985). (Sergio Morresi, 2010).

Transcribimos esta cita de Sergio Morresi (2010) para comprender, de manera general, qué es la ideología liberal-conservadora, entendiéndola como la que predomina en Argentina desde la Batalla de Caseros. ¿Qué tiene que ver esta descripción ideológica con la cultura de la decencia? De hecho, si nos detenemos a observar las frases que sostienen a esta categoría, las cuales surgen de las entrevistas realizadas para este trabajo de investigación, podemos hallar muchas similitudes entre ambas.

Pasando en limpio: "el discurso de la decencia" es una visión de mundo conservadora en cuanto:

a- Valoriza la experiencia antes que las ideologías y es moderada en cuanto al cambio social:

"Los guerrilleros te hablaban de "igualdad" y todas esas cosas, pero hay igualdades que no se pueden defender, por ejemplo, yo soy empleado acá, empleado raso, vos sos una profesora, vos estudiaste y te sacrificaste, y ellos tienen esa cosa de que vos y yo tenemos que ganar igual y no es así, que yo haya tenido oportunidades o no eso es la vida, eso hay que preguntarle a dios”. (Entrevista a Juan Erro, 20 de diciembre de 2015, Corrientes Capital).

"Ellos querían implantar un nuevo régimen, pero esa no era nuestra idiosincrasia, no somos un pueblo revolucionario, protestamos, pero no salimos a imponer nuestras ideas, ellos querían cambiar todo, querian pasarla bien. Yo me amargaba en la universidad porque no se podía dar clases, se perdía tiempo y yo no estaba para eso." (Entrevista a Jorge Sanabria, 23 de julio de 2015, Corrientes Capital).

b- Se opone a las redistribuciones progresivas de los bienes y recursos, pero no a la acción estatal que garantiza un orden.

"En la época de los militares, los que no tenían nada que ver con la guerrilla se trasladaban libremente, sin que le molestaran. No habia inseguridad, habia orden: los alumnos concurrían a clase bien presentados y con uniforme (...), se respetaba a todo aquel que tuviera uniforme, hasta al cartero, no te mataban en la calle por un celular, no habia desórdenes ni caos, no habia droga como hoy (...).” (J. G. M., julio, 2015). 
“(...) después viene el gobierno militar y (...) se trataba de poner un orden y hasta los delincuentes se tenían que cuidar, las personas grandes podiamos respirar tranquilos (...). Los militares asumieron para poner orden a la sociedad y andaban atrás de los grupos subversivos. Los movimientos rebeldes y revolucionarios como Montoneros (...) no eran apoyados por la gente, nada que ver, porque sólo trajeron problemas. (...) Yo tenía mi grupo en la facultad y éramos más maduros, nos dábamos cuenta de que los rebeldes querían promover disturbios a gran escala, eran promotores de eso y por eso las autoridades actuaban (...) Nosotros mirábamos todo de afuera. Cuando venía la policía ellos disparaban. (...) En las calles (los militares) pedían documento constantemente, un tiempo hubo toque de queda, hasta a los mozos que trabajaban de noche los llevaban a las comisarías, con bandeja y todo. Pero por otro lado eso estaba bien porque no había robos como ahora, antes de los militares los delincuentes tenían más posibilidades." (Entrevista a Jorge Sanabria, 23 de julio de 2015, Corrientes Capital.)

"Mi familia era de clase media, gente trabajadora, que estudiaba. Nosotros éramos trece hermanos y ninguno tuvo problemas con militares ni policías. Hoy la clase media está casi desaparecida, los que antes eran de clase media hoy no buscan trabajo porque tienen planes sociales y no trabajan." (Entrevista a Mario Gómez, 26 de enero 2015, Corrientes Capital).

“(...) hay que hacer trabajar a la gente y no regalarles plata, quiero que se arregle lo político, los militares, primero que no tienen esa fuerza que tenían antes, los Kirchneristas les sacaron todo, ahora no tienen ni armas (...). La Argentina viene mal hace muchos años, tenemos (...) la democracia, pero solo es democracia porque no están los militares, pero la inseguridad es terrible, para mí estos años populistas fueron terribles.” Los guerrilleros te hablaban de “igualdad” y todas esas cosas, pero hay igualdades que no se pueden defender, por ejemplo, yo soy empleado acá, empleado raso, vos sos una profesora, vos estudiaste y te sacrificaste, y ellos tienen esa cosa de que vos y yo tenemos que ganar igual y no es así, que yo haya tenido oportunidades o no eso es la vida, eso hay que preguntarle a dios". (Entrevista a Juan Erro, 20 de diciembre de 2015, Corrientes Capital).

"Eso de dar planes sociales a las embarazadas es algo cruel, porque las chicas se embarazan para cobrarlo. Los chicos de 16 años que ahora pueden votar no tienen idea de nada de la política y no les interesa tenerla. Yo soy docente y me dicen que están contentos con lo del 
voto porque se pueden quedar a dormir ese día. Por otro lado, en la dictadura la "ca-pa-cidad" en lo laboral se respetaba, aún si no tenían un título. Porque antes había una cultura del trabajo, del esfuerzo”. (Entrevista a Aurora Pino, 20 julio del 2014, Corrientes Capital).

"A nosotros (los militares) siempre nos respetaron los sueldos. Y hoy en día, haciendo el mismo trabajo, sos pobre. En aquel periodo un docente era de la clase media. Hoy una persona con planes sociales gana lo mismo o más que un docente que recién se inicia. Si tuviera que elegir elegiría un gobierno militar, pero sin las cosas que escuché que hicieron y digo "es-cuché”, porque yo nunca vi nada." (Entrevista a Sonia Gutiérrez, 15 de diciembre de 2014, Corrientes Capital).

"Esa época (del gobierno militar) era linda, porque no había problemas. La gente tenía lo que tenía porque trabajaba, no habia avivados, no habia planes que dan lugar a la vagancia. Esos planes le cambiaron la vida a la provincia, los muchachitos ya no estudian, solo esperan los planes." (Entrevista a Ricardo Romero, 2 de marzo de 2015, Corrientes Capital).

"Mi familia era de clase media, gente trabajadora, que estudiaba. Nosotros éramos trece hermanos y ninguno tuvo problemas con militares ni policías. Hoy la clase media está casi desaparecida, los que antes eran de clase media hoy no buscan trabajo porque tienen planes sociales y no trabajan." (Entrevista a Mario Gómez, 26 de enero 2015, Corrientes Capital).

c- Es temerosa de la democracia, por sus tendencias populistas. Es respetuosa de la sabiduría de las tradiciones e instituciones jerárquicas del pasado.

"Lo unico que sé es que en esa época, de los militares, los jóvenes respetabamos hasta el uniforme del correo, respetábamos las familias, pasa que eso salía del propio hogar, nos enseñaban nuestros padres. Y, por último, ahora hay más desaparecidos e inseguridad que en esa época." (Entrevista Anónima, 1 de agosto de 2015, Corrientes Capital).

"Desde mi punto de vista es mejor un gobierno militar y desearía que volvieran, porque hasta ahora ninguno de los gobernantes pudo frenar esta ola de inseguridad que hay en el pais". (Entrevista Anónima, 12 de marzo de 2012, Corrientes Capital). 
"Sí, yo quiero que vuelvan los militares. En la Argentina no tenemos más soldados. Los militares están dominados por los demócratas y desmembrados. En el nombre de la democracia hay mucha hipocrecía en este país y prepotencia, donde si vos no pensas como el otro sos golpista." (Entrevista Anónima, 20 de julio del 2014, Corrientes Capital).

Conviene subrayar que a pesar de estas expresiones conservadoras, los datos obtenidos en el total de las estrevistas no nos permiten hablar de la Ciudad de Corrientes como una ciudad conservadora, la cual es una frase escuchada muy comunmente, inclusive por parte de las/os correntinas/os en sus relatos. En este trabajo descubrimos que quienes desean el regreso de los militares al poder -el $26 \%$ de las y los entrevistados- reflejan en sus discursos nociones y opiniones conservadoras, las cuales hallamos involucradas en el discurso de la decencia. No obstante, esto no puede tomarse como "prueba" de que "Corrientes es conservadora", en cuanto si cotejamos estas entrevistas con las restantes, es decir, con el consiguiente 74\%, la mayoría porcentual expresó claramente "que nunca más deben volver los militares al poder". Ante esta esquematización, ¿podemos decir que Corrientes es una provincia conservadora? Pero debemos sumar un dato: un $29 \%$ expresó el deseo de "no desear que vuelvan los militares al poder", empero en el resto del discurso expresaron eminentemente críticas hacia la democracia y alabanzas hacia el régimen militar, es decir, sostuvieron Testimonios No Condenatorios a pesar de no expresar su apoyo a que los militares regresen al gobierno, convirtiendo de este modo, a los testimonios no condenatorios en un importante $55 \%$ de los discursos. En tal caso, reiteramos la pregunta: ¿podemos decir que Corrientes es una provincia prominentemente conservadora?

Corrientes ha sido protagonista de acontecimientos históricos que nada tienen que ver con la lógica conservadora, tomando únicamente la historia reciente podemos hallar "el correntinazo" de 1969, el cual consiste en una rebelión estudiantil, de sectores medios y populares, llevado a cabo cuando una intervención federal resolvió implementar planes para privatizar los comedores estudiantiles que funcionaban en la Ciudad de Corrientes y Resistencia, lo cual provocó que las diferentes tendencias y agrupaciones estudiantiles universitarias se unieran. Fue entonces que los estudiantes comenzaron a reunirse en grupos, pensión por pensión, eligieron delegados y decidieron realizar protestas con movilizaciones por las calles de Corrientes en dirección al rectorado, la respuesta del gobierno fue la represión, pero las movilizaciones siguieron creciendo y ganando adeptos entre la 
población estudiantil, universitaria, obrera, sindical, graduadas/os, entre otros sectores sociales. Finalmente, a mediados del mes de mayo, en una de las movilizaciones, con su respectiva represión, la policía asesinó al estudiante Juan José Cabral. El rector de la UNNE se vio obligado a renunciar y meses después se producirían en la Argentina el "Rosariazo" y el "Cordobazo" (Zarrabeitia, 2010).

Otro gran acontecimiento que involucra a correntinas/os fueron las ligas agrarias. Formadas en la década de 1960, fueron organizaciones independientes formadas por jóvenes procedentes de la iglesia católica, bajo la conducción de los curas del tercer mundo (Teología de la Liberación). Estas organizaciones incluyen a campesinas y campesinos pobres de Chaco, Formosa y Corrientes. En el caso correntino incluyó a la zona tabacalera de la provincia (Ferrara, 1973). El problema para los campesinos y campesinas que participaron en las ligas agrarias era el régimen de tenencia de la tierra y los salarios extremadamente bajos percibidos por los peones (olivo, 2013). Durante la última dictadura militar muchas de las personas desaparecidas en Corrientes aparecen con la profesión de "agricultor/ra" ("Nunca más", 2006), no obstante, en los diarios de Corrientes, de la década del setenta, no aparecen noticias sobre estos hechos y las/os entrevistadas/os dijeron no "haber escuchado nunca sobre las ligas agrarias".

Asimismo, no podemos dejar de mencionar el año 1999, cuando sectores movilizados de correntinas y correntinos "autoconvocados", acamparon en la plaza central de la ciudad capital de Corrientes, llevaron a cabo protestas, marchas y decidieron tomar el puente "Manuel Belgrano" que une la Ciudad de Corrientes con la Ciudad de Resistencia, camino obligado para cientos de personas que a diario deben pasar de una ciudad a otra. El motivo era el atraso de varios meses en el pago a las/os empleadas/os públicas/os y un gran descontento hacia quienes gobernaban. Las más aguerridas y luchadoras autoconvocadas eran las maestras, se colocaron carpas en la plaza 25 de mayo, que pasó a llamarse "la plaza de la dignidad", el número de carpas superó el numero de 200. Las/os autoconvocadas/os comían y dormían allí. Pero el 17 de diciembre de 1999 una feroz represión, llevada a cabo por la gendarmería nacional, terminó con muertos y heridos, sin poder aplacar las manifestaciones que continuaron durante varias semanas más (Guber, 2002). 
Las "emociones" relacionadas con el período militar y las narrativas acerca de experiencias personales

Las experiencias personales varían entre entrevistadas/os universitarias/os y no universitarias/os. Los primeros, dijeron conocer o haberse enterado de personas que desaparecieron o fueron detenidas y torturadas en la Ciudad de Corrientes, durante el período del gobierno militar. Paralelamente, los no universitarios dijeron no tener ningún familiar, amiga/o ni conocida/o desaparecida/o; si bien ambos grupos manifestaron haberse dado cuenta que en aquellos años había gente que "de repente no era vista de nuevo", aclararon que "nadie preguntaba mucho porque no sabías si había espías". Esta última cuestión, "cuidarse de hablar mal del gobierno o no preguntar mucho por gente que desapareció" no es relatado como una cuestión molesta ni traumática, más bien "como algo que había que tener en cuenta", sobre todo porque en los relatos se repite la frase "yo no tenía miedo porque no andaba en nada raro".

Se hizo presente, de manera reiterada en las entrevistas, en muchos casos con expresiones de gran malestar entre los entrevistados/as, la siguiente frase: "en la época de los militares si no eras un delincuente vivías bien, con tranquilidad, nadie te molestaba, había seguridad, hoy todo eso se perdió, vivís con miedo a salir de tu casa". No obstante, se les preguntó si antes de la asunción de los militares al poder se vivía con miedo a la inseguridad, a lo que respondieron: "no, todo siguió igual, antes de la época de la dictadura Corrientes también era muy tranquila", "lo único que cambió fue que con los militares tenías que cuidarte de no hablar mal del gobierno".

De igual manera, cuando se les consultó si experimentaron atentados en Corrientes Capital antes del golpe militar, el total de las personas entrevistadas respondieron rápidamente: "no, en Corrientes no pasaba nada", "nos enterábamos de vez en cuando de allanamientos a pensiones", "de algún tiroteo entre policías y malvivientes", pero "las cosas graves ocurrían en las grandes provincias, se veía por los diarios o se escuchaba por la radio". Esto lleva a preguntarnos por la certeza que asumen al pronunciar que "un gobierno militar era necesario" y si sus discursos acerca de las causas de la toma del poder por parte de los militares son tomadas de una fuente externa a sus experiencias cotidianas. En esta línea, debemos tener presente que de manera muy coincidente las/os entrevistadas/os también señalaron reiteradamente que "lo único que veían en los medios de 
comunicación eran los atentados subversivos, guerrilleros, pero en las grandes ciudades, porque “en Corrientes no pasó nada eso".

En las entrevistas hubo coincidencias al señalar que ellas/os se enteraban de "lo que pasaba" por la radio, los diarios y, en menor medida, la televisión (sostienen que eran pocas las personas que poseían una), pero aclaran que, de las desapariciones, torturas, campos de concentración, robo de bebés, etc., "se enteraron mucho tiempo después, cuando volvió la democracia". Según sus percepciones, el conflicto sucedió en Buenos Aires, La Plata, Rosario y Córdoba, mientras que en Corrientes no ocurrían atentados y lo único que fue moneda corriente fueron las detenciones temporarias de todos aquellos que no respetaran el toque de queda, usaban barba y pelo largo siendo varón y de quienes circulaban por la vía pública sin documento de identidad. No obstante, las/os universitarias/os sí relataron cambios en su vida cotidiana por las constantes "requisas" que los militares llevaban a cabo en pensiones, buscando a jóvenes universitarios por su nombre y apellido. Cabe destacar que este grupo de entrevistas se encuentran de manera más abundante en el grupo de Testimonios Condenatorios hacia el período militar.

Por otro lado, las emociones que reflejan las/os entrevistadas/os no universitarias/os al recordar cómo era su vida cotidiana durante el período militar son aquellas relacionadas a la calma y contento. Mientras que, contrariamente, las personas que cursaban una carrera universitaria durante el período militar expresan haber sentido "calma, porque no andaban en nada raro", pero a la vez un estado constante de "alarma", porque "te podían llevar preso solo por ser conocida/o de una/un guerrillera/o y/o por ser "compinche" de una/un guerrillera/o y no saberlo". Citaremos a relatos de entrevistados:

“... Nosotros sabíamos quiénes eran los rojos, con ellos no se podía debatir por el cerrojo ideológico y porque ellos te convocaban a luchar por la celeste blanca a pesar de que querían poner una pinturita roja. El solo hecho de ir a una de sus reuniones, por curiosidad, donde ellos eran la palabra cantante ya te podía costar aparecer en una lista, eran en su mayoría estudiantes. En Corrientes siempre había allanamientos en pensiones y encontraban armas. " (Entrevista a Bravo, marzo del 2015, Corrientes Capital).

"Yo vivía en una casa alquilada, en el centro, con otros estudiantes. Una noche nos hicieron un allanamiento. Golpearon la puerta y cuando la abrí me pusieron una arma en 
la cabeza. Éramos tres personas en mi pieza, entraron por la puerta y por la casa del vecino. Cuando entraron nos tiramos todos cuerpo a tierra y juntaron a todos los estudiantes en mi pieza. Nos gritaban "Hijos de puta, no nos miren a la cara porque los matamos", pero en un momento me pidieron que prenda una lámpara que se había desenchufado y, sin querer, miré a uno de los militares y me pegaron por la cabeza. Preguntaban por un amigo nuestro, que no vivía con nosotros. Pero nosotros no éramos militantes, éramos “bocones”. Esa noche se llevaron al mayor de todos nosotros. Cuando salieron de la casa, automáticamente, me fui a la comisaría cercana a buscar a mi amigo que se llevaron. Cuando llegué, la comisaría estaba llena de canillitas, que los militares trajeron para sacarles los periódicos que acababan de salir, allí se exponía en primera plana que el gobernador usaba el helicóptero del gobierno para fines personales. En ese momento escuché que decían por la radio que había un tiroteó en la dirección del “cuervo”, mi amigo por el cual habían preguntado en mi casa pero que vivía en otro lado. El "cuervo" no era montonero tampoco, el problema es que debatíamos de política y los militares tenían espías por todos lados, incluso en la universidad. Cuando pregunté en la comisaría por el muchacho que vivía conmigo y que se lo llevaron nadie me dio bola, hasta que conseguí comunicarme con su hermano que tenía un alto cargo en la gendarmería y al otro día lo largaron. El cuervo fue liberado dos días después, completamente golpeado." (Entrevista a Domingo Quiroz, 22 de agosto de 2013, Corrientes Capital).

Algo peculiar de las entrevistas a personas universitarias es que, al igual que las personas que no fueron a la universidad, repiten la frase "en Corrientes no pasaba nada", aún luego de contar anécdotas como las anteriores. Y, a pesar de las anécdotas anteriores, expresan no haber sentido miedo.

En concordancia con lo anterior, también surgió otra frase transversal: "llevábamos una vida normal, salíamos a bailar y nunca nadie nos molestó", "nosotros no teníamos miedo a los atentados, tiroteos o secuestros, eso parecía una película, algo que sólo pasaba en las grandes ciudades del país", "te enterabas de rumores, pero yo nunca vi nada", "en Corrientes no pasaba nada, esta es una provincia muy conservadora, nadie se mete", "para mí fue una sorpresa enterarme de todo lo que habían hecho los militares, en ese tiempo no se veía nada, supongo que se tapaba todo", "montonero era sinónimo de violento, una mala palabra", "cuando en la tele o en la radio te 
enterabas que alguien había desaparecido, lo que se escuchaba era 'algo habrá hecho", "en Corrientes no hubo atentados, no se tomaron las universidades ni cuarteles", "lo único que sí supimos que sucedió fue el atentado del cuartel de Formosa", "lo que sí pasaba era toque de queda, requisas, tenías que tener tu documento porque te detenían para averiguar tus antecedentes, pero no pasaba la locura de Buenos Aires", "todos veían mal lo que hacían los montoneros, porque mataban a inocentes". Observemos algunos ejemplos de testimonios:

“En Corrientes no eran conocidos casos de bombas u otros atentados. Yo me iba y venía de la facultad y nunca me pasó nada. Sólo una vez entraron los militares a mi casa, buscando a un amigo. Lo que siempre sucedía era que te pedían el DNI por la vía pública. En Corrientes no pasaba nada, para nosotros la subversión pasó desapercibida" (Entrevista a Domingo Quiroz, 22 de agosto de 2013, Corrientes Capital).

"Yo puse un puesto de hamburguesas del 75 al 81 y nunca tuve ningún problema con nada ni con nadie. Yo estoy seguro de que los militares tenían mis datos por ser amigo de muchos guerrilleros, pero a mí nunca me molestaron. Por eso te digo que veíamos todo esto como una película que pasaba en Buenos Aires, Córdoba, Rosario”. (Entrevista a Ramón Daniel A. Guidobono, 20 de diciembre del 2015, Corrientes, Capital).

“El terrorista y el militar tuvieron cosas buenas y malas, ambos querían un país mejor y se eliminaron entre ellos. Pero en Corrientes solo eran bien vistos los militares. Los terroristas se ocultaban a si mismos, porque Corrientes es tradicionalista, "hay que guardar las apariencias”. Somos viejos de cerebro (...). Los montoneros eran mal vi vistos porque se salían del “orden”. Ser tradicionalistas es también delegar todo en el gobierno”. (Entrevista a Aurora Pino, 20 de julio de 2014, Corrientes Capital).

Las diferencias se pueden hallar en los testimonios de algunos universitarios que militaban o simpatizaban con el partido político radical, quienes coincidieron al expresar cuestiones como: “yo me enteré que muchos muchachos eran guerrilleros cuando desaparecieron. Un montonero nunca confesaba serlo", “de política solo se hablaba en la casa”, "a mí nunca me molestaron los militares, pero porque mi conducta era intachable", veamos ejemplos de testimonios:

“Como docente no fui perseguida por los militares, pero mi conducta era intachable. Yo siempre trabajé tranquila, siempre fui sobresaliente. Nunca tuve miedo, pero eso sí: las 
conversaciones de politica eran en familia, fuera de ese ámbito habia quienes te podian señalar con el dedo, porque los que pensaban diferente a los militares eran perseguidos. Pero no tenía miedo ni a los militares ni a los subversivos porque no era una cosa ni otra" (Entrevista Anónima, 12 de mayo de 2012, Corrientes Capital).

"Aparentemente se vivía una vida normal, lo que pasa es que la gente pobre, la gente normal, viví bien porque nadie los molestaba, el problema era, seguramente, con la gente que quería seguir en la política y que no les dejaban". (Entrevista a Ricardo Romero, 2 de marzo de 2015, Corrientes Capital).

Las experiencias de los no universitarios serán diferentes, ellos expresarán frases similares a: "nadie hablaba de política, no era un tema común, eso pasó con la democracia", "no se hablaba de política no por miedo, sino porque nunca se habló de esos temas, eso era para gente entendida", "la gente pobre, la gente normal, vivía bien porque nadie los molestaba, el problema era con la gente que quería participar en la política, con los hijos de, con los nenes bien", "uno se preocupaba solo por el trabajo, por los hijos, por el día a día", "era una época linda, existía la cultura del trabajo, hoy todos quieren planes y no trabajan". Podemos notar como estas/os entrevistadas/os se separan de cualquier responsabilidad con lo que sucedió durante la dictadura militar, como si únicamente contaran las acciones de la ciudadanía y no sus pensamientos. Sucede lo mismo con respecto a las/os militantes de izquierda, no importaban sus pensamientos, sino sus acciones.

Las experiencias personales de las/os entrevistadas/os tuvieron incumbencia en sus relatos en cuanto quienes no perdieron ni familiares ni amigos ni compañeros de trabajo no dicen recordar de manera traumática el período, sino como "un gobierno más", en contraposición encontramos a los universitarios que narran con cierto "enojo" las experiencias personales tales como requisas en mitad de la noche por parte de militares, la pérdida de derechos, entre tantas otras cuestiones.

Pero si hablamos de las experiencias personales que tuvieron las personas entrevistadas cuyos testimonios no eran condenatorios de la última dictadura, tenemos que mencionar las profundas emociones de enojo que expresan cuando se refieren a la cuestión de la inseguridad-la seguridad. Veamos un ejemplo de una fuente oral: 
"En algún punto yo creo que el gobierno militar fue bueno, porque reprimieron a los montoneros, si no hacían eso terminábamos como Colombia." (Entrevista Anónima, 29 de noviembre de 2012, Corrientes Capital).

“En esa época no había terror hacia los militares, el que sentía miedo era por algo. (...) Llevábamos una vida normal, salíamos a bailar y nunca me pasó nada. No conocí ningún desaparecido ni torturado ni asesinado. Yo hablaba con un amigo, ayer justamente, y me decía que la mejor época de su vida también fue durante el gobierno militar. Podías dejar tu casa abierta y no pasaba nada. Hoy hay una inseguridad total. La inseguridad es el defecto de la democracia. El gobierno les hace un lavado de cabeza a los jóvenes con respecto a los militares para que estos no vuelvan más. Los militares tendrán su parte de la culpa, pero creo que echarles toda la culpa a ellos es para lavarle la cabeza a la gente.

“Para mi fueron épocas..., comparando con las de hoy, en democracia, era en cuanto a lo de la seguridad había seguridad, yo salía y volvía a mi casa las 2 de la mañana y nunca un problema, salíamos de bailar y volvíamos a pie y jamás, como hoy en día, te llegaban dos o tres con un arma o que se yo. Ahora, lo que pasaba por ser joven, es que a la misma vez que uno estaba con esa seguridad había otras cosas que pasaban, pero uno no sabía lo otro que pasaba, eso se fue sabiendo después (...). Yo creo que tuvieron, yo no soy de ni una ni otra cosa, pero me parece que ellos en cuanto a actuar contra la guerrilla estaba bien, porque hoy si seguía la guerrilla no sé si hubiésemos sobrevividos nosotros." (Entrevista a Juan Erro, 20 de diciembre de 2015, Corrientes Capital).

"En esa época no había droga, ladrones ni asesinos como hoy que no podemos salir a la calle con cartera ni sentarnos en la vereda con nuestros familiares y vecinos. En esa época los perseguidos eran los guerrilleros y se necesitaba mano dura para que no avancen otras ideologías contrarias a nuestro sentir nacional." (Entrevista Anónima, 9 de octubre de 2012, Corrientes Capital).

"Pudo haber habido excesos, pero los que andábamos por derecha vivíamos tranquilamente, trabajábamos en changas y nos divertíamos, los familiares nos sentábamos en la vereda y todo se desarrollaba en forma normal, por supuesto, si nosotros 
nos portábamos en forma normal. Ahora, en cambio, hay más desaparecidos e inseguridad que en esa época." (Entrevista Anónima, 1 de agosto de 2015, Corrientes Capital)

“(...) A mí nunca me demoraron en ningún lugar, transité libremente porque habia seguridad (...). El militar se prepara para cuidar la República, y en esos años, con el regreso de Perón, hubo jóvenes idealistas manejados por un grupo de delincuentes llamados Montoneros o el E.R.P, que nos arrastraron a una guerra contra hermanos argentinos." (Entrevista Anónima, 27 de julio de 2014, Corrientes Capital).

"Esa época tenía aspectos buenos: se podía transitar tranquilo por cualquier lugar, podías dejar tu casa sola y nadie te robaba y la delincuencia subversiva se fue del país. El que andaba legalmente no era molestado. Además, no habia planes sociales para amontonar vagos y no te mataban por un par de zapatillas, como hoy pasa." (Entrevista Anónima, 7 de septiembre de 2013, Corrientes Capital).

Luego de la lectura de estos fragmentos de entrevistas y teniendo presente las experiencias personales y las emociones visualizadas, podemos pensar en una combinación entre pasado y presente por parte de los entrevistados y entrevistadas, mediante la equiparación de la izquierda revolucionaria de la década del setenta con la delincuencia actual. Ante esta circunstancia, se podría pensar en una dualidad social entre: "los ciudadanos decentes" versus "los delincuentes", ubicando al gobierno como un mero arbitro que debería juzgar y castigar a los segundos. Dicho de otra manera, la concepción sería la siguiente: "durante el gobierno militar, nosotros, los ciudadanos decentes, éramos protegidos de los delincuentes-subversivos, porque nos protegían los militares"; en cambio, "durante los años democráticos, nosotros, los ciudadanos decentes, vivimos con miedo de los delincuentes, el gobierno no hace nada para protegernos y ese invento de los Derechos Humanos solo sirven para proteger a los asesinos, ladrones...", por eso "yo quiero que vuelvan los militares".

Esta visión autorreferencial, no se pregunta por cuestiones políticas, no ahonda en ideologías ni en proyectos de país, no se pregunta por otras cuestiones que pudieran existir por detrás de la escena "decentes-delincuentes" enfrentados en las calles. Asimismo, equiparar a la izquierda revolucionaria de la década del setenta con la delincuencia actual, significa vaciar de contenido ideológico a la primera, representarlos como meros "asesinos que ponían bombas" de modo 
irracional o como "tontos" que se dejaban llevar por "personas que querían imponernos ideas del extranjero".

Otro análisis interesante puede darse a través de la lectura de estas expresiones:

"En la democracia actual existen más muertos que en la época de los militares a causa de la inseguridad". (Entrevista Anónima, 1 de agosto de 2015, Corrientes Capital).

"Yo pondría en una balanza cuanta gente murió en la época de la dictadura y cuanta gente muere hoy en la democracia por la inseguridad (...). Antes la gente moria por las bombas de los montoneros, hoy nadie habla de eso, sólo se habla de los militares y no dicen por qué asumieron los militares." (Entrevista a Mario Gómez, 26 de enero 2015, Corrientes Capital).

"Todo el mundo criticaba que robaban las criaturas, pero hasta ahora hay robo de criaturas. Si vos ves la factura de tarjeta naranja ahí atrás están todos los que están desaparecidos." (Entrevista anónima, febrero 2015, Corrientes Capital).

"Hoy el Estado mata de otra manera, con la inseguridad, con el hambre, con la droga, con la falta de hospitales." (Entrevista a Laura Céspedes. 23 de diciembre de 2014, Corrientes Capital).

Mediante estas argumentaciones podemos observar cómo se produce la reivindicación de la dictadura militar y de su utilización de los mecanismos coercitivos del Estado para, mediante una comparación con el presente, "suavizar" sus crímenes. Se "relativiza" los crímenes del pasado utilizando como ejemplo los crímenes del presente, casi equiparando la muerte proveniente de la mano de delincuentes con aquellas provenientes de las fuerzas armadas y de seguridad del Estado.

A la hora de reivindicar al gobierno militar y hasta pedir "que vuelvan", prima en los TNC la experiencia personal de no haber vivido la represión ni la persecución de manera personal ni haber sufrido la desaparición y/o desaparición de familiares y amigas/os. Mas allá de toda la información que las/os entrevistadas/os pudieran poseer acerca de los crímenes llevados a cabo por los militares estos "datos" no generan un cambio en sus opiniones más profundas, inclusive "dudan" de la veracidad de esta información, porque "nunca vieron nada". El temor del presente, representado por la delincuencia, y el enojo hacia el gobierno de Cristina Fernández parecieran teñir sus 
narrativas y brindar las justificaciones que creen necesarias para reivindicar la dictadura militar. Las experiencias colectivas de quienes sostienen TNC resaltan cierta "añoranza" del pasado relacionada con cuestiones cotidianas tales como "ir a bailar sin miedo", "salir a hacer mandados sin miedo" y "sentarse en la vereda sin miedo". El "miedo" entonces, no se halla relacionado con un gobierno militar sino con "la democracia". Y la represión que llevaron a cabo los militares se reemplaza, en los TNC, por la palabra "seguridad".

No podemos dejar de preguntarnos, como científicos sociales, por la conformación de estas opiniones, por las personas a quienes benefician estas opiniones, por la manera en que se construyeron, por las instituciones o marco sociales que facilitan estas narrativas, por nuevas maneras a través de las cuales se pueda hacer uso de ellas, entre tantas otras cuestiones. Pero estas preguntas quedaran planteadas para nuevos trabajos de investigación.

La cuestión de los derechos humanos

La existencia de los derechos humanos es uno de los aspectos fuertemente criticados en los testimonios no condenatorios, y quizás, el aspecto más inesperado al que nos condujo esta investigación. Son considerados "un invento" moderno que perjudica a las/os ciudadanas/os "decentes". Si bien esta frase es fuerte y controversial, la explicaremos detalladamente.

Para comenzar a indagar en la visión negativa de los derechos humanos, presentes en los testimonios, pensemos una de las frases más repetidas por las personas entrevistadas: "los derechos humanos sólo sirven para defender delincuentes". En esta frase hay una combinación entre el pasado y el presente. En el pasado los "delincuentes" eran las organizaciones de la izquierda revolucionaria. Veamos qué decía al respecto una nota del diario correntino El Litoral de 1979: 


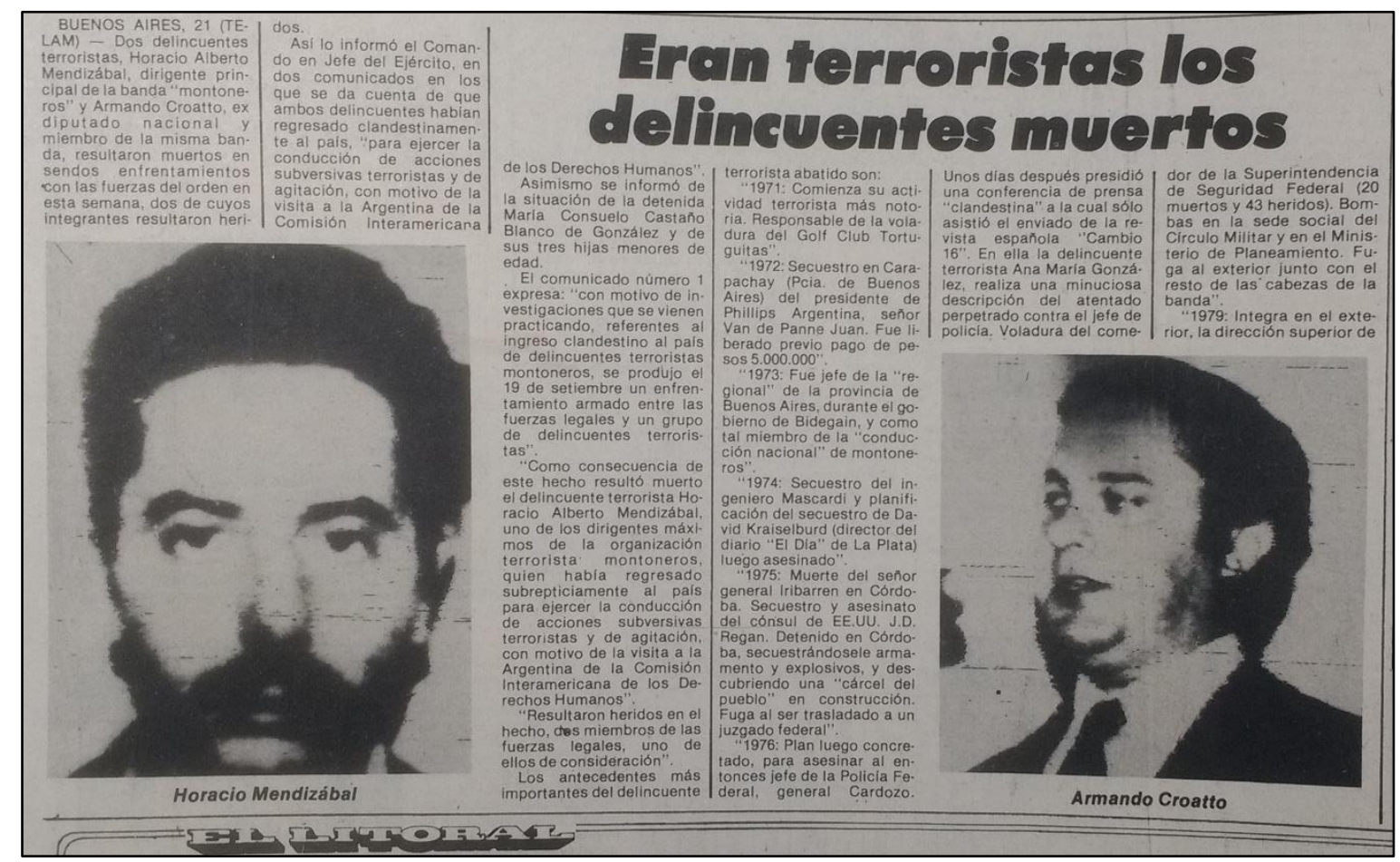

Fuente: El Litoral, sábado 23 de septiembre de 1979, pág. 20.

La nota periodística utiliza la expresión "dos delincuentes terroristas" pertenecientes a "la banda Montoneros", quienes abrían regresado clandestinamente al país "para ejercer la conducción de acciones subversivas terroristas y de agitación con motivo de la visita a la Argentina de la Comisión Interamericana de los Derechos Humanos", volviendo a aclarar que hubo un enfrentamiento entre "las fuerzas legales y un grupo de delincuentes terroristas". Podemos observar como la palabra "delincuentes", "subversivos" y "terroristas" se utilizaban con persistencia para referirse a ese "otro" que no era el Estado.

Por otro lado, el tiempo presente se halla entremezclado con aquellas nociones del pasado, en la frase: "los derechos humanos sólo sirven para defender delincuentes", en cuanto en las entrevistas que realizamos, se estima que "aumentó la inseguridad por culpa de los derechos humanos que protegen a los delincuentes". Da la sensación que existe casi una equiparación entre "delincuentes del pasado" con "delincuentes del presente", con la diferencia que en el pasado eran castigados como "merecían"- y en la actualidad no. La expresión "mano dura" sigue siendo un ideal en los Testimonios No Condenatorios y se la considera como la manera más efectiva de "controlar el 
orden". Los delincuentes deben ser tratados como tales, castigados y no se debe tener consideraciones con ellos. Paralelamente, se culpa al gobierno kirchnerista como el responsable del "degeneramiento de la sociedad", lo cual, según los testimonios perjudica a "los ciudadanos decentes" que no delinquen y que "sí quieren trabajar".

Si pensamos en algunos de los derechos humanos elementales que fueron violados durante la última dictadura militar, como: El derecho a la vida, el derecho a la identidad, a no sufrir torturas ni humillaciones, al juicio justo, a la libertad de opinión y de expresión, etc., podemos descubrir que todos ellos son negados dentro del conjunto de los TNC. En las entrevistas, como ya lo hemos visto, se niega que haya sido, al menos, "injusto" que los "subversivos" hayan sido asesinados por los militares, porque "algo habrán hecho" para merecerlo. Es decir, ante el hecho concreto de la violencia ejercida por el Estado, los TNC levantan un muro de indiferencia o desentendimiento. Bajo estas circunstancias queda claro una de las razonas por la cual la democracia, como forma de gobierno, no cumple con las expectativas de estas/os ciudadanas/os.

En cuanto al derecho de todas las personas de "no sufrir torturas ni humillaciones" en los TNC se menciona que, en este aspecto, los militares "se pasaron", que no tendrían que haberlo hecho, "aunque" era la única forma de "hacer hablar a los subversivos". Es decir, por un lado, se acepta que fue "criticable" pero, al mismo tiempo, se lo consideró como "algo necesario". A la par de esta cuestión se halla el derecho al "juicio justo", lo cual también fue mencionado en muchas entrevistas como "el error" de los militares al no haberlos llevado a cabo. Es decir, en ningún momento se duda acerca la culpabilidad de los "subversivos" ni de la idea de "su merecido castigo", solo se cuestionan "las formas" no democráticas en que los militares actuaron al momento de detenerlos.

En tanto el derecho a la libertad de expresión y de prensa, en las entrevistas se señala que los mismos no existieron durante la dictadura, que "tapaban todo", inclusive se señala que todas las personas "se cuidaban al hablar"; no obstante, tampoco representó un "trauma" en sus vidas cotidianas, sino más bien como una norma más.

Recordemos que, en realidad, es acertado decir que la valorización de la cuestión de los derechos humanos no fue una característica cultural previa al golpe militar y tampoco contemporánea. "En los años setenta no había un discurso pro-derechos humanos, sino un discurso de lógica binaria 
que penetró no sólo en los discursos estatales, sino también en la sociedad" (Calveiro, 2006). La "lógica binaria" a la cual hacía referencia Calveiro tiene que ver con, por un lado, el Estado Argentino y, por otro lado, el "otro" -construido por el mismo Estado- supuestamente amenazador de la nación que era necesario eliminar. Veamos ejemplos de notas publicadas en diarios correntinos de los años setenta que son pertinentes con lo señalado:

Fuente: Diario Época, domingo 16 de septiembre de 1979,

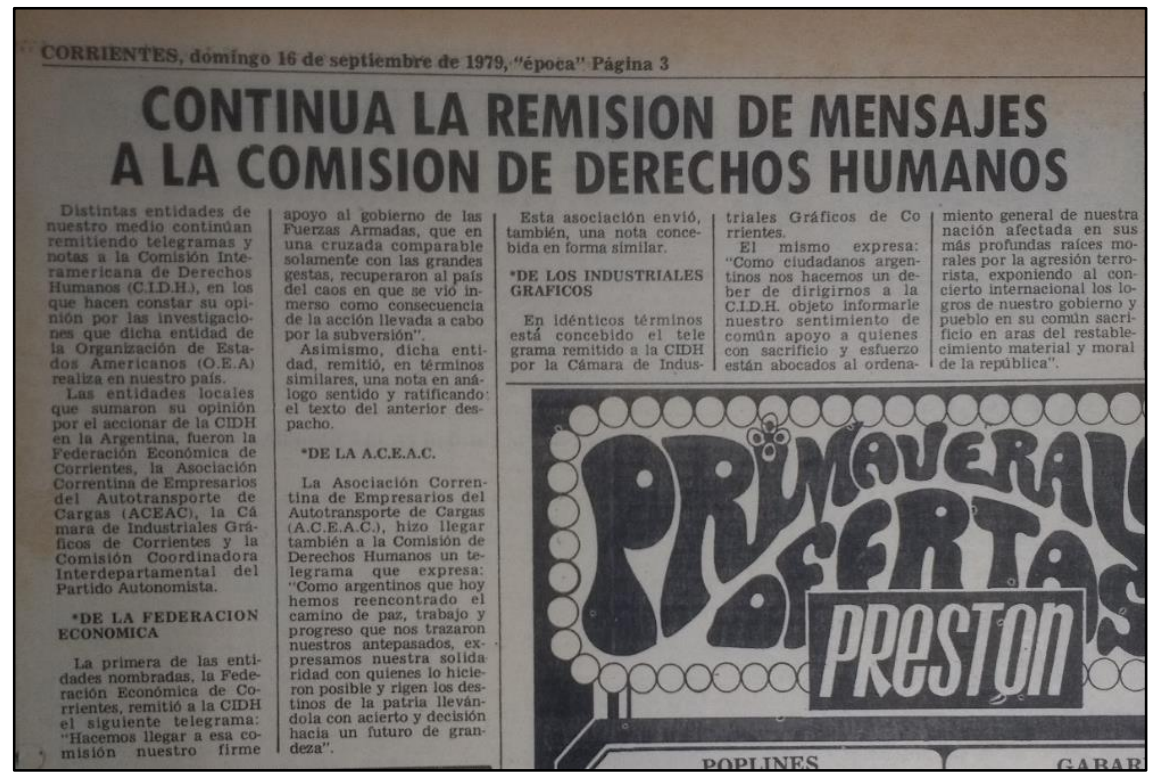

pág. 3.

En la nota precedente se mencionan ejemplos de mensajes remitidos por parte de entidades empresariales correntinas a la Comisión Interamericana de Derechos Humanos que se hallaba en el país para investigar casos de violación a los mismos. En la nota podemos observar como la Federación Económica de Corrientes, la Asociación Correntina de Empresarios del Autotransporte de cargas y los Industriales Gráficos expresaban su apoyo al gobierno militar, el cual, según ellos, 
devolvieron a la Argentina "la grandeza del pasado", "la paz", "el orden", los cuales se hallaban afectados por "terroristas", "subversivos".

Otra expresión escuchada en las entrevistas señala que: "sólo fueron juzgados los militares que torturaron y mataron, pero no los grupos subversivos que hicieron lo mismo". Al respecto, señalaba Catela (2010):

"Pasados treinta años del golpe militar, una de las cuestiones centrales que surgen es el porqué de la imposibilidad de poner sobre la mesa la discusión sobre la violencia política de los años setenta, la lucha armada, los grupos guerrilleros, etc. (...) si el propio discurso de los derechos humanos y la memoria cuestionan la legitimidad de la violencia (...). Este dilema desestabiliza de alguna manera la propia noción de derechos humanos."

Veamos otro ejemplo periodístico de Corrientes durante la década del setenta, en cual ya se hablaba de lo mismo:

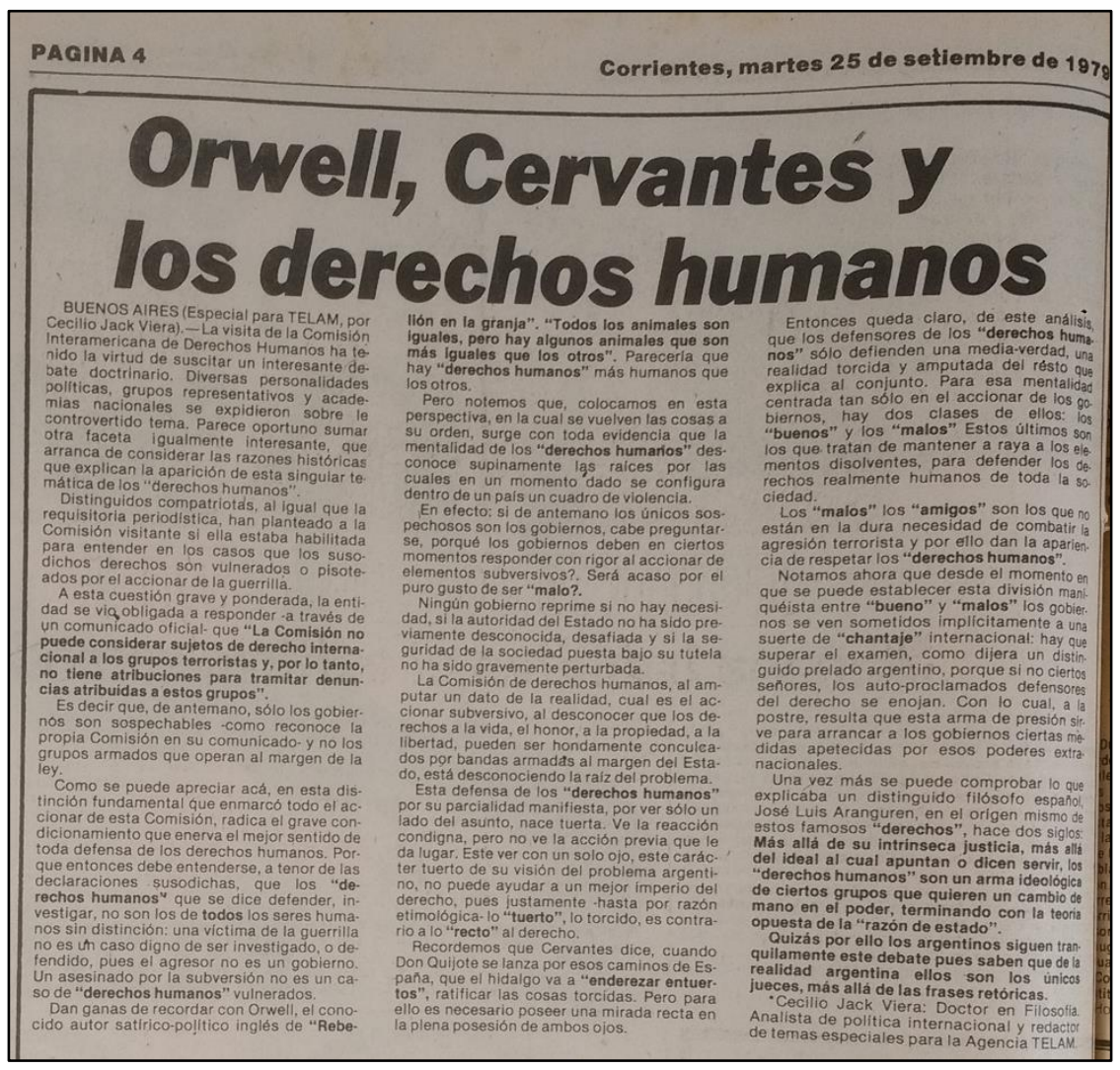

Fuente: Diario El Litoral, martes 26 de septiembre de 1979, pág. 4. 
La nota señala muchas frases muy similares a las escuchadas en las entrevistas, tales como: "los derechos humanos son solo válidos para defender a los subversivos y no para los militares de las fuerzas armadas", y "ningún gobierno reprime si no hay necesidad". En la nota se acusa a la Comisión Interamericana de ver la realidad "parcialmente" y de ser "tuerta", destacando que "lo tuerto, lo torcido, es contrario a lo recto, a lo derecho". Asimismo, se señala en la nota que "los verdaderos derechos humanos de la sociedad" como "la vida, el honor, la propiedad, la libertad" "fueron conculeados por bandas armadas al margen del Estado". Expresiones similares a las hallamos presentes en los TNC.

Al mismo tiempo, en la nota se califica de "arma ideológica" a los derechos humanos, y, en las entrevistas, se los denomina "el curro de los derechos humanos", el "invento de los k", e “ideologías externas". La Comisión Interamericana de los Derechos Humanos, en 1979, hacía la salvedad de que no es lo mismo un civil, un ciudadano cometiendo un delito, como el asesinato, que un Estado nacional. La misma explicación aún hoy no es entendida, al menos en el contexto de los TNC de nuestras personas entrevistadas.

Cabe destacar que estas frases que cuestionan a los derechos humanos en las entrevistas no sólo coinciden con los discursos emitidos por los periódicos de los años setenta sino también se pueden escuchar en la actualidad discursos de la misma índole. En el año 2014 será el candidato a presidente Mauricio Macri quien creó la expresión "el curro de los derechos humanos" en una entrevista brindada al periódico La Nación (Feierstein, 2018).

¿No pasaba nada en Corrientes durante la dictadura?

A continuación, podemos observar una lista $^{6}$ de correntinos y correntinas que fueron detenidas y/o desaparecidas durante la última dictadura militar:

1. Acosta, Héctor Eduardo (Pata): Secuestrado en Paso de los Libres, Corrientes, (Calle Esteban Alissio 792), a la edad de 20 años, el 22 de marzo de 1976.

\footnotetext{
${ }^{6}$ Fuente: "https://www.ellitoral.com.ar/corrientes/2017-3-24-5-3-0-listado-de-las-personas-desaparecidas-encorrientes". Página visitada el 5 de agosto del año 2019.
} 
2. Achar, Carlos (fallecido durante la democracia), su testimonio fue clave para el enjuiciamiento de los ex militares acusados de delitos de lesa humanidad en nuestra Provincia.

3. Aguirre, Juan Carlos: Tito". "Yacaré". Fue el mayor de 3 hermanos. Correntino de Goya, nacido el 10 de noviembre de 1944,". Militares y policías allanaron su vivienda en la calle Piedras $N^{\circ} 710$, el 12 de julio de 1976. Se resistió a balazos hasta su muerte. Tenía 31 años.

4. Aponte, Duilio Fue detenido en noviembre de 1974 hasta el año 1982, el que más tiempo de detención acumuló. Falleció en la democracia.

5. Álvarez, César Héctor (Titi): 31 años. Correntino. Secuestrado-desaparecido el 17 de marzo de 1977 en Capital Federal.

6. Areta, Ignacio (Iñaki): Natural de Monte Caseros, Corrientes, Secuestrado-desaparecido el 29 de junio de 1978.

7. Arce Gómez, Abel: Nacido en la Nochebuena de 1954. Agricultor. Delegado de las Ligas Agrarias Correntinas. Desapareció en mayo de 1977 mientras era conscripto.

8. Areta, Joaquín Enrique "La Rubia" y/o "El Correntino" sabían decirle. Oriundo de la ciudad de Monte Caseros, Corrientes donde nació un 15 de agosto de 1955. Desapareció en Buenos Aires en junio de 1978. Saltó a la notoriedad cuando Néstor Kirchner leyó su poesía "Quisiera que me recuerden".

9. Arqueros, Joaquín Vicente (Bocha): "Juampa". "Bocha”. Nació el 8 de septiembre de 1948. Desapareció el 17 de noviembre de 1976.

10. Artieda, Rómulo Gregorio: Nacido en Bella Vista, Corrientes, el 13 de agosto de 1954. Desaparecido el 14 de mayo de 1977. Sus restos permanecieron en un cementerio de Empedrado durante 30 años hasta que fueron identificados en octubre de 2008.

11. Arrué, Horacio Antonio: “Chueco". Hijo de un legislador justicialista. Licenciado en Economía. 31 años. Desapareció en Tucumán en septiembre de 1976 y murió en Campo de Mayo por las torturas que sufrió. 
12. Ayala, Vicente Víctor (Cacho): Abogado. Nacido en Corrientes, el 1 de marzo de 1946. Fue detenido por la Policía en la esquina de Moreno y La Rioja el 16 de febrero de 1976 junto con otros 3 compañeros.

13. Barozzi, Julio César (Cacho): Nació en Curuzú Cuatiá, provincia de Corrientes el 11 de abril de 1954 y lo vieron por última vez cuando fue detenido por la Policía en la esquina de Moreno y La Rioja el 16 de febrero de 1976 junto con otros 3 compañeros.

14. Benítez Sosa, Adrián: Oriundo de Corrientes, Capital, seminarista, desaparece en Buenos Aires.

15. Belsky Moisés: Oriundo de Monte Caseros, fue uno de los que encabezo en el año 1966 el denominado "Correntinazo".

16. Beláustegui, Juan Francisco: "Pablo". Nacido el 5 de abril de 1936, santafecino, cae combatiendo en la esquina de las calles Teniente Ibáñez y Córdoba de esta Capital el 8 de octubre de 1975.

17. Mirta Beatriz Blanco de Velásquez: Estudiante de Derecho. Militante de JUP y Montoneros. Secuestrada-desaparecida junto a su marido en 1975.

18. Bustos, Miguel Ángel, Cordobés, murió acribillado en Corrientes Capital, el 8 de octubre de 1975 a la edad de 29 años.

19. Bogado Listo Ramón: Desaparecido el 1 de mayo de 1982, tenía 22 años secuestrado en Corrientes

20. Buffa, Arnaldo Haroldo: 43 años de Luján (Buenos Aires). Militaba en el Partido Socialista de los Trabajadores, desapareció junto con su esposa en Paso de los Libres, cuando intentaba salir del país.

21. Castañeda, Jorge Aníbal: de Mercedes. Solamente se tiene el dato de una carta a la madre desde Rosario. Vivía Zárate, Bs. As. En octubre 1975 allanan la casa familiar en Mercedes y lo llevan detenido. 
22. Coutada, Norma: Oriunda de Santo Tome, desaparecida en Zarate, provincia de Buenos Aires. Nacida el 29 de febrero de 1956. Sus compañeros le decían "Lluvia”. Secuestradadesaparecida por la última dictadura militar, el 16 de septiembre de 1977.

23. Coutada, Myriam: Oriunda de Santo Tome, hermana de Norma, tenía 24 años cuando desapareció el 16 de octubre de 1976 en Zárate, Buenos Aires, estudiaba en la UNR, donde militaba en la JUP. Su familia sigue buscando a su hijo.

24. Díaz, Luis Alberto (Lucho): Nacido Corrientes, en la ciudad de Mercedes, el 15 de enero de 1951. Desapareció en Sáenz Peña, Chaco.

25. Duarte, Carlos Alberto: "El Carau": Militaba en la JUP y le faltaban pocas materias para ser contador. Detenido a fines de 1975 y asesinado a los 24 años durante la masacre de Margarita Belén.

26. Ferraz, Manuel: Oriundo de Santo Tome.

27. Fernández, Eduardo: "Lalo". "Gallego". Nacido el 27 de diciembre de 1954 en Córdoba, creció y se educó en Goya, Corrientes. Lo dan como secuestrado y desaparecido el 5 de agosto de 1976, presuntamente murió en la masacre de Margarita Belén.

28. Gauna, Víctor Hugo: Lugar de origen Corrientes, Capital, legajo de la Conadep 942. Desapareció en 1975.

29. Galeano, Pedro Raúl: Le decían “Corrientes” y "El Correntino”. Militante de Juventud Universitaria Peronista (JUP) y Montoneros. Estudiante en la Facultad de Ciencias Económicas de la Universidad Nacional de Rosario. Desapareció en julio de 1976. A los 21 años, fue severamente torturado

30. Figueredo, Raúl Antonio: “Cacho”. "Ginebrol”. "Pedro”. Nacido el 9 de noviembre de 1942 en Alvear (Corrientes). Secuestrado-desaparecido el 30 de septiembre de 1977 en Alvear.

31. González, Alfredo: "Profe". “Gonzalito". Nacido en Bella Vista, Corrientes. Secuestrado a la edad de 39 años, el 4 de marzo de 1978 en calle Sarmiento 213, Posadas, Misiones. 
32. González, Argentino V: (Chaqueño), Secuestrado-desaparecido el $1^{\circ}$ de enero de 1980.

Estaba haciendo el servicio militar obligatorio en el Regimiento de Infantería No 5 (RI5) con cuartel en Paso de los Libres, Corrientes.

33. González, Delicia: Nació en Paraje Cafarreño, departamento Lavalle, Goya, Corrientes, el 22 de septiembre de 1939, asesinada en la "Masacre de Margarita Belén”, Chaco, el 13 de diciembre de ese mismo año, a los 37 años de edad.

34. González, Elpidio: Nació en Loreto, provincia de Corrientes. Maestro rural. Cae en combate -con 28 años- el 13 de noviembre de 1979, estuvo exiliado pero volvió al país.

35. Goyeneche de Sobko, Elida: Oriunda de Goya, secuestrada el 12 de enero de 1978 en el Club de Pesca de Goya "Doña Goya", en presencia de sus hijos. Era docente y estudiante de medicina.

36. Gervasoni, Julio "Cuervo": Oriundo de Itati, nace el 22 de mayo de 1941 y es detenido en Santo Tome el año 1975, cuando ejercía su profesión (abogado) estuvo preso hasta 1982, pasando por varios centros de detención. Falleció en el mes de agosto de 1982.

37. Ibarguren, Justo César: Secuestrado el 24 de agosto de 1976 por fuerzas conjuntas de Ejército, Policía y Prefectura, en la localidad de Monte Caseros. Fue visto con vida por última vez en el campo de concentración denominado "Vesubio".

38. Lomonaco, Víctor Hugo: Oriundo de la localidad de Santa Lucía, desapareció el 8 de octubre en la Ciudad de la Plata, Provincia de Buenos Aires, era estudiante de Arquitectura en la Universidad de La Plata.

39. Martinelli, Pablo Alberto: oriundo de la ciudad de Paso de los Libres y estudiaba en la Facultad de Veterinaria de la Universidad Nacional del Nordeste (Unne). Caído en un enfrentamiento con fuerzas represivas en Resistencia, Chaco, en 1976.

40. Marcón, Carlos Rubén: Nació en Corrientes, en junio de 1980, a los 27 años desapareció en Paso de los Libres mientras intentaba salir del país.

41. Martinelli, Susana de Oliva: nació el 21 de enero de 1953 en Ramos Mejía. Concurrió a la escuela primera en el Instituto del Niño Jesús de Paso de los Libres, Corrientes, donde 
también hizo la secundaria. Desapareció junto a su esposo en agosto de 1976 y hallada muerta, con su cuerpo mutilado.

42. Méndez, Raúl: Nació en Santa Lucía, Corrientes, el 12 de mayo de 1951. En diciembre de 1976 su familia recibió un llamado telefónico: una persona que no se identificó afirmó que Raúl había sido asesinado en la Masacre de Margarita Belén.

43. Meza Marengo, Carlos Alberto, "Ramón": Nacido en la ciudad de Corrientes, el 5 de agosto de 1952. Fue asesinado en la Plaza Once de Buenos Aires en febrero de 1977. Sus restos fueron recuperados recién en el 2000.

44. Moresi, Pedro Francisco: Detenido en Corrientes en diciembre de 1977 junto con su esposa, pero trasladados a Comisaría de Bella Vista, Buenos Aires, donde fueron visitados por familiar antes de su desaparición.

45. Monzón, Roque: Oriundo de Goya, trabajaba en Corrientes Capital y vivía en una pensión. Allí fue secuestrado-desaparecido el $1^{\circ}$ de enero de 1977 a la edad de 30 años.

46. Ojeda, Rodolfo Amado (Poloncho): Dirigente correntino democristiano detenido durante la dictadura militar, profesor en la Facultad de Derecho de la UNNE, abogado de varios compañeros de la JUP, por cuya causa fue su detención. Murió de cáncer en la década del 80 .

47. Oliva, Carlos Alberto (Calú): Nacido en Paso de los Libres, Corrientes, el 4 de febrero de 1951. Fue fusilado en Bahía Blanca en diciembre de 1976 junto a su esposa en un centro clandestino de detención.

48. Olivos, Juan Antonio “Tonito”: Ligado a la Teología de la Liberación. Campesino peronista. Militante y delegado en las Ligas Agrarias de Corrientes, tenía 29 años. Casado. Secuestradodesaparecido en Perugorria en marzo de 1977.

49. Pelozo, Justo José: Nacido el 28 de mayo de 1942 en Tabay, provincia de Corrientes. Secuestrado-desaparecido el 15 de febrero de 1977 en la ciudad de Mercedes.

50. Peralta, Marcelo: 27 años. Tarefero. Secuestrado-desaparecido el 29 de junio de 1977 en un yerbatal, en Gobernador Virasoro, Santo Tomé, Corrientes. 
51. Pérez, Neris Victoriano: 38 años. Tractorista. Secretario adjunto de la Federación Argentina de Trabajadores Rurales y Estibadores (FATRE). Secuestrado-desaparecido el 2 de junio de 1976 en Gobernador Virasoro, Santo Tomé.

52. Pérez Rueda, Carlos (Charli): Correntino, nacido el 24 de enero de 1950. En Misiones, departamento San Ignacio, en las proximidades del cerro Moreno, cae combatiendo, en el operativo habría actuado Aldo Rico.

53. Puntín, Héctor Rolando: Oriundo de Perugorria de profesión tractorista. Visto por última vez en las afueras de Posadas en 1976 y luego reconocido en centro de detención.

54. Razo, Osvaldo José: Oriundo de Curuzú Cuatía, odontólogo que fue secuestrado, torturado y liberado, que falleció ya recuperada la democracia.

55. Ramis, Manuel: Fecha de nacimiento: 01/01/ 1951, en la ciudad de Santo Tomé, Corrientes.

56. Reguera Britez, Yolanda Dolores: Documento de Identidad No 10.568.405. Se "suicidó" en la Punta San Sebastián, según los diarios el 4-6-76. (militante de la Juventud Peronista de Corrientes).

57. Rodríguez, Griselda: También podría ser María Nilda, Oriunda de Monte Caseros.

58. Romero, Orlando Diego: "Tucumano", fue detenido y luego "desaparecido" en febrero de 1976 conjuntamente con sus compañeros "Cacho" Ayala, "Cacho" Barozzi y Jorge Saravia Acuña en la esquina de Moreno y Salta.

59. Romero, Pantaleón: 46 años. Fuertemente ligado a la Teología de la Liberación. Militante peronista en las Ligas Agrarias. Secuestrado-desaparecido el 16 de marzo de 1977 en Perugorría, Curuzú Cuatiá, Corrientes.

60. Schlatter, Miguel Ángel: Natural de Villa Ocampo, provincia de Santa Fe. De ascendencia alemana, nació un 17 de julio de 1950, Es secuestrado-desaparecido a los 26 años, un mediodía del 17 de enero de 1977 en su domicilio del Barrio Luz y Fuerza de Corrientes (Calle Pampa 1471). 
61. Soto, Lila: También conocida como "Julia", "Paula" y/o "Lila". Nacida en Corrientes Capital, el 9 de agosto de 1947, el 10 de diciembre de 1976 fueron cercados por la Federal, en la calle Dorrego 4771 (Rosario) ella murió acribillada embarazada de 8 meses.

62. Saravia Acuña, Jorge: "Mario", "Chino". Nacido en Buenos Aires en 1946. Fue secuestradodesaparecido el 16 de febrero de 1976, a la edad de 31 años, en la localidad de Corrientes con otros tres compañeros más (Ayala, Barozzi, Romero), a la salida del restaurante del Club San Martín.

63. Tomasella, Norma Blanca: Oriunda de Goya, desaparece en febrero del año 1978 en Buenos Aires, estaba en contacto con las hermanas francesas desaparecidas.

64. Repetto, Julio Santiago: de la ciudad de Bella Vista. Médico traumatólogo. Integrante de la Resistencia Peronista. Estuvo seis años preso durante la última dictadura cívico-militar y padeció crueles torturas. Fue presidente del Partido Peronista Auténtico.

65. Vargas, Dora Elena: "Josefina". Nacida el 20 de mayo de 1953 en Saladas, Secuestradadesaparecida en Buenos Aires cuando esperaba el colectivo para ir a su trabajo. Tenía 24 años y un embarazo de 3 meses. Ocurrió el 12 de noviembre de 1977.

66. Vargas, Juan Ramón (Mono): nació en Saladas, provincia de Corrientes, el 6 de marzo de 1955. A la edad de 21 años, fue secuestrado-desaparecido el 20 de noviembre de 1976 en la ciudad de Corrientes. Fue visto mientras estaba en esa condición, en el Regimiento de Infantería 9 de esa ciudad, esposado, tabicado y torturado.

67. Vázquez de Morresi, Nelly: "Tana”. "Gringa”. Nelly Noemí Vásquez de Moresi. Nació el 22 de octubre de 1949, es detenida junto a su esposo el 17 de diciembre de 1977. "Desaparecida" definitivamente el 29 de enero de 1978 en una comisaría de Bella Vista, provincia de Buenos Aires, junto a su marido.

68. Velázquez, Alfredo Rubén: "Beto". "Fredy”. Nació en la ciudad capital de Corrientes el 16 de mayo de 1950. Aficionado a las danzas folclóricas. Trabajador gráfico. caído en el asalto al Regimiento 29 de Infantería de Monte en Formosa, el 5 de octubre de 1975. 
69. Vergara de Buffa, Hilda Zulma: Tenía 37 años de edad, Secuestrada por las fuerzas represivas entre junio y julio de 1976 en Paso de los Libres, Corrientes.

70. Verón, Ángel Roberto: Conocido como "Chino Cejas". - según El Litoral, octubre 1975, detenido acusado de participar en el copamiento al Regimiento de Formosa.

71. Viñas, Lorenzo: (hijo del escritor David) Desaparecido bajo la dictadura militar genocida, el 26 de julio de 1980, al cruzar el puente internacional de Paso de los Libres, Corrientes.

72. Wettengel, Bauer Máximo: (el alemán) Lugar de desaparición es en Corrientes Capital, en junio de 1976, estuvo detenido en el Regimiento 9, le dijeron a su familia que fue liberado, pero nunca volvió a ser visto.

73. Yedro, Roberto Horacio: Cuervo". Nacido en Chaco el 7 de mayo de 1949, En 1974 es profesor de historia del Colegio Pio XI de Corrientes, donde milita en Montoneros. Hecho prisionero, salvajemente torturado y luego asesinado en la "Matanza de Margarita Belén", Chaco, el 13 de diciembre de 1976.

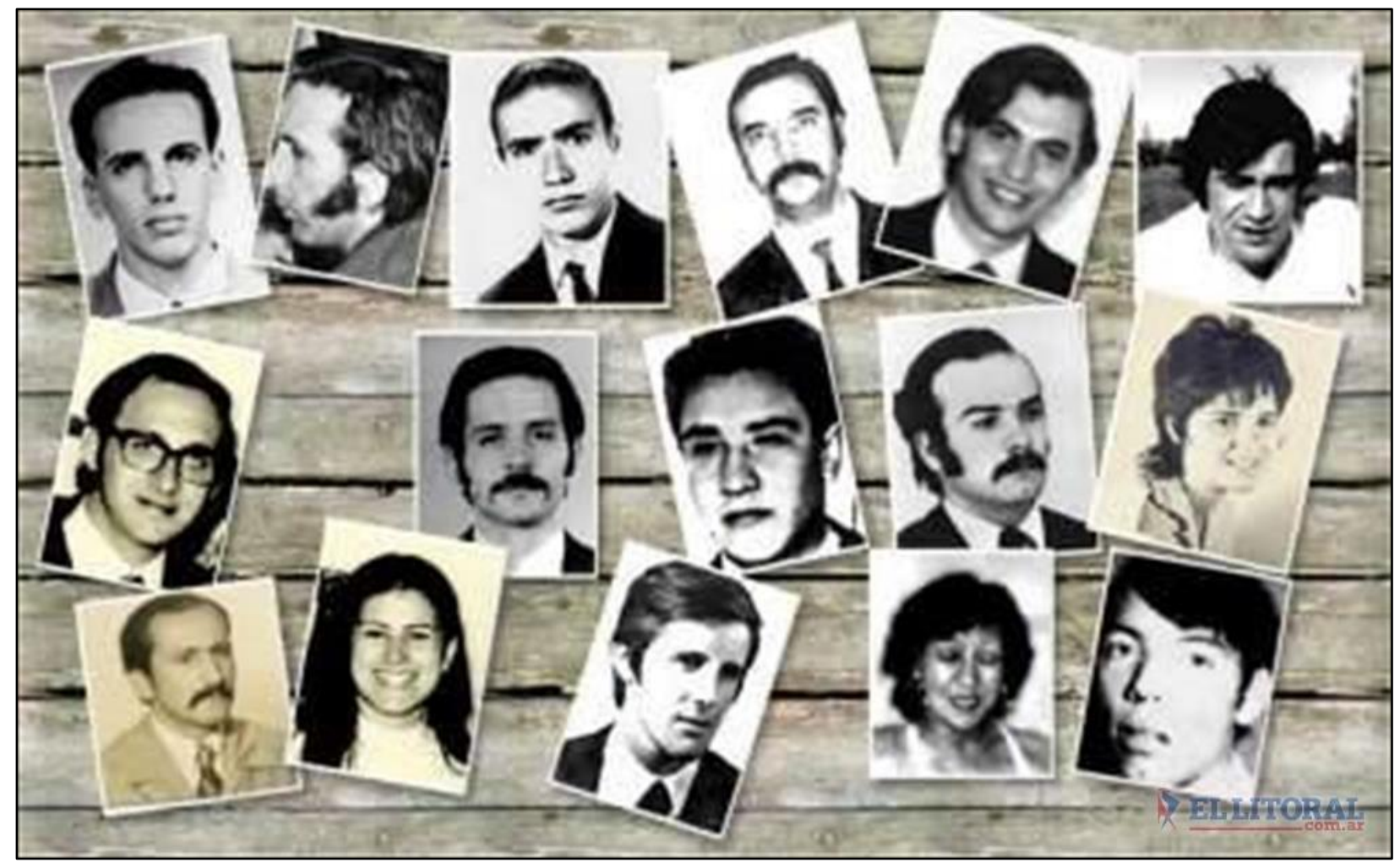

Imagen: desaparecidos/as de Corrientes. Fuente: ellitoral.com.ar 
La lista no está actualizada, fue publicada en marzo del 2017. Se hallaron los cuerpos de otras personas oriundas de Corrientes tiempo después y no sería absurdo pensar que esta lista podría seguir acrecentándose. El diario "Norte de Corrientes" publicaba online ${ }^{7}$ el día 20 de agosto del año 2018 la siguiente información:

"La organización Abuelas de Plaza de Mayo informó la semana pasada que el Equipo Argentino de Antropología Forense (EAAF), a través de la Iniciativa Latinoamericana para la Identificación de Personas Desaparecidas, identificó a dos mujeres embarazadas que fueron asesinadas por el terrorismo de Estado, por lo que sus hijos no llegaron a nacer. Se trata de la correntina Ramona Benítez de Amarilla, nacida en General Paz, y desaparecida el 16 de mayo de 1976, y de Susana Elena Ossola de Urra, secuestrada el 22 de mayo de 1976, ambas embarazadas de 3 meses. Para la Comisión de Derechos Humanos de Corrientes fue una sorpresa, puesto que Benítez no se encontraba en el registro de personas desaparecidas de la provincia."

Analizando la lista de personas desaparecidas de Corrientes, todas ellas con una edad que oscila entre los 20 y 40 años aproximadamente, podemos notar como un gran número de ellas, se encontraban en otras provincias cuando sucedió la desaparición, especialmente en Buenos Aires provincia y Buenos Aires ciudad. Al mismo tiempo, algunas de las desapariciones ocurridas en Corrientes se corresponden con personas oriundas de otras provincias -quizás personas que se hallaban en situación de clandestinidad- y de ciudades del interior de la provincia correntina, en cuanto esta se caracteriza por ser una ciudad universitaria. Solamente 14 personas de la lista fueron detenidas, desaparecidas y/o fusiladas en la Ciudad de Corrientes. Lo cual, por supuesto, a comparación de las provincias y ciudades más pobladas del país es un número bajo.

Entonces: ¿en Corrientes "no pasaba nada"? Muchas de las personas de la lista fueron agricultores integrantes de las ligas agrarias y otras murieron en la masacre de Margarita Belén. Sobre las Ligas Agrarias, existentes en la década de 1970, ya hicimos mención en páginas anteriores, en síntesis, eran organizaciones campesinas que bajo el núcleo de la Iglesia Católica realizaron protestas a causa de las pésimas condiciones de vida que poseían. Si bien este acontecimiento no sucedió exactamente en Corrientes Capital, existieron en Goya (localidad cercana a Corrientes Capital,

\footnotetext{
${ }^{7}$ Fuente: "http://www.nortecorrientes.com/article/122582/el-registro-de-60-desaparecidos-en-corrientes-podriaincrementarse". Página visitada el día 5 de agosto del año 2019.
} 
aproximadamente a unos 226 kilómetros), en Misiones, Formosa y norte de Santa Fe. Por su parte, la masacre de Margarita Belén, localidad chaqueña situada aproximadamente a 35 kilómetros de la capital correntina (apenas cruzando el puente interprovincial Manuel Belgrano) ocurrió en diciembre de 1976, cuando fueron torturados y ejecutados 11 militantes y otros 4 desaparecidos en manos de la policía de Chaco y del ejército Nacional.

¿Por qué sólo se recuerda en las entrevistas el asesinato de Aramburu o el copamiento del cuartel de Formosa, mientras que las/os entrevistadas/os hasta dijeron desconocer la existencia de las ligas agrarias y la masacre de Margarita Belén? ¿tendrá que ver el hecho de que estos últimos acontecimientos tuvieron tratamiento, durante los años setenta, en los medios de comunicación mientras que las ligas agrarias y la masacre de Margarita de Belén no? ¿Tendrá relación con desinformación o con los olvidos de la memoria? Esta lista de personas fue transcripta para mostrar esta cara de la moneda, que, si bien no aparece en los TNC, existió, y su omisión en los relatos tiene tanta importancia como aquello que se recuerda.

\section{Capítulo 5}

\section{Los TNC se contraponen a la memoria estatal kirchnerista}

Memorias del último gobierno militar en Argentina, en general, y en Corrientes, en particular

El tipo de explicación que se asuma por parte del Estado en cuanto al pasado, el tipo de memoria escogida, trae consigo una identidad de nación. Es decir, la historia es politizada y el pasado reciente sigue siendo un objeto de disputa en el presente. El último gobierno militar en Argentina es un claro ejemplo de esas luchas por la memoria y, desde el Estado, las políticas de la memoria defendidas por los diferentes gobiernos, desde la década del setenta hasta la actualidad, ha variado y evidentemente lo seguirá haciendo.

Paralelamente al estudio de los regímenes de memoria estatal y sus variantes, las cuales constituyen "memorias oficiales", se edificaron y edifican "otras memorias", tales como aquellas 
conocidas como "memorias subterráneas" y "memorias denegadas". Para desarrollar este esquema nos serviremos de la autora Ludmila da Silva Catela (2010), quien escribió un artículo acerca de las memorias y los sentidos otorgados a la violencia política de los años setenta, dividiéndolas en tres:

a- Memorias dominantes y cortas que rechazan y denuncian el terrorismo de Estado, representadas por organismos de derechos humanos.

b- Memorias locales (del interior del país), que representan a memorias subterráneas y largas de violencia, las cuales no se encuadran con fechas "nacionales", tales como el golpe de Estado de 1976.

c- Memorias denegadas, están definidas por aquellas memorias que reivindican el papel de las Fuerzas Armadas frente a los "guerrilleros", abogando por los militares muertos en la década del setenta. Estas memorias están representadas por los familiares de los militares asesinados y reclaman "memorias completas" frente a la memoria oficial de los gobiernos Kirchneristas.

Las "memorias dominantes" se refieren a las existentes durante las presidencias Kirchneristas, el período en el cual se realizaron las entrevistas para este trabajo de investigación. Durante estos años, las abuelas y madres de Plaza de Mayo adoptaron una gran visibilidad, importancia y homenajes, se revocaron las leyes de "Obediencia Debida" y "Punto Final", conocidas como la leyes de la impunidad o del perdón, que impedían que los militares responsables de delitos de lesa humanidad fueran juzgados, se retiraron los cuadros de los ex presidentes de facto Rafael Videla y Reynaldo Bignone del Colegio Militar, se crearon museos, se expropió la Escuela de Mecánica de la Armada para transformarlo en un espacio de memoria, se estableció el día 24 de marzo como feriado nacional -motivo por el cual se deben realizar actos conmemorativos en todas las escuelas del país-, se escribieron libros escolares sobre "memoria, verdad y justicia", se fundan archivos de la memoria, los discursos presidenciales resaltaban la condena hacia aquel período señalándola como la más "oscura" de la historia Argentina (entre otros calificativos), se cambió el prólogo del libro Nunca Más para eliminar de él la Teoría de los dos demonios, entre otras cuestiones. 
Según Crenzel (2007) el nuevo prólogo propone una nueva forma de pensar el pasado, ya que contrapone el tratamiento de los crímenes dictatoriales que impulsa el gobierno de Kirchner respecto de sus predecesores constitucionales desde 1983. Asimismo, el autor afirma que este nuevo prólogo demostró, dadas las importantes repercusiones públicas que generó, que el pasado dictatorial sigue latente y que no es un asunto cerrado; que el Estado, como desde 1983, es un actor central en este escenario de luchas por dotar de sentido al período dictatorial.

Es interesante pensar en el intento de eliminación de la teoría de los dos demonios, exponiendo a los militares como el único demonio, en cuanto se subraya, en el nuevo prólogo, que en 1976 la guerrilla ya estaba derrotada. Es fundamental señalar este punto en cuanto hemos notado que los TNC, por una parte, siguen sosteniendo la Teoría de los dos demonios; pero, por otra parte, fijan como único demonio a las organizaciones armadas de la izquierda revolucionaria. La memoria estatal, impulsada por los gobiernos de Néstor Kirchner y Cristina Fernández, desde el año 2003 hasta el año 2015, promovió una condena exclusiva al terrorismo estatal-militar, por ese motivo hablamos de "un demonio". No obstante, el resto de la población, quizás el porcentaje mayoritario, es considerada al margen de la disputa y/o como víctima de un clima general de miedo y terror hacia el gobierno militar.

El hecho de que el Estado Argentino, a instancias de las presidencias de Néstor Kirchner y Cristina Fernández de Kirchner, creara archivos y museos de la memoria por todo el territorio nacional, llevaran a cabo políticas educativas sobre el terrorismo de Estado durante la dictadura y estableciera al día 24 de marzo como feriado nacional, es lo que Catela (2010) denominó "estatización de la memoria". Este concepto alude al "papel central que ocupa el Estado como agente de memoria y su pretensión de generar una política centralizada en la memoria, negando implícitamente la pluralidad de memorias que circulan y son defendidas por diversos grupos e instituciones".

En medio del despliegue de esta política estatal de la memoria, enfocada y denunciante constante del terrorismo de Estado, pudimos hallar en Corrientes Capital "memorias subterráneas": los Testimonios No Condenatorios. Nuestras entrevistas, no obstante, no se realizaron a familiares de 
militares asesinados, es decir, no tomó como muestra a las "memorias denegadas", considerando a estas últimas en los mismos términos que lo hizo Ludmila da Silva Catela (2010).

Ludmila da Silva Catela (2010), desarrolla dos ejemplos de memorias subterráneas, mencionando su experiencia de investigación en el norte argentino, en la provincia de Jujuy, durante el año 2000. Allí descubre que la represión a campesinos, indígenas y obreros no fue un fenómeno circunscripto al período 1976-83, sino que la violencia y la represión tienen raíces más antiguas, en lugares donde las elites locales tienen el poder de mando sobre las fuerzas armadas y de seguridad. Por estos motivos característicos del lugar, las personas entrevistadas no visualizaban el período militar de la misma manera que sucede en ciudades tales como Buenos Aires. En Jujuy las memorias son subterráneas y largas porque están basadas en recuerdos de violencias sufridas a lo largo de muchos años y con características muchas veces diferentes, motivos por los cuales sus representaciones utilizaban sistemas de clasificaciones diferentes a las de "subversivo", "centro clandestino de detención”, "golpe de Estado de 1976", entre tantas otras.

Utilizamos este ejemplo de memorias subterráneas de Catela para incorporar nuestra conceptualización de memoria subterránea, acorde a la situación de la Ciudad de Corrientes en la actualidad. De hecho, nuestro objeto de estudio: los Testimonios No Condenatorios hacia el gobierno militar de 1976-83, constituyen un tipo de memoria subterránea, considerando también a las definiciones de Pollak (2006) de "memorias oficiales" y "memorias subterráneas". Las memorias oficiales están constituidas por la memoria estatal, por "lo dicho", equivalen a las memorias institucionalizadas. Las memorias subterráneas, en cambio, están constituidas por lo "no dicho", por aquellas memorias transmitidas informalmente, de manera simulada u oculta. Las memorias subterráneas se edifican en contraposición a las memorias colectivas nacionales y oficiales, por ende, los reconocimientos caen sobre sujetos divergentes y las disputas por las identidades nacionales defendidas son casi irreconciliables.

Considerando las particularidades de las memorias subterráneas correntinas conformadas por los Testimonios No Condenatorios, podemos hacer una descripción de los puntos de oposición con respecto a las memorias oficiales circulantes durante los gobiernos kirchneristas. Veamos una lista de ejemplo que pudimos construir con base en las entrevistas realizadas y discursos tanto Néstor 
Kirchner $^{8}$ como de Cristina Fernández de Kirchner ${ }^{9}$ y el Prólogo del año $2006^{10}$ del Informe de la Comisión Nacional sobre la Desaparición de Personas.

$\checkmark$ Por un lado, la memoria dominante del período kirchnerista hace hincapié en la existencia, durante el período militar, de un terrorismo de Estado el cual se considera el único "demonio"; es decir: no se menciona la violencia de los grupos de la izquierda revolucionaria (da Silva Catela, 2010). Por su parte, las memorias subterráneas en Corrientes -TNC-, cuando se refieren a la década del setenta, mencionan a un solo terrorismo: el subversivo. Las organizaciones de la izquierda revolucionaria son consideradas, en muchos de los TNC, como el único "demonio", mientras que en otros testimonios persiste la teoría de los dos demonios.

$\checkmark$ El gobierno Kirchnerista buscó fortalecer la lucha por los derechos humanos en cuanto, por citar un ejemplo, reabrió las causas contra militares acusados de haber violado derechos humanos durante la última dictadura militar. No obstante, en las entrevistas que sostienen TNC encontramos un gran descreimiento de la utilidad de los derechos humanos en cuanto se relaciona su defensa con la defensa de criminales, frases tales como: "los derechos humanos solo sirven para defender delincuentes", entre otras, nos recuerda a Feierstein (2018) cuando señalaba que las denuncias de corrupción contra funcionarios del gobierno kirchnerista se extendió a toda su militancia y política, surgiendo la equiparación "kirchnerista igual a chorro", transfiriendo también esta noción hacia las abuelas y madres de plaza de mayo e, inclusive, hacia el recuerdo de la dictadura militar como un período negativo. El punto no es la transparencia o no de todas las organizaciones kirchneristas o de las organizaciones de derechos humanos, el punto es que en las memorias subterráneas la cuestión de los derechos humanos es tomada más bien a la ligera, y se plantea como "justo" "dar su merecido a quien se lo merece y punto", a modo de ejemplo: en las entrevistas se repite la frase "algo habrán hecho" las personas desaparecidas o asesinadas por los miliares, "se lo buscaron", eran "delincuentes". En pocas palabras, para las memorias subterráneas, los derechos humanos van de la mano de la injusticia.

\footnotetext{
${ }^{8}$ Fuente: Discurso de Néstor Kirchner, Diario Registrado, lunes 23 de marzo de 2015.

9 Fuente: Discurso de la presidenta Cristina Fernández de Kirchner en el acto de la Juventud Peronista en el Luna Park Buenos Aires 14 de septiembre 2010.

${ }^{10} \mathrm{El}$ prólogo del año 2006 es tomado como fuente en tanto fue escrito por E. Duhalde y R. Mattarollo, secretario y subsecretario de Derechos Humanos de la nación durante la presidencia de Néstor Kirchner.
} 
$\checkmark$ Al prólogo del año 2006 agregado al libro "Nunca Más" de la CONADEP, se sumaron conceptos que, tal como lo señala Feierstein (2018), buscaba tachar algunos conceptos clave de la teoría de los dos demonios, teoría tan presente entre los imaginarios sociales de las memorias subterráneas. Por ejemplo, podemos notar que en el prólogo del año 2006 se menciona que no se puede equiparar la violencia ejercida por el Estado con la violencia ejercida por ciudadanas/os particulares. Para las memorias subterráneas, en cambio, la dictadura fue "una guerra entre dos bandos igual de violentos". Incluso, en los TNC, se exige que "se los juzgue a los guerrilleros judicialmente tal y como se ha hecho con los militares, porque los dos bandos mataron". Asimismo, en las memorias subterráneas se explica que "quienes empezaron todo fueron los subversivos y que los militares se vieron obligados a actuar para salvar al país"; en cambio, en el prólogo del 2006, se plantea otra causa para la toma del poder por parte de las fuerzas armadas en 1976: la de imponer un sistema económico de tipo neoliberal y acabar con las conquistas sociales de años anteriores, en cuanto, según dirá, la guerrilla ya había sido derrotada militarmente.

$\checkmark$ Para las memorias dominantes kirchneristas la dictadura constituyó uno de los períodos más oscuros de la historia argentina que jamás debería repetirse. Veamos dos pequeños fragmentos de un discurso del ex presidente Néstor Kirchner: "Recordar el 24 de marzo de 1976 es recordar uno de los momentos más dolorosos y más crueles que le ha tocado vivir a la historia argentina en su conjunto", "Nunca más tiene que volver a subvertirse el orden institucional en la Argentina. Es el pueblo argentino por el voto y la decisión de él mismo, quien decide el destino de la Argentina". (Fuente: Discurso de Néstor Kirchner, Diario Registrado, lunes 23 de marzo de 2015). En contraposición, las memorias subterráneas, hacen una lista de las ventajas que tuvieron en sus vidas con el gobierno militar "seguridad, respeto, orden"- y las desventajas de la democracia, acusándola de todo lo contrario "inseguridad, corrupción, drogas, etc.”. Estas justificaciones y reivindicaciones que componen a los TNC llevan, a algunas de las personas entrevistadas, a exclamar que los militares deben volver.

$\checkmark$ Dirá Néstor en 2015: "Quiero dejar en claro que el terrorismo de Estado es una de las formas más injustificables y sangrientas que le pueden tocar vivir a una sociedad. No hay nada, por lo grave que sea, que esté pasando en un determinado momento de la sociedad argentina o de cualquier sociedad, que habilite el terrorismo de Estado"(...) "Los que 
hicieron este hecho tenebroso y macabro, de tantos campos de concentración como la ESMA, tienen un solo nombre: son asesinos repudiados por el pueblo argentino" (fuente: Discurso de Néstor Kirchner, Diario Registrado, lunes 23 de marzo de 2015). Ante esta expresión, las memorias subterráneas presentan otros imaginarios: no se entiende al gobierno militar como terrorista, todo lo contrario, se lo presenta como "el único gobierno que les brindó paz y seguridad", se relaciona al período con "la vida de casas sin rejas", en el cual veías a un militar y sólo sentías "respeto". Los terroristas, para las memorias subterráneas, eran los subversivos-delincuentes.

$\checkmark$ La memoria dominante resalta el papel de la juventud de la década de 1970, hace mención a la "juventud maravillosa" y destaca su compromiso político y social. Veamos otro fragmento del discurso de Cristina Fernández de Kirchner: "Yo formé parte de la juventud maravillosa, de esa juventud que no tuvo la oportunidad que hoy tenemos aquí, de esa juventud que fue masacrada durante la dictadura más terrible de la que se tenga memoria" (Discurso de la presidenta Cristina Fernández de Kirchner en el acto de la Juventud Peronista en el Luna Park Buenos Aires 14 de septiembre 2010). Contrario a todo ello, las memorias subterráneas consideran a los jóvenes militantes de los años setenta como "subversivos", "hijos de papá rico" "vagos que no tenían nada que hacer", "estudiantes crónicos", "loquitos asesinos", "salvajes anti-Argentina", etc.

\section{Funcionamiento de la memoria}

El gran referente para el estudio de memorias, Alessandro Portelli (2016), menciona cuales son los mecanismos de funcionamiento de la memoria; en otros términos, las maneras de situar un acontecimiento en el tiempo por parte de las/os entrevistados. Según el autor, el nivel más elemental se corresponde con la descomposición horizontal, una forma de periodización que consiste en individualizar los bloques temporales homogéneos, marcados por un acontecimiento clave que marcará un "antes" y un "después". Otro nivel más profundo tiene que ver no con el tiempo sino con distintas modalidades de relación con los acontecimientos: 
a- La modalidad "ético-política": correspondiente a la actividad de los grupos dirigentes y de las instituciones.

b- La modalidad "colectiva": hechos naturales catastróficos o políticos, como bombardeos, huelgas, etc. que involucran a un grupo en su conjunto, a su participación colectiva, de base y masas en los hechos "éticos-políticos".

c- La modalidad "personal": se refiere a la esfera individual y familiar, como el trabajo, el matrimonio, muertes, el servicio militar y el involucramiento personal en los hechos “éticos-políticos” o “colectivos”, por ejemplo, despidos o arrestos por razones políticas.

Alessandro lo denomina desplazamiento "vertical" porque los entrevistados tienden a atraer un evento hacia arriba (a la modalidad "ético-política), hacia el medio (modalidad colectiva) y hacia abajo (la modalidad personal). En palabras del propio autor:

“Estas tres modalidades identifican una secuencia de eventos que se superponen, se siguen y se entrelazan con la memoria individual y colectiva y que luego se vierten en la descomposición horizontal." (Portelli, 2016).

Si pensamos cómo representar los Testimonios no Condenatorios siguiendo los enunciados de Portelli descriptos, podemos visualizar el origen de los mismos -como juicios de valor positivos hacia el gobierno militar- en un momento anterior al golpe de Estado de 1976. En las entrevistas se señalan, exactamente, tres acontecimientos como "los iniciadores" del "caos y violencia" que "obligaría" a los militares a tomar el poder:

a- El asesinato del militar y ex presidente argentino Pedro Eugenio Aramburu, el 1 de junio de 1970, por parte de la organización Montoneros, convirtiéndose ésta en su primera acción pública.

b- La "masacre de Ezeiza", del 20 de junio de 1973. Acto multitudinario realizado en ocasión del regreso de Juan Domingo Perón a la República Argentina, luego de haber vivido 18 años en el exilio. En dicho acto, francotiradores de la "derecha peronista" disparará y asesinará a militantes de organizaciones revolucionarias de izquierda, entre ellas: "FAR" y “Montoneros". Durante el acto mismo coronel Perón los había deslegitimado y echado del lugar. 
c- Ataque por parte de Montoneros al Regimiento de Infantería de Formosa en octubre de 1975. Durante el hecho murieron doce soldados del Ejército, nueve integrantes de Montoneros y un policía.

Cabe destacar que no fue recordado por ningún entrevistado el asesinato de personas de las organizaciones de izquierda. Por citar un hecho: La masacre de Trelew de 1972. No se tiene en cuenta la masacre de Ezeiza porque no fue recordado como una tragedia, sino como una anécdota que demuestra que "a los Montoneros hasta el propio Perón los desconoció". La empatía sucede únicamente con los militares y la policía.

Por supuesto, los acontecimientos no son recordados con su fecha exacta y se tiende a mencionarlas juntas, en un mismo período. Como podemos observar, dichos acontecimientos sucedieron antes de 1976. Cuando los entrevistados mencionan estos acontecimientos expresan enojo, indignación hacia el grupo Montoneros y los señalan como los culpables que promovieron el golpe militar. Es decir, el golpe militar, según los discursos -sobre todo de los entrevistados no universitarios-, tuvo un único objetivo y una única causa: evitar que estos grupos "asesinos" tomen el poder en Argentina. Al desconocer sus postulados ideológicos de las agrupaciones de izquierda y/o las políticas económicas de fondo que se tejían por detrás del "caos", se los tacha como meros "violentos irracionales".

Podría señalarse, entonces, que la "empatía" con los militares se estableció con estos acontecimientos, inclusive hasta se podría pensar que el afán en caracterizar al período militar como el período en el cual había "seguridad", "tranquilidad", contrastándolo con el período democrático de los últimos años, se corresponde con cierta asimilación de la "delincuencia subversiva" con "la delincuencia común". Dicho de otro modo, "los subversivos eran delincuentes peligrosos contra los que el gobierno militar actuó como debía", mientras que "en la actualidad los gobiernos democráticos no hacen nada contra la inseguridad provocada por hechos delictivos". Los subversivos eran "estudiantes eternos que se metían en problemas en lugar de ir a estudiar en serio y a trabajar"; paralelamente: "los delincuentes actuales son jóvenes que no quieren estudiar ni trabajar y solo se dedican a tomar y a drogarse; roban, matan y entran y salen de la cárcel como si nada". Esto nos remite a lo que expresaba Portelli (2016) en su libro: 
"El primer aspecto que hace diferentes a las fuentes orales es su capacidad de informarnos, más que de los acontecimientos, de sus significados (...). El interés del testimonio no consiste solo en su adhesión a los hechos sino en su alejamiento de ellos, porque es en este desvío que se insinúa (...) lo simbólico (...)”.

Regresando a los tres acontecimientos que fueron señalados por los entrevistados y pensándolos con los "mecanismos de la memoria" descriptos por Portelli, podemos señalar que serán estos acontecimientos, quizás resumidos en "la violencia ejercida por los Montoneros", como la descomposición horizontal, la cual marcará el "antes" y el "después", lo que provocó la toma del poder por parte de los militares y "lo único" que ellos "vieron" -por los medios de comunicación, porque de la violencia ejercida por los militares "no se supo nada hasta el regreso de la democracia". Es decir, los Testimonios No Condenatorios asumen como hito estos acontecimientos.

En cuanto a las modalidades verticales de los acontecimientos, una parte considerable de los narradores coinciden en señalar a los hechos perpetrados por las organizaciones guerrilleras en la "modalidad colectiva" y a los hechos perpetrados por los militares desde la toma del poder como la "modalidad ética-política", producida como consecuencia de la primera.

Por otro lado, las modalidades verticales de los acontecimientos varían según universitarios y no universitarios en cuanto a la "individual". Los universitarios suman a los relatos una "modalidad individual", puesto que vivenciaron allanamientos a pensiones, tienen conocidos que fueron encarcelados y golpeados, conocieron algún "desaparecido" y dicen haber conocido a Montoneros en la facultad. En cambio, los no universitarios no suman la misma modalidad individual, en cuanto sostienen "nunca haber visto nada" y no tienen conocidos "desaparecidos", muertos o encarcelados por los militares.

"La memoria es la historia", nos dirá Portelli (2016), porque:

"La bifurcación entre hecho y memoria no puede ser atribuida al deterioro de los recuerdos, al tiempo transcurrido o incluso a la edad avanzada de los narradores. Es más bien producto del funcionamiento activo de la memoria social, de procedimientos coherentes que organizan tendencias de fondo subyacentes (...). Más allá del acontecimiento como tal, el hecho histórico relevante aquí es la memoria misma." 
Profundizando estas expresiones, Portelli demarca tres funciones principales de la memoria colectiva a la hora de manipular los acontecimientos, las cuales serán utilizadas para describir los TNC:

a- Función simbólica: la muerte de Aramburu, la masacre de Ezeiza y el copamiento al regimiento de Formosa constituyen los acontecimientos que se convertirán en simbólicos a la hora de adoptar un juicio de valor, a la hora de "justificar" los TNC y dotarlos de sentido.

b- Función psicológica: de alguna manera "legitimar" al gobierno militar, a través de los TNC, como ya lo dijimos, utiliza como soporte la violencia y el caos generado por los guerrilleros; pero, sin embargo, la violencia que cometieron los militares contra "inocentes" -porque la violencia extrema hacia personas de izquierda es justificada, por "andar en cosas raras"-, no es defendida por los entrevistados y se recurre, entonces, a la frase "yo no sabía nada". Algunos autores, como Pilar Calviero (1998), sostienen que es imposible no haberse enterado o al menos sospechado de lo que sucedía. Sin embargo, "olvidar" o "no haber visto" ciertas dimensiones que tomó el período, podría circunscribirse a manipulaciones de la memoria colectiva a fin de subsanar la culpa social por "no haber dicho ni hecho nada", más allá de que hubiera sido imposible, porque, como sostienen un gran número de entrevistados, los militares actuaban en contra de "cualquiera que se opusiera a ellos".

c- Función formal: si bien los tres acontecimientos señalados que eligen los narradores para hablar de las causas de la toma del poder por parte de los militares, sucedieron en años diferentes y antes de 1976, son recordados como parte de un mismo período, las fechas se confunden y hasta los episodios. Muchos entrevistados señalaron que cuando Perón arribó a Ezeiza echó a los montoneros del acto y los llamó “imberbes”; sin embargo, este hecho había sucedido un año antes. Pero, claro está, lo que aquí importa no son las fechas exactas, sino el corrimiento temporal de los eventos a fin de utilizarlos como sostenimiento de las expresiones. 


\section{Los Testimonios No Condenatorios y las narrativas coincidentes con los diarios correntinos de la década del setenta}

Los Testimonios No Condenatorios presentes en las entrevistas se hallan compuestos de imaginarios sociales que, en muchos casos, aparecen en la prensa escrita de Corrientes Capital en los años setenta. Podemos realizar una lista de las palabras más reiteradas en las entrevistas, que, coincidentemente, son las mismas que se utilizaban en aquellos años del periodo militar en los diarios correntinos, estas palabras son: "caos", "subversivos", "terroristas", "seguridad", “orden", "atentados", entre otras.

En los años setenta los medios de comunicación masivos más importantes en la provincia eran la radio y los diarios. Entre los diarios de más ventas en la ciudad correntina se hallan El Litoral y diario Época. Se analizaron notas periodísticas correspondientes a los años 1974, 1975 y 1976.

Si bien comprendemos que no es posible describir cómo fue exactamente la recepción de esas narrativas que circulaban en los medios de comunicación por parte de los ciudadanos correntinos en la década del setenta, porque sus imaginarios sociales colectivos fueron indagados en estos últimos años (desde el año 2012 hasta fines del año 2015), consideramos que las cuestiones culturales se caracterizan por ser duraderas en el tiempo y que conforman "marcos interpretativos" generales, tal y como los sostenía Halbwachs, Maurice (2011).

Pensar en sus representaciones, las creadas por medios de formación pública como las que consideramos se hallan en un ámbito más profundo como lo es la cultura, es intentar dar con explicaciones acerca de dónde reside o sustenta su capacidad para sostener testimonios no condenatorios hacia el período militar y, hasta en algunos casos, pedir por su regreso al poder.

En tanto el análisis de diarios, contamos con la investigación precedente de Marina Franco (2012), quien señala, a modo de ejemplo, que los diarios nacionales de mayor tirada, como Clarín, La Nación, La Opinión y La Razón "crearon las representaciones sobre la violencia y la represión como único medio para eliminarla". Franco explica que la lectura sistemática de estos diarios, correspondientes al período 1973-1976, "permite ofrecer una imagen de la producción de representaciones públicas sobre la violencia en los grandes ámbitos urbanos, fundamentalmente porteños y bonaerenses" y que "esta perspectiva asume que la dimensión discursiva es una forma 
de acceder al orden simbólico y al universo imaginario que, dentro de ciertas relaciones sociales, explican la acción política".

A continuación, nos abocaremos a realizar una descripción de aquellos imaginarios sociales de los entrevistados y de las entrevistadas que coinciden con las expresiones utilizadas en los diarios correntinos analizados: El Litoral y Época. Utilizaremos tres de las dimensiones de análisis trabajadas en esta investigación para organizar la información; es decir: Las narrativas de lo sucedido, los Ideales de ciudadano y los Ideales de gobierno.

Narrativas de lo sucedido: cuáles son consideradas las causas de la asunción de los militares en 1976

En este capítulo analizaremos de modo comparativo las expresiones sobre las causas de la toma del poder por parte de los militares en 1976 y las expresiones acerca de "qué sucedía" en el país. Estas expresiones serán tomadas de las entrevistas realizadas, pero, sobre todo, de los diarios correntinos de más tirada de la Ciudad de Corrientes, diarios: El Litoral y Época.

En cuanto a cuáles son consideradas las causas de la toma del poder por parte de los militares en 1976 y la legitimidad de este hecho, tanto en las entrevistas como en los diarios correntinos se menciona que el clima que se vivía en Argentina era "caótico" a causa del accionar violento y delictivo de los subversivos-terroristas, de los cuales únicamente se mencionaban sus ataques y jamás sus ideales ni su voz. Las organizaciones armadas de izquierda son denominadas como apátridas y representantes de intereses extranjeros. Veamos notas periodísticas que circulaban en 1976 donde predominan estas nociones:

Córdoba: Fuerzas de seguridad abatieron a 8 extremistas. (...) se detectó por informes de los pobladores de la zona, un campamento de delincuentes subversivos en la zona de Tres Cascada (...) “Al ser cercado el grupo extremista e intimársele su rendición por las fuerzas legales, los delincuentes subversivos abrieron fuego originándose un intenso tiroteo cuyo resultado fue la muerte de los ocho delincuentes. ${ }^{11}$

${ }^{11}$ El Litoral, 2 de junio de 1976. 
(...) en Córdoba, el general Benjamín Menéndez afirmaba que "estamos nuevamente en lucha contra la subversión, la traición y el enemigo de la Patria" porque "sufrimos una agresión no solo de afuera sino también de otros que nacieron acá pero no son argentinos", el Poder Ejecutivo promulgaba varios decretos disponiendo drásticas medidas en un evidente intento de detener el auge del terrorismo. ${ }^{12}$

El gobierno argentino lamenta profundamente informar que efectivos de la policía de la provincia de Buenos Aires hallaron el cadáver del ex presidente de Bolivia, general Juan José Torres (...) Este nuevo atentado terrorista que alcanza al ex mandatario de un país hermano pone una vez más en manifiesto la sistemática campaña, enunciada ayer por el Ministerio del Interior, para desprestigiar no solo al gobierno de la Nación sino al país todo con el malsano fin de entorpecer nuestro proceso de reorganización nacional. ${ }^{13}$

Asesinan a un coronel. Buenos Aires. Un coronel del ejército fue asesinado esta mañana por un grupo de delincuentes subversivos que aparentemente intentaban secuestrarlo, en tanto que otro oficial de la misma graduación logró dar muerte a un terrorista en un episodio en el cual resultó herida la esposa del militar (...). ${ }^{14}$

No obstante, todos estos acontecimientos y narrativas existieron mucho antes a 1976, motivo por el cual, como lo señala Franco (2012), el golpe recibió el apoyo de muchas/os ciudadanas/os. Veamos, a modo de ejemplo, notas periodísticas anteriores a 1976, puntualmente de los años 1974 y 1975:

Otra acción guerrillera. Buenos Aires. Un grupo integrado por cinco presuntos extremistas redujo hoy a los dos agentes que prestaban servicio de guardia en un destacamento policial (...), se apropió de su armamento e incendió un ómnibus (...). ${ }^{15}$

Córdoba: un ataque de gran envergadura se perpetró contra la casa de gobierno. El estallido de dos de las veinticuatro granadas preparadas y diversas ráfagas de ametralladoras contra

\footnotetext{
${ }^{12}$ El Litoral, 5 de junio de 1976.

${ }^{13} \mathrm{El}$ Litoral, 4 de junio de 1976.

${ }^{14}$ El Litoral, 16 de junio de 1976.

${ }^{15}$ El Litoral, 1 de junio de 1974.
} 
personal de la guardia, descubrieron antenoche un plan terrorista ejecutado contra los edificios de la casa de gobierno (...). El brigadier Lacabanne (...) confirmó el hecho a través de un mensaje a la población (...) "vamos a cumplir la consigna del pueblo, expresó entre otros conceptos, vamos a rescatar la Patria, nuestras instituciones nuestras familias, todo nuestro ser nacional tiene que ser defendido sin palabras, pero sí con hechos positivos para erradicar definitivamente la insurrección y la violencia $(\ldots) .{ }^{16}$

General Acuña: "Tarde o temprano exterminaremos a los extremistas". El general Acuña calificó a los ideólogos del terrorismo como "agentes internacionales que buscan llevar a la Argentina al caos para someterla a una esclavitud colectivista. Desprecian los símbolos nacionales y desprestigian nuestros próceres, la patria, sus instituciones $(\ldots) .{ }^{17}$

En conclusión, los resultados de esta dimensión de análisis se basan en la premisa que el gobierno militar asume a causa del caos que existía durante el gobierno de Isabel. El caos, se dice, provenía de la existencia y accionar de los grupos subversivos "violentos, apátridas e irracionales" que obligaron a los militares -victimas, patriotas y racionales- a responder mediante las armas, lo cual era la única salida al caos.

No obstante, antes de 1976, desde 1973 hasta 1976, en Argentina se desenvolverá un grupo parapolicial de extrema-derecha, denominado "Triple A"-Alianza Anticomunista Argentina-, que actuará clandestinamente y de manera ilegal asesinando a intelectuales, políticos, artistas, sindicalistas y estudiantes de izquierda, entre otros. En los diarios correntinos existen notas acerca de ataques a militantes o simpatizantes de izquierda, no obstante, en la memoria de los entrevistados y entrevistadas la "Triple A" será mencionada, pero de manera muy ligera y en un numero poco significativo de las entrevistas. Es decir, los asesinatos que se recuerdan como antecedente y causa de la toma del poder por parte de los militares en 1976, son los asesinatos perpetrados por la izquierda revolucionaria. Veamos casos noticias en los diarios correntinos que versan acerca de militantes de izquierda, atacadas y asesinadas:

Se combatirá la ola de violencia. Buenos Aires. El ministro del Interior, Benito Llambi, afirmó hoy que el gobierno adoptará "todas las medidas necesarias" para asegurar la paz

${ }^{16}$ Época, 18 de mayo de 1975.

${ }^{17}$ Época, 4 de diciembre de 1975. 
interior en el país como consecuencia de la reiteración de hechos de violencia en la república. (...) durante las deliberaciones se evaluaron los últimos acontecimientos de violencia, en especial los crímenes de militantes de partidos políticos, la ola de atentados y la proliferación de secuestros. El ministro dijo que estos hechos "son provocaciones no solamente de elementos internos" sino que también participan en los mismo "agentes provenientes del exterior" (...). Agregó finalmente el ministro que "se realizaran las investigaciones para esclarecer el asesinato de los tres dirigentes del Partido Socialista de los Trabajadores y de un militante comunista" (...). ${ }^{18}$

La universidad y los golpistas. La conducción del Movimiento Orientación Reformistas (M.O.R) y las agrupaciones reformistas de la U.N.N.E (Universidad Nacional del Nordeste), dieron a publicidad una declaración en la cual se refieren "a la última serie de atentados contra organizaciones y militantes populares". Dice que tales atentados llevan "el inconfundible sello de las bandas fascistas. El terrorismo, expresan, beneficia solo a la ultraderecha. Crean un clima de zozobra, inseguridad, que son el caldo de cultivo para el golpe de estado (...) con el apoyo de la CIA y sus aliados en nuestro país, la oligarquía y los sectores pro-imperialistas (...). Pero, agrega, es posible cerrar el paso a los golpistas". En este último sentido acotan que "en la universidad argentina se están sentando las bases de una nueva universidad acorde con las exigencias de la lucha por la liberación nacional y social (...)". ${ }^{19}$

Extremismo. Diversas noticias relacionadas con las actividades extremistas y antiextremistas fueron dadas a conocer ayer: se identificó como (...) operario de una fábrica de Villa Constitución, el cadáver que el jueves pasado se halló carbonizado en el baúl de un automóvil (...). /En Salta la policía provincial efectuó un operativo anti-extremista que culminó con la detención de cuatro presuntos sediciosos (...). /Una bomba de gran poder estalló en la concesionaria de automóviles de José Jacinto Cesarino, en Lanus (...). /Dos jóvenes hermanos (...) desaparecieron de su hogar en (...) Mendoza (...). ${ }^{20}$

${ }^{18}$ El Litoral, 5 de junio de 1974.

${ }^{19}$ El Litoral, 3 de mayo de 1974.

20 Época, 4 de mayo de 1975. 
Ideales de ciudadano

De las entrevistas realizadas pudimos definir una categoría que resumiría todas las características que conciernen al ideal de ciudadano, dicha categoría la denominamos: "la cultura de la decencia", y se refiere a cumplir con un rol de ciudadano moralmente correcto y "normal", que no cuestiona la autoridad, forma una familia, trabaja y se esfuerza, sin "meterse" en política -ni en la escuela ni en la facultad ni en el trabajo-, no ocupar el tiempo en nada que lo aleje de esos objetivos individuales y "normales". Resulta llamativo como todo lo contrario al "ciudadano decente", para un gran número de los entrevistados, eran los "jóvenes universitarios". Leyendo las notas periodísticas de los años setenta pudo observarse la construcción de este grupo social, "no decente", "subversivo", "criminal". Veamos ejemplos de publicaciones de los diarios correntinos en los cuales se describe "al enemigo" a combatir:

Entre dos líneas: la del orden y la del desorden. En el país se advierten actualmente dos líneas bien definidas: la del orden y la del desorden. En el primero están aquellos que aspiran, con absoluta sinceridad, al progreso, al bienestar, a la paz, a la cordial convivencia entre los argentinos, al desarrollo de nuestro país y a la felicidad de su pueblo. Por el otro campo se ubican quienes tienen por definida meta crear el encono, el caos y la confusión para trastocar nuestro tradicional sistema de vida (...). Se llega incluso a comprometer la paz social, porque de la pugna surge la indisciplina generalizada, al mismo tiempo que se alteran normas de convivencia. ${ }^{21}$

El hecho de acabar con los guerrilleros actuales, aun exterminándolos, solo solucionaría el problema momentáneamente ya que, así como nuestro ejército surgió de los ideales de mayo, la guerrilla tiene su origen en los preceptos marxistas-leninistas acuñados durante años en nuestros estudiantes universitarios. La guerra revolucionaria comienza en las universidades. $^{22}$

${ }^{21}$ Época, 4 de diciembre de 1975.

${ }^{22}$ El Litoral, 5 de noviembre de 1974. 
Paralelamente, se llama a la ciudadanía a "estar atentos para poder brindar información a las fuerzas del orden sobre actividad subversiva" y a evitar que sus hijos caigan en manos de estos “delincuentes". A los periodistas también se los invoca, pidiéndoles "patriotismo a la hora de brindar información". En otros términos, se solicita "moralidad y patriotismo" a todos los ciudadanos, cooperando con las Fuerzas Armadas en el poder. Veamos ejemplos de notas periodísticas:

General Acuña: “Tarde o temprano exterminaremos a los extremistas”. El director de la escuela Superior Técnica del Ejército, General de Brigada Arturo Acuña, declaró que los agentes del terrorismo "se dicen masas explotada y sin derechos, pero entre sus dirigentes no hay obreros ni genuinos representantes del pueblo. Entre ellos solo hay individuos de ambientes de gran consumo, familiares de aprovechadores, que ante el hartazgo de la vida cómoda y sin motivaciones, han encontrado en la subversión un escape a su resentimiento producto de un ambiente materialista que desprecian, pero que en lugar de atacarlo lo encubren, condenando en su lugar a servidores del Estado, Fuerzas Armadas y de seguridad por males y desastres que existen en el medio en el que han vivido.

No hubo novedades en torno al atentado criminal del que fuera víctima el inspector mayor Martínez, de la policía provincial (Corrientes). Como se recordará, dicho funcionario policial fue atacado sorpresivamente con armas largas, por tres individuos quienes viajaban en una camioneta, quienes le hicieron fuego y lograron herirlo. Cuando los terroristas se disponían a intentar rematar su acción fueron contraatacados por la policía (...). En un comunicado aparecido en el baño de la facultad de medicina de esta capital, se adjudica la autoría del episodio a la organización Montoneros (...). Comunicado policial: se cita a toda persona que de una u otra forma pudiera aportar cualquier información que se relacione con el vandálico hecho $(\ldots) .^{23}$

Reflexiones sobre la guerrilla. La guerra revolucionaria comienza en las universidades y el hecho de acabar con el brazo armado no significa que deje de funcionar el cerebro. Lo que

${ }^{23}$ Época, 4 de diciembre de 1975. 
hay que acabar, es la educación extranjerizante que se da a los futuros intelectuales de la nación. La subversión comenzó y debe ser terminada en nuestros centros de estudio. ${ }^{24}$

Para hostigar al gobierno se movilizan grupos estudiantiles Córdoba -no se descarta que en los próximos días se inicie en todo el país movilizaciones de grupos universitarios con fines de hostigar al gobierno nacional. El motivo aparente a ser presentado como justificación será la "disconformidad" con la orientación del ministro de cultura y educación de la nación, doctor Oscar Ivanissevich (...). Se conjetura que cada acción tendrá su inmediata respuesta. Quienes promoverían la agitación serían los sectores calificados como de "ultra izquierdistas". ${ }^{25}$

Como consecuencia del incidente producido la noche del viernes último en el comedor universitario de esta capital, que se inició al término de un discurso en el que se criticaba una medida del rectorado, (...) el presidente de las Agrupaciones Universitarias de Izquierda (FAUDI), Julio Kaplán, permanece detenido en la Gendarmería. ${ }^{26}$

Estudiantes presos. Buenos Aires. Los 22 estudiantes universitarios detenidos (...) fueron pasados ayer a la cárcel de Villa Devoto (...). Dieciocho de ellos pertenecen al Partido Comunista (...). Los restantes pertenecen a la Federación Argentina Universitaria de Izquierda (FAUDI) (...). ${ }^{27}$

Pautas de moralidad. Las faltas de disciplina en ámbitos estudiantiles. Hace pocos días $E l$ Litoral publicó con amplitud las normas impuestas por las autoridades educacionales para mantener la disciplina en los establecimientos de enseñanza secundaria. En esas pautas generales no se ha dejado de contemplar ninguno de los aspectos que hacen a la vida del estudiante (...) en este mismo sentido se ha expedido la Universidad de Buenos Aires (...) de acuerdo con la gravedad de la faltase decidirá las sanciones que corresponden: realizar en la universidad actividades que asumen normas de adoctrinamiento; propaganda; proselitismo o agitación con carácter político o gremial, incursión fuera del ámbito de la universidad en actos que denoten peligrosidad actual o potencial para la seguridad nacional.

\footnotetext{
${ }^{24}$ El Litoral, 12 de noviembre de 1974.

${ }^{25}$ El Litoral 5/11/74

${ }^{26}$ El Litoral, 28 de octubre de 1974.

27 Época, 13 de mayo de 1975.
} 
En los casos de que los alumnos tengan reiteradas faltas se podrá determinar su expulsión de cualquier casa de estudio, ya sea nacional o provincial. ${ }^{28}$

Inminente definición sobre universidades. El gobierno nacional procederá (...) a designar rectores para las universidades de todo el país (...) trascendió que (...) se desea evitar toda repetición de errores que afectaron seriamente los institutos de educación superior en todo el pasado reciente. Según esos círculos debe descartarse la universidad "militante", que intentó convertirse, a través de una extrema politización, en la vanguardia de un proceso no compartido por las mayorías populares (...). ${ }^{29}$

La 3ra Brigada informó sobre varias acciones. Los propósitos que persigue el ejército en su lucha contra la subversión fueron ampliamente explicitados por el Coronel Rafael Zabala Carbó. (...) "desgraciadamente estamos en guerra -dijo- y esto en la población que no está con las armas supone sufrimiento". "Para lograr la victoria -agregó- se debe contar con el apoyo de la población. Esta lucha tiene carácter decisivo para la patria. Si fracasamos -sentenció- solo Dios sabrá lo que nos puede esperar". Misión de la prensa: seguidamente se explayó sobre el papel que puede y debe cumplir la prensa. A su entender la colaboración que puede prestar se resumiría omitiendo dar publicidad favorable a la acción subversiva. Además, se debe tener cuidado en las editoriales y notas de fondo, mientras por otra parte se debe hacer comprender a la población el sentido de esta lucha. ${ }^{30}$

Todo lo contrario, a los llamados "ciudadanos decentes", en las entrevistas y en los diarios correntinos, eran las personas pertenecientes a la izquierda revolucionaria, los cuales serán caracterizados como jóvenes de la clase media y alta, holgazanes, resentidos, dedicados de lleno a luchar y no en estudiar, trabajar y formar una familia. Jóvenes que "no iban a la facultad a estudiar" y que no son nacionalistas, sino defensores de ideologías extranjeras.

Ideales de gobierno

¿Cuáles son los sentidos construidos en aquel entonces que persisten hoy? En las entrevistas realizadas que reflejan TNC, se pudo observar un discurso claramente antidemocrático, valorando

\footnotetext{
${ }^{28}$ El Litoral, 3 de junio de 1976.

${ }^{29}$ El Litoral, 14 de junio de 1976.

${ }^{30}$ El Litoral, 20 de noviembre de 1975.
} 
el régimen militar en contrapartida al democrático. La democracia es considerada como corrupta, libertina, inepta e ineficaz para detener la delincuencia y los crímenes; entendiendo de manera opuesta al gobierno militar, es decir, como "garante del orden y la seguridad". Cabe destacar que el tipo de democracia al cual se hacía mención en las entrevistas era al correspondiente al gobierno de Isabel Perón, pero, sobre todo, al de Cristina Kirchner, también peronista.

En los diarios correntinos de los años setenta, podemos observar una comparación entre el régimen militar contrapuesto al gobierno peronista o al posible "gobierno comunista". En ambos casos, en los diarios como en las entrevistas, las caracterizaciones del gobierno militar asumen las definiciones de "garantes del orden y la seguridad", actuando "como se debe" ante los "delincuentes"; en otros términos, por supuesto, no se presentaba a la represión como tal y esta representación es la que subsiste en las personas entrevistadas. Observemos ejemplos de los diarios:

Ejemplo de cuando la ingenuidad es un pecado. Reflexión sobre los derechos humanos. Frente a la realidad política nacional y mundial se pueden asumir distintas actitudes (...) o único que no cabe en tanta y tan libérrima perspectiva es ser ingenuo. (...) todos los países que hoy se encuentran bajo la férula soviética, incluso en nuestro continente, carecen de opción ideológica (...) y a ello se llegó, entre otras razones, por la ingenuidad de quienes se dejaron seducir, en su momento, por la política comunista. Los comunistas (...) impulsan reclamos y campañas en favor de libertades y derechos que, una vez legados al poder, abrogan de cuajo. (...) y bien, los que ostentan el signo de los grandes genocidios del siglo (y acaso, de la historia) (...) se erigen hoy una vez más en los campeones de los derechos humanos. ${ }^{31}$

Ratificó Massera los objetivos políticos del gobierno militar: "la meta a alcanzar es una democracia basada en la eficiencia, en la libertad con responsabilidad, en la justicia y en la convivencia social", afirmó hoy el comandante general de la armada, almirante Emilio Eduardo Massera, al ofrecer un agasajo a los representantes de la prensa con motivo del día del periodista. (...). "La armada a lo largo de su trayectoria profesional e institucional, ha sido baluarte de las libertades y derechos del hombre (...) es también por eso que la

\footnotetext{
${ }^{31}$ El Litoral, 14 de junio de 1976.
} 
armada, en toda su historia, no ha comulgado con ninguna de aquellas ideas extremistas, cualquiera sea su signo que irracionalmente, grupos ideológicos tratan de insertar en nuestra juventud (...) esto no es nuevo para nosotros, nos apoyamos en las líneas directrices que Mariano Moreno en los días iniciales de la patria trazó (...) No tengo duda, finalizó el almirante Massera, basado en mis contactos de varios años con el periodismo, que sabrán asumir con dignidad la ímproba tarea que el país requiere de sus hombres de prensa y que respetando las libertades de opinión darán un claro ejemplo de patriotismo (...)".32

Inician un nuevo proceso judicial a la ex presidente de la república. La señora María Estela Martínez de Perón y varios de sus colaboradores inmediatos durante su actuación pública, serán sometidos a un nuevo proceso judicial, esta vez referido al manejo irregular de los fondos reservados de la Presidencia de la Nación. ${ }^{33}$

Si pensamos en la cultura conservadora de la provincia de Corrientes, esta tiene especial concordancia con la ideología del régimen militar. "Dios, patria y familia" serán invocados por los militares en la década del setenta y también en la cultura de la decencia correntina, palabras que aun hoy resuenan en los discursos escuchados en las entrevistas. A continuación, citaremos una nota periodística a modo de ejemplificación:

“En todos los discursos campeó una definición. Condena y repudio para la subversión. El repudio que provocó el brutal asesinato del general Cardozo tuvo notable repercusión en todas las alocuciones que se pronunciaron con motivo del día de la bandera. Términos de enérgica condena y de reafirmación del propósito de seguir hasta el final la lucha contra los elementos de la subversión, fueron el común denominador de todos los discursos. La consigna de "morir si fuera necesario en esta lucha que libra el pueblo" (como afirmara el general Nicolaides (...)) fue una expresión que marcó el tono de los más altos jefes militares (...). En la ceremonia realizada en Rosario, al pie del monumento a la bandera (donde asistió el presidente Videla) la alocución estuvo a cargo del Segundo comandante del Cuerpo $\mathrm{II}^{\circ}$ del Ejército, General Andrés A. Ferrero. "Al pie del monumento a la bandera -- "En estos momentos especiales -expresó el Alto Jefe Militar- que vive la República, en los cuales se quiere destruir los principios básicos de la nacionalidad, en los que se pretende

\footnotetext{
32 El Litoral, 10 de junio de 1976.

${ }^{33}$ El Litoral, 16 de junio de 1976.
} 
masificar al ser argentino, en los que se quiere destruir la sociedad, la familia y la moral con el empleo de una subversión apátrida, malsana, ruin, destructora y productora de odios, es en esos momentos en que no puede concebirse que ningún individuo por más insignificante que parezca, pueda, de ser necesario y verdadero contingente para evitar que eso suceda (...)". Más adelante, el general Ferrero afirmó: "este juramento significa que prometéis ofrendar vuestra vida en defensa de la nación, de su estilo, de su filosofía y de su religión para que pueda proyectarse hacia el futuro sin que ninguna ideología, cualquiera sea el nombre que ella lleve, pueda quebrar su proyección histórica y así, teniendo objetivos claros y precisos, podamos seguir construyendo esta patria grande que es la Argentina, que deseamos para nuestros hijos y los hijos de nuestros hijos” (...). En Bahía blanca se realizó la ceremonia de entrega de espadas a oficiales y suboficiales de la Marina de Guerra. En esa oportunidad habló el comandante de operaciones navales, Vice Almirante Luis M. Mendia, quien expresó: "se os entregan benditas (espadas) para que no olvidéis que el Señor está siempre de vuestro lado para premiar los aciertos y juzgar los errores. Se os entrega frente al pabellón de la Patria para que tengáis presente que nadie puede arriarlo jamás por la fuerza, que vosotros, al aceptar este símbolo de mando, adquirís el solemne compromiso de evitar, aun a costa de la vida, que los mercaderes del odio no puedan mancharlo con otro rojo que no sea el de vuestra sangre". 34

Concluyendo, podemos establecer que estas maneras de "relatar" los hechos y acontecimientos, por parte de los diarios correntinos, tienen coincidencias con la información adquirida de manera empírica a través de las entrevistas, puesto que los grupos sociales no universitarios dijeron desconocer los objetivos de la izquierda revolucionaria, sus propuestas y sus planteos; al mismo tiempo, tanto universitarios como no universitarios, mencionan a las organizaciones de la izquierda revolucionaria como "delincuentes" y "terroristas", se justifica el accionar violento de las fuerzas armadas y policiales y se plantea que la única salida al "caos" que vivía la Argentina durante el gobierno de Isabel solo podría haber sido resuelto mediante la fuerza y no mediante la democracia.

No obstante, si bien en este trabajo partiremos de la misma premisa de la autora Marina Franco (2012), cuando señala que los medios de comunicación influyen en la circulación de imaginarios sociales que son utilizados políticamente, proponemos pensar también en los valores culturales

\footnotetext{
${ }^{34}$ El Litoral, 21 de junio de 1976.
} 
que van de la mano de ciertos planteos políticos. Lo que aquí denominamos "cultura de la decencia" se refiere a esos imaginarios sociales que destacan al rol de ciudadano que no cuestiona la autoridad, forma una familia, trabaja y se esfuerza, sin "meterse" en política ni en nada que lo aleje de esos objetivos individuales y "normales". Desde esta perspectiva -de la decencia- se puede crear una imagen de "enemigo" contrapuesta a estos ideales. Algo similar ya menciona Franco (2012), cuando describía la cultura política argentina: "la lógica amigo-enemigo, la generación de enemigos internos, el pensamiento conspirativo, el anticomunismo, la definición de la pertenencia nacionalista escencializada, el espíritu unanimista que pretende encarnar la totalidad de la voluntad política, forma parte de la cultura política argentina".

Las narrativas de los diarios en la década de los setenta

Marina Franco (2012) estudió los discursos políticos y periodísticos porteños dominantes en el período que se extendió entre 1973 y 1976 y su imbricación con el clima favorable que existió hacia la toma del poder por parte de los militares en 1976, cuando la violencia se había naturalizado. Tras la lectura de esta obra podemos plasmar una lista con expresiones utilizadas en los diarios de Capital federal y de la Provincia de Buenos Aires que coinciden con expresiones utilizadas en los diarios correntinos Época y El Litoral, analizados en este trabajo. La lista de expresiones recurrentes para "informar" de lo que sucedía podría sintetizarse de la siguiente manera:

1. "El discurso subversivo-antisubversivo fue utilizado (...) para transformar a las Fuerzas Armadas en víctimas de la subversión y en la única salida al caos". Se expresa una interpretación de la realidad como un caos generalizado a causa de subversivos antipatrióticos y violentos. Planteando a las fuerzas armadas como las únicas idóneas para

2. "La violencia, el extremismo y el terrorismo pudieron ser de derecha y de izquierda, (pero) la noción de lo subversivo solo fue aplicada al universo de la izquierda".

3. "La convicción sobre la necesidad de la lucha antisubversiva hizo llamados a la colaboración civil. Las Fuerzas Militares invocaron reiteradas veces a participar activamente en esa lucha contra los enemigos de la patria”. 
4. "En los medios (...) se evitaba nombrar a los guerrilleros como representantes de ideologías diferentes, sino como meros delincuentes".

En esta misma línea, Federico Lorenz (2007), escribe sobre lo que él denomina la "vulgata procesista", nombre con el cual describe a la memoria subterránea -no oficial en cuanto el gobierno nacional ejercido por los presidentes Néstor Kirchner y Cristina Fernández de Kirchner sostienen un discurso claramente condenatorio acerca del período militar- sobre el período militar, que tuvo puntos de convergencia con las denuncias que los organismos de derechos humanos vienen realizando desde el regreso de la democracia al país en el año 1983. En palabras del autor: esta memoria subterránea "es un relato que justifica la represión ilegal, contraponiéndole la violencia de las organizaciones armadas" Federico Lorenz (2007). Es decir, se resalta la violencia ejercida por las agrupaciones de izquierda, exigiendo que sean condenados quienes la ejercieron del mismo modo como lo fueron integrantes de las Fuerzas Armadas. Dirá Lorenz: "la vulgata procesista es simbólicamente eficaz porque se apoya en claros, ausencias u omisiones de los relatos de sus antagonistas políticos, sobre todo asociados al asesinato político”.

El autor cita como principal referente de la "vulgata procesista" al general de división e historiador militar: Ramón Genaro Díaz Bessone. Besson, quién publicó, en 1986, un libro llamado “Guerra revolucionaria en la Argentina (1959-1978)", una obra reeditada dos veces por el Círculo Militar y que Lorenz analiza para extraer todos los argumentos utilizados para legitimar y reivindicar al gobierno militar. Su relato, dirá Lorenz, construye la historia como una respuesta de las Fuerzas Armadas a la agresión de unas minorías, denominados “enemigos de la Nación Argentina”, contra el conjunto de la sociedad.

Lo novedoso que podemos agregar a esta descripción de la "vulgata procesista" descripta por Lorenz es que quienes sostienen Testimonios No Condenatorios hacia el gobierno militar en la Ciudad de Corrientes, correntinos y correntinas que vivieron el período, resaltan exactamente muchos de los mismos argumentos de Díaz Bessone, sin haber leído ese libro. Piden castigo para los terroristas que mataron a militares y policías y entienden que los militares respondieron a agresiones que iniciaron los subversivos.

Seguidamente, Lorenz hace mención al acontecimiento que es considerado como el "inicio" de la guerra, este hito es el asesinato del general Eugenio Aramburu por parte de la agrupación 
Montoneros en el año 1970. Esta noción, además, caracteriza a los subversivos como irracionales, violentos, dementes. Tanto por parte de los militares como por parte de los medios de comunicación de la época, comienza todo con este asesinato, el cual evidencia perfectamente quienes son los malos y quienes son las víctimas. Esta misma explicación es la que se escucharon en las entrevistas realizadas en esta investigación. Ninguna de las personas entrevistadas, tanto dentro del grupo de los universitarios como en el grupo de los no universitarios, mencionó otro hecho u acontecimiento como el inicio, tales como podría ser el golpe de Estado de 1955, el de 1966, entre otros episodios brutales llevados a cabo por las Fuerzas Armadas, de los que inclusive Aramburu fue actor.

Cabe destacar, por ende, que el rol cumplido por los medios de comunicación masivos quizás haya jugado un rol inconmensurable a la hora de brindar explicaciones a poblaciones como la correntina que "se enteraban de todo a través de la radio y de los diarios", tal como los entrevistados y entrevistadas lo señalaran, y como lo demuestra las enormes coincidencias entre los testimonios recogidos y los relatos presentes en los diarios El Litoral y Época de Corrientes. No obstante, medir cuánto de los TNC fueron moldeados por los medios de comunicación es, por lo menos, muy enrevesado ${ }^{35}$.

\footnotetext{
${ }^{35}$ Entre otras perspectivas encontramos a Feierstein (2018), quien señaló que la teoría de los dos demonios sirvió, entre otras cuestiones, para que un sector de la sociedad, la "gente común" -quienes no tenía relación con ninguno de los dos demonios-, comprendiera que desafiar el orden instituido termina en baños de sangre y que para evitarlo hay que aceptar los límites establecidos por el poder político, y que esta funcionalidad de dicha teoría, sirvió más a su éxito que ninguna conspiración o control del aparato mediático.
} 
Capítulo 6

A modo de cierre: ¿Qué son los Testimonios No Condenatorios?

El recorrido de esta investigación partió desde un interrogante: ¿cuáles son los imaginarios sociales que componen los testimonios no condenatorios -entendidos como memorias colectivas- hacia la última dictadura militar por parte de ciudadanas y ciudadanos que vivieron el período en la Ciudad de Corrientes? 
Cabe destacar que partimos, en el inició de la investigación, con una premisa acerca del tipo de relación que existió entre la sociedad y el gobierno militar: los militares contaron con el apoyo de un gran porcentaje de ciudadanos y ciudadanas, desde el día del golpe de Estado hasta, inclusive, unos años más tarde. Lo que resultaba más difícil de estimar era la dimensión de los Testimonios No Condenatorios hacia el accionar del gobierno militar en la actualidad, sobre todo considerando el gran bagaje de información pública que en estos años democráticos circuló acerca de los delitos de lesa humanidad ejercidos por el mismo. Y si bien es de amplio conocimiento que a lo largo del país existen Testimonios No Condenatorios hacia el gobierno militar, en el presente trabajo nos limitamos a investigar sobre los existentes en una de las ciudades del "interior" del país: la Ciudad de Corrientes, capital provincial.

En pocas palabras podemos describir a los Testimonios No Condenatorios como un conjunto de reivindicaciones y justificaciones al gobierno militar de 1976-83 en Argentina, por parte de ciudadanas y ciudadanos que vivieron el período en la ciudad de Corrientes.

En un porcentaje mayoritario, las personas entrevistadas enfatizaron en que la dictadura no fue vivida como tal por ellas, sino que se trató de una guerra entre dos facciones: los militares y los guerrilleros, que ambos bandos fueron violentos pero que los militares tuvieron un objetivo "necesario": "salvar" a la nación de los guerrilleros terroristas y apátridas, aunque en muchas entrevistas también se mencionó el accionar violento de la Triple A.

El único papel que se le atribuye a la ciudadanía fue el de añorar el golpe militar por la crisis política y económica que se vivía durante el gobierno decadente de Isabel Perón y por el accionar de la guerrilla. Las personas entrevistadas se auto referencian como "quienes no tenían nada que ver" y que, gracias a ello, no vieron afectada su vida cotidiana durante los años de la dictadura. El terrorismo de Estado, para las personas entrevistadas, es asemejado con una "película", señalando con este ejemplo que "en Corrientes no pasaba nada", y que todo lo que saben acerca de ello lo hacen gracias a los medios de comunicación. Cabe destacar que muchas de las personas desaparecidas y asesinadas durante el gobierno militar en Corrientes pertenecieron a las ligas agrarias de la ciudad de Goya, ciudad situada aproximadamente a unos 226 kilómetros de la Ciudad de Corrientes. Las ligas agrarias fueron un movimiento de campesinas/os y trabajadores rurales que estaban organizados de la mano de los "curas tercermundistas" (teología de la Liberación) y reclamaban ante los latifundistas y empresas tabacaleras (entre otras) cuestiones tales como 
mejoras laborales, reparto de la tierra, entre otras cuestiones. Lo notable es que las personas entrevistadas cuyo nivel económico era bajo expresaron desconocer por completo la existencia de las ligas agrarias, mientras que las personas entrevistadas con mayores recursos sí tenían conocimientos al respecto de las mismas. Ver aca las formas en que lo justifican las personas, capaz un rico no decía que vuelvan los militares pero de manera mas solapada o fina decían algo peor.

Una característica fundamental de muchos de los TNC consiste en su empeño por desconocer a los derechos humanos como un bien cultural. Los TNC se edifican sobre la comparación entre el pasado y el presente con respecto a la "seguridad" que poseían/poseen "las/os ciudadanas/os decentes" ante la "delincuencia" -por supuesto, equiparando guerrilla de los años setenta con delincuencia actual-. Ante esta constatación, el presente sale perdiendo en cuanto los militares "tenían mano dura" para los malvivientes, mientras que "los gobiernos democráticos actuales y los derechos humanos los protegen". La izquierda revolucionaria es asemejada con la delincuencia y sus proyectos políticos o son desconocidos o son subestimados en el menor de los casos. Este es un claro ejemplo, de cómo los TNC están formados de justificaciones que se utilizan para reivindicar, explícitamente o implícitamente, a la dictadura militar.

Otra característica llamativa de los TNC consiste en las importantes coincidencias que pudimos encontrar al comparar muchos de los imaginarios sociales presentes en las entrevistas con la forma en que era presentada la información por los diarios correntinos de mayor tirada de los años setenta en la ciudad correntina -recordemos que este era el medio masivo de información predominante en cuanto no era común hasta ese momento el uso de televisores-. Las coincidencias tienen que ver con cuestiones tales como las que se denominan las causas del golpe de Estado de 1976: "el gobierno militar asume a causa del caos que existía durante el gobierno de Isabel. El caos, se dice, provenía de la existencia y accionar de los grupos subversivos "violentos, apátridas e irracionales" que obligaron a los militares -victimas, patriotas y racionales- a responder mediante las armas, lo cual era la única salida al caos." Asimismo, a lo largo de las notas, se destacan cuáles deben ser los valores éticos "apropiados" de la ciudadanía, los cuales se hallaban relacionados con "Dios, la patria y la familia", resaltando como modelo de ciudadano moralmente correcto y "normal", aquel que no cuestiona la autoridad, forma una familia, trabaja y se esfuerza, sin "meterse" en política en la escuela ni en la facultad ni en el trabajo. En los diarios correntinos de los años setenta, 
además, podemos observar una comparación entre el régimen militar en contraposición al gobierno peronista o el posible gobierno "comunista". En ambos casos, en los diarios como en las entrevistas, las caracterizaciones del gobierno militar asumen las definiciones de "garantes del orden y la seguridad", actuando "como se debe" ante los "delincuentes"; en otros términos, por supuesto, no se presentaba a la represión como tal y este imaginario es el que subsiste en las personas entrevistadas. Paralelamente a ello, todas las referencias que se hacen en los diarios acerca de la izquierda revolucionaria solo involucran cuestiones de violencia -entre otras críticas, sin explicar cuáles eran sus motivaciones, proyectos políticos u objetivos finales; presentándola como seres irracionales motivados por el odio y guiados por países extranjeros.

Los Testimonios No Condenatorios representan a una variante de memoria social y, como tal, está compuesta de imaginarios sociales compartidos. Lo que pudimos observar en esta investigación es que dichos imaginarios sociales se hallan presentes en diferentes clases sociales correntinas, es decir, trascienden, en líneas generales, el nivel de instrucción formal y el tipo de ocupación o profesión, más allá de que las maneras de expresar las opiniones, los recuerdos, los conocimientos varíen, existen líneas transversales.

Los Testimonios No Condenatorios presentan diferentes intensidades, aquí distinguimos dos para dar a conocer nuestros resultados: los Testimonios No Condenatorios de "reivindicación explícita", los cuales expresan el deseo irrenunciable de que vuelvan los militares al poder político y, por otro lado, los Testimonios No Condenatorios de "reivindicación implícita", los cuales reivindican el período militar y critican fuertemente la democracia, pero no reclaman que los militares deberían volver a gobernar, mencionan, a modo de ejemplo, cuestiones tales como el deseo de "un gobierno ideal en el cual los militares integren el gobierno democrático pero únicamente para hacerse cargo de la seguridad".

Enfocándonos en los resultados de las entrevistas pertenecientes al grupo de los Testimonios No Condenatorios hacia el período militar de 1976-83, sin hacer distinción entre TNC de "reivindicación explícita" y TNC de "reivindicación implícita", por parte de las correntinas y correntinos que vivieron el período, podemos establecer cuatro diferentes dimensiones de análisis, describiendo cuales son los imaginarios sociales que componen dicha memoria social. Estas representaciones sociales consisten en: narrativas de lo sucedido, ideales de ciudadano, ideales de gobierno y experiencias personales. 
Esta dimensión de análisis hace referencia a los conocimientos sobre las causas de la toma del poder por parte de los militares en 1976 y explicaciones acerca de qué sucedía en el país. Esta dimensión se relaciona con el tipo de información que se posee sobre el período militar académica, reflexiva, irreflexiva, inexistente, confusa, extensa, limitada, etc.- y con el rol de los medios de comunicación, indagando en las fuentes de información que las personas entrevistadas utilizaron y utilizan. Estas narrativas presentes en los TNC están conformadas por:

Justificaciones hacia la toma del poder por parte de los militares mediante un golpe de Estado en 1976, justificaciones en cuanto se señala al período de Isabel como caótico y se valora positivamente el rol de los militares en cuanto "se debía" terminar con los grupos subversivos de "ideas extranjeras" que "mataban, ponían bombas y secuestraban" para "tomar el poder en Argentina".

Desconocimiento, por parte de personas no universitarias, de los proyectos de país que se disputan en los setenta. Especial desconocimiento acerca de ideologías de izquierda.

El caos se debía a los grupos subversivos violentos, apátridas e irracionales que obligaron a los militares -victimas, patriotas y racionales- a responder mediante las armas, lo cual era la única salida al caos.

Los ideales de ciudadanos

Esta dimensión de análisis se pregunta por aquellas nociones y opiniones que poseen acerca del rol que debe cumplir un ciudadano, qué es valorado como adecuado/inadecuado, fructífero/intrascendente, normal/anormal, coherente/incoherente, entre otras cuestiones. Valores del trabajo, el hogar, las instituciones, etc. Los ideales ciudadanos presentes en los TNC están conformados por:

La contraposición entre los “ciudadanos decentes" y los “subversivos”. 
La "cultura de la decencia”, creencia según la cual se justifica la detención de personas que no dediquen su vida exclusivamente al trabajo, estudio y a la familia, conformando estas instituciones "lo normal".

Persistencia de la frase "algo harán hecho" para descalificar a quienes hayan sido afectados por los militares en aquel período, porque "los militares sólo perseguían a los que andaban en algo raro", no al "ciudadano decente".

Los ideales de gobierno

Esta dimensión alude a las ideologías (formación doctrinal), percepciones, valores, concepciones e información que poseen acerca del gobierno y su rol, de las jerarquías. También hace referencia a las actitudes políticas, tales como las posturas y las disposiciones - provocativa, reflexiva, pasiva, indiferente, comprometida, etc. ¿Cuál era la lucha? ¿Quiénes eran las víctimas? Cosmovisión que no es adherente a una doctrina específica, sino que tiene raíces en la cultura, en cuanto involucra valores y experiencias personales, además de conocimientos. En los TNC los ideales de gobierno están constituidos por:

$>$ Cuestiones antidemocráticas. Enfoque fijado en cuestiones de seguridad.

Valoraciones negativas hacia la democracia o críticas hacia la misma, en cuanto es relacionada con "inseguridad", "droga", "planes sociales que mantienen a vagos", "jóvenes delincuentes”, “corrupción” y “asesina por medio de la pobreza y la corrupción”. Quienes dijeron apreciar la democracia sostuvieron que, en realidad, "los argentinos no sabemos vivir en democracia ni qué es".

> Valoraciones positivas hacia el gobierno militar, casi exclusivamente por haber evitado en aquellos años la seguridad, entendiéndose a la misma como seguridad ante la delincuencia.

> Comparaciones de la izquierda revolucionaria con delincuentes y terroristas, que de manera justa y legítima fue abatida.

Aceptación explícita de la violencia que ejercieron los militares hacia los "subversivos", es decir, no se legitima la violencia hacia "inocentes", pero los subversivos son 
considerados delincuentes merecedores de lo que les sucedió. Persistencia de la frase "algo habrán hecho".

Ideales de gobierno que se circunscriben a que el mismo debe centrarse en garantizar seguridad, el orden y respeto hacia las autoridades y hacia las personas mayores. Ideales que existían en el pasado y hoy desaparecieron.

$>$ Características conservadoras a la hora de juzgar un gobierno como positivo/negativo. Se valora a la familia/patria/policía/docencia como instituciones que no deben ser violadas, las cuales se respetaban durante el gobierno militar y se desvalorizan durante la democracia.

Experiencias personales de las personas entrevistadas durante el gobierno militar

Esta dimensión indaga en las experiencias vividas durante el periodo militar, las experiencias violencias, si la persona entrevistada posee amigos, familiares y/o conocidos desaparecidas/os, se indaga en la profesión o nivel de instrucción formal, en la pertenencia o no a partidos políticos, en la familia y vida cotidiana. Las experiencias personales en común que poseen las personas con TNC son las siguientes:

La visualización del gobierno militar como un período de paz, en el cual se señala no haber sentido miedo por mantener conductas adecuadas, valoradas como adecuadas no sólo por el régimen sino también por sí mismos. Las y los entrevistados señalan haber vivido un período de seguridad en cuanto a la delincuencia.

La concepción de Corrientes como una provincia donde "no existió" la "dictadura militar", en cuanto se sostiene que "en Corrientes no pasaba nada, porque es muy conservadora". Los hechos sucedieron en las grandes ciudades del país, lo cual era la información que circulaba en los medios de comunicación masivos como la radio y los diarios.

Se señala que no conocieron personas cercanas que hayan desaparecido ni que hayan sido torturadas, tampoco experimentaron atentados ni secuestros de personas. 
Recuerdan haberse enterado de lo que hacían los subversivos a través de los medios de comunicación -radios y diarios, principalmente-, mientras que dicen haberse enterado del accionar militar excesivo luego de 1983, cuando regresó la democracia.

Sostienen que veían a los militares pidiendo documentos en la vía pública, lo cual les parecía y parece correcto.

Recuerdan que "en esa época" había respeto hacia las personas mayores, hacia los maestros/padres/policía, en pocas palabras a la autoridad.

Las coincidencias encontradas entre los entrevistados de diferentes grupos sociales en cuanto a las representaciones sociales que versan acerca de cómo sienten, piensan y vivieron el período del gobierno militar, privilegiando ciertas dimensiones o aspectos del pasado y restando importancia a otras, nos permiten definir a los TNC como un conjunto de reivindicaciones hacia la toma de poder por parte de los militares en 1976 y hacia su gobierno de facto. Una síntesis de los imaginarios sociales presentes en los TNC podría ser la siguiente:

“el gobierno militar fue la única salida válida que existió para eliminar a las organizaciones de guerrilleros que no eran más que delincuentes y asesinos que querían tomar el poder en Argentina, en nombre de ideologías extranjeras, poniendo bombas, secuestrando y matando. Los militares salvaron a la Argentina y lo que hicieron con los guerrilleros es legítimo, sus únicos errores fueron los excesos y haber robado bebes. Durante el gobierno militar la gente decente no tenía problemas, vivía en paz porque había seguridad, orden, existía la cultura del esfuerzo y había respeto hacia las instituciones hacia la autoridad y hacia las personas mayores, solo tenían problemas los que andaban en cosas raras, quienes hayan tenido problemas con las Fuerzas Armadas es porque algo habrá hecho. La democracia, en cambio, significó la aparición de la delincuencia, corrupción, inseguridad, vagancia y planes sociales, drogas y libertinaje. Los derechos humanos solo lograron proteger a los delincuentes mientras los ciudadanos decentes tienen que vivir con miedo. Por estos motivos un nuevo gobierno militar sería necesario, para que los delincuentes y los "planeros" desaparezcan." 
En esta definición lograda de TNC, podemos hallar una clara y contundente vinculación entre el pasado y el presente, porque esa vinculación es la esencia misma de las memorias sociales. En esas memorias sociales convergen tanto la memoria pública, aquella que se transmite a través del poder, como también aspectos culturales. Las y los entrevistados pasaron, en grandes rasgos, por tres memorias oficiales desde los años setenta hasta la actualidad:

> Política estatal de construcción de la memoria durante la década del setenta: exponía la existencia de un demonio: la izquierda revolucionaria.

$>$ Política estatal de construcción de la memoria durante los años de regreso de la democracia: La existencia de dos demonios equiparados: el "terrorismo estatal" y el "terrorismo de izquierda".

> Política estatal de construcción de la memoria durante las presidencias Kirchneristas (20032015): La existencia de un demonio: los militares.

Los TNC continúan reproduciendo la memoria predominante en la década del setenta, en sus representaciones sociales políticas "el enemigo" es la izquierda revolucionaria. La memoria oficial de los años setenta y su presencia en la ciudad correntina, se pudo observar cuando al indagar en los diarios de mayor tirada de los años setenta en la Ciudad de Corrientes, diario El Litoral y diario Época, nos encontramos con muchas de las narrativas presentes en los TNC de nuestros entrevistados y entrevistadas.

Continuar reproduciendo la figura de un demonio, el demonio de la izquierda revolucionaria y legitimar, por ende, el accionar de las fuerzas armadas, será lo que convertirá a los TNC en memorias subterráneas, porque están constituidas por aquellas memorias transmitidas informalmente, de manera simulada u oculta. Las memorias subterráneas se edifican en contraposición casi irreconciliable a las memorias colectivas oficiales, como lo conformas las memorias públicas desplegadas durante los gobiernos Kirchneristas, período en el cual se realizaron las entrevistas.

Asimismo, consideramos que los elementos culturales presentes en los TNC, se pueden observar en las características conservadoras que podemos rastrear en los relatos, tales como "la valoración de la familia/ patria/ policía/ docencia como instituciones que no deben ser violadas, que fueron respetadas en la época de los militares y que son despreciadas hoy." Paralelamente y en vinculación 
con el conservadurismo, el concepto de "cultura de la decencia", categoría creada en el transcurso de la investigación para describir las "formas de ver la realidad" de los entrevistados y entrevistadas, presentan una red cultural de interpretaciones. La cultura de la decencia hace referencia al "deber de los ciudadanos y ciudadanas", el cual consiste en no cuestionar la autoridad, formar una familia, trabajar y esforzarse, sin "meterse" en política ni en nada que los aleje de esos objetivos individuales y "normales". Cabe destacar que, coincidentemente, el acta que establecía los objetivos del proceso de reorganización nacional, señalaba como propósitos básicos establecer "la vigencia de los valores de la moral cristiana, de la tradición nacional y de la dignidad del ser argentino, (...) y la vigencia de la seguridad nacional, erradicando la subversión y las causas que favorecen su existencia".

Estas interpretaciones acerca de los TNC nos permiten, de manera simultánea, replantear un mito surgido con la elaboración de la teoría de los dos demonios en los años recientes del regreso de la democracia y que en las entrevistas también se hicieron presentes: el mito del ciudadano normal, aquel que no tenía nada que ver con los dos demonios y que representaba a la mayoría de la población, la cual, supuestamente, se hallaba ajena e inocente, silenciosa y muchas veces miedosa, que sufría a causa de los acontecimientos violentos y que solo abogaba por la paz y la vida democrática.

Tomar en consideración a los TNC nos coloca frente a un desafío: ver más allá de los relatos o narraciones oficiales, notas las corrientes subterráneas presentes en la ciudadanía. Portelli (2016) señalaba en este mismo sentido que "las memorias relegadas al sótano del olvido vuelven a emerger como fantasmas". Para ilustrar podemos señalar un ejemplo: en el mismo año que Mauricio Macri ganaba las elecciones en 2015, el diario La Nación publicó una editorial que exigía, entre otras cuestiones, avanzar hacia una "memoria o verdad completa", en pocas palabras: que los "guerrilleros también sean juzgados al igual que los militares", tal y como varias de las personas que entrevistamos reclamaban. Estas narrativas nos llevan al concepto de "la teoría de los dos demonios recargada" de la cual habla Feierstein (2018), según la cual, en la actualidad, aun podemos observar un intento por reestablecerla, apartando a la sociedad en su conjunto y hablando de terrorismos equiparados en el nivel de violencia, pero con una diferencia: en la versión original de la teoría de los dos demonios se ponía mayor énfasis en la violencia ejercida por el Estado, en la actualidad, en cambio, se centra en la violencia insurgente, pidiendo justicia para los militares 
asesinados. En relación a lo señalado por Feierstein, podemos mencionar el aval que dio Mauricio Macri, ya en el cargo de presidente -año 2019-, al proyecto de ley que buscaba otorgarles subsidios a familiares de militares asesinados por organizaciones de la izquierda revolucionaria. La democracia denominada como "la mejor forma de gobierno" no es defendida por toda la ciudadanía. Considerar que las dictaduras son cosas del pasado que "nunca más" sucederán es, al menos, dudoso cuando existen sentimientos antidemocráticos arraigados en una sociedad. Esto nos recuerda el concepto de "memoria-monumento" de Portelli (2016), según la cual una placa o estatuas de bronce no pueden esconder todo lo que hay detrás y que no queremos ver. La memoria sirve no solo para condecorar los sucesos que nos resultan más útiles, afables o necesarios, la memoria también consiste en sacar a la luz las memorias no autorizas, para entender como nos pudimos/podemos convertir en lo que fuimos/somos.

\section{Bibliografía}

- Águila, Gabriela. (2008). "Dictadura, represión y sociedad en Rosario, 1976-1983. Un estudio sobre la represión, y los comportamientos y actitudes sociales en dictadura”. Buenos Aires: Prometeo Libros.

- - "Dictadura, sociedad y genocidio en la Argentina. La represión en Rosario, 1976-1983”. (2004) en Feierstein, Daniel y Levy, Guillermo (comp.), "Hasta que la muerte nos separe. Poder y prácticas sociales genocidas en América Latina”. La Plata, Argentina: Ediciones al Margen.

- Alonso, Luciano y Faldini, Adriana. (2009). "Memoria e historia del pasado reciente. Problemas didácticos y disciplinarios" Santa Fe, Argentina: Universidad Nacional del Litoral. 
- Baczko, Bronislaw. (1991). "Los imaginarios sociales. Memorias y esperanzas colectivas". Buenos Aires, Argentina: Nueva Visión.

- Belinsky, Jorge. (2007). "Lo imaginario: un estudio". Buenos Aires, Argentina: Nueva Visión.

- Blaustein, Eduardo y Zubieta, Martín. (2006). “Decíamos ayer. La prensa argentina bajo el proceso", Buenos Aires, Argentina: Colihue.

- Bretal, Eleonora. (2015). "Rasgos de la cotidianidad en la 'época de los militares', representaciones de ex obreros que no estaban metidos en nada", en Revista Sociohistórica, número 36, Universidad Nacional de La Plata. Facultad de Humanidades y Ciencias de la Educación, Centro de Investigaciones Socio Históricas, La Plata. Recuperado de: http://www.sociohistorica.fahce.unlp.edu.ar/article/view/SH2015n36a01

- Calviero, Pilar. (1998). "Poder y desaparición. Los campos de concentración en la Argentina". Buenos Aires, Argentina: Colihue.

- (2006). "Sujetos sociales y nuevas formas de protesta en la historia reciente de América Latina”. Buenos Aires, Argentina: CLACSO.

- Canelo, Paula. (2011). "El sentido común sobre la última dictadura militar argentina y los desafíos de las ciencias sociales" en Pérez, H. Aelo y Salerno (editores), "Todo aquel fulgor. La política argentina después del neoliberalismo". Buenos Aires, Argentina: Trilce.

- Carassai, Sebastián. (2013). “Los años setenta de la gente común. La naturalización de la violencia". Buenos Aires, Argentina: Siglo XXI.

- Caviglia, Mariana. (2006). "Dictadura, vida cotidiana y clases medias, una sociedad fracturada". Buenos Aires, Argentina: Prometeo.

- Corradi, Juan; Weissfagen Patricia y Garretón Manuel. (1992). Fear at the edge. State Terror and resistance in Latin America, University of California Press, Berkeley and Los Aneles.

- - "El método de destrucción. El terror en la Argentina”, en Quiroga, H. y Tcach, C. (comp.), (1996). "A veinte años del golpe. Con memoria democrática". Rosario, Argentina: Homo Sapiens. 
- Crenzel, Emilio. (2007). "Dos prólogos para un mismo informe. El Nunca Más y la memoria de las desapariciones". Prohistoria, núm. 11. Recuperado desde: https://www.redalyc.org/pdf/3801/380135838003.pdf

- Da Silva Catela. (2010). "Pasados en conflictos. De memorias dominantes, subterráneas y denegadas", en "Problemas de Historia Reciente del Cono Sur", 1ra Edición, Buenos Aires, Argentina: Prometeo.

- Elias, Norbert. (1996). "The germans. Powerstruggles and the development of habitus in the nineteenth and twentieth centuries". New York, USA: Columbia University press.

- Feierstein, Daniel. (2018). “Los dos demonios (recargados)”. Buenos Aires, Argentina: Marea.

- Ferrara, Francisco. (1973). "Qué son las ligas agrarias". Buenos Aires, Argentina: Siglo XXI.

- Ferrer, Aldo. (2010). “La economía argentina. Desde sus inicios hasta principios del siglo XXI'. Buenos Aires, Argentina: Fondo de Cultura Económica.

- Franco, Marina. (2012). "Un enemigo para la nación, orden interno, violencia y “subversión”, 1973-1976". Buenos Aires, Argentina: Fondo de Cultura Económica.

- Franco, Marina y Levín, Florencia. (2007). "Historia reciente. Perspectivas y desafios para un campo en construcción". Buenos Aires, Argentina: Paidós.

- Garbero, Vanesa. (2017). "El terrorismo de estado en Argentina a escala local. Tensiones entre la memoria dominante y memorias locales", en Revista Península, volumen XII, número 1, Buenos Aires, Argentina.

- Ginzburg, Carlo. (1997). "El queso y los gusanos. El cosmos según un molinero del siglo $X V T^{\prime}$. Barcelona, España: Muchnik.

- Gómez, M., Marín L. y Yuli, M. (2007). “El proceso militar de 1976- 1983 en el imaginario social de San Luis, Argentina. Un estudio de casos: "secuelas" en las prácticas y discursos actuales". Fundamentos en Humanidades, volumen VIII.

- Guber, Rosana. (2013). “El salvaje metropolitano. Reconstrucción del conocimiento social en el trabajo de campo", Estudios de comunicación $\mathrm{N}^{\circ}$ 19, Buenos Aires, Argentina: Paidós. 
- - "La dimensión cultural de la crisis en Corrientes". (2002). Periódico electrónico de información alternativa, Recuperado desde:

https://www.rebelion.org/hemeroteca/portada.htm. Fecha de consulta: 14-02-2017.

- Halbwachs, Maurice. (2011). "La memoria colectiva”. Buenos Aires, Argentina: Miño y Dávila.

- Jelín, Elizabeth. (2002). "Los trabajos de la memoria”. Buenos Aires, Argentina: Siglo XXI.

- Kirchner, Néstor, discurso del 24 de marzo del 2004, De la Redacción de Diario Registrado, A 11 años del memorable discurso de Néstor Kirchner, Lunes 23 de marzo de 2015, 15:02 https://www.diarioregistrado.com/politica/a-11-anos-del-memorablediscurso-de-nestor-kirchner a56316a8442bd9ca81b19534f

- Lorenz, Federico. (2007). “Combates por la memoria. Huellas de la dictadura en la memoria", Claves para todos, Colección dirigida por José Nun, Buenos Aires, Argentina: Capital Intelectual.

- Levín, Florencia Paula. (2005). “Arqueología de la memoria. Algunas reflexiones a propósito de Los vecinos del horror. Los otros testigos", en Revista Entrepasados, volumen 28. Buenos Aires, Argentina: Entrepasados.

- Lvovich, Daniel y Bisquert, Jaquelina. (2008). "La cambiante memoria de la dictadura. discursos públicos, movimientos sociales y legitimidad democrática”, colección "25 años, 25 libros". Buenos Aires, Argentina. Biblioteca Nacional.

- - (2006). ¿“Dictadura y consenso. ¿Qué podemos saber?”, en Revista Puentes, año 6, $n^{\circ}$ 17. La Plata, Argentina: Comisión Provincial por la Memoria.

- - (2015). "Sistema político y actitudes sociales en la legitimación de la dictadura militar argentina (1976-1983)", en "La ofensiva cultural norteamericana durante la guerra fría”. Recuperado desde: http://www.cervantesvirtual.com/obra/la-ofensiva-culturalnorteamericana-durante-la-guerra-frial

- Mason, Alfredo. (2007). "Sindicalismo y dictadura: una historia poco contada (19761983) ’. Buenos Aires, Argentina: Editorial Biblos. 
- Mignone, Emilio. (1986). "Iglesia y dictadura, el papel de la iglesia a la luz de sus relaciones con el régimen militar". Buenos Aires, Argentina: Universidad Nacional de Quilmes.

- Morresi, Sergio. (2010). "El liberalismo conservador y la ideología del Proceso de Reorganización Nacional", Revista Sociohistórica / Cuadernos del CISH 27 | primer semestre, Buenos Aires, Argentina.

- Novaro, Marcos. (2010). “Historia de la argentina 1055-2010”, Buenos Aires, Argentina: Siglo XXI.

- COMISIÓN NACIONAL SOBRE LA DESAPARICIÓN DE PERSONAS (CONADEP) Nunca Más. Informe de la Comisión Nacional sobre la Desaparición de Personas, EUDEBA, Buenos Aires, 2006, 7ma edición.

- O’Donnell, Guillermo. (1984). "Democracia de la Argentina: micro y macro", en Oscar Oszlak (comp.), "Proceso", crisis y transición democrática. Tomo 1. Centro Editor de América Latina, Buenos Aires,

- Olivo, Ana, "Anita desde las ligas agrarias. Tierra, trabajo y dignidad", en Muchnik, M. y Cittadini, R. (coord.), Colección "Historias de vida"-Literatura silvestre y popular, Ed. Ciccus, Buenos Aires, 2013.

- Pollak, Michael. (2006). "Memoria, olvido, silencio. La producción social de identidades frente a situaciones límite". Buenos Aires, Argentina: Ediciones al Margen.

- Portelli, Alessandro. (1991). "Lo que hace diferente a la historia oral", en Dora Schwarzstein (comp.), La historia oral. Buenos Aires, Argentina: CEAL.

- - (2016). "Historias orales. Narración, imaginación y diálogo". La Plata, Argentina: Prohistoria Ediciones.

- Pucciarelli, Alfredo R. (2004). "Empresarios, tecnócratas y militares: la trama corporativa de la última dictadura". Buenos Aires, Argentina: Siglo Veintiuno Editores.

- Quiroga, Hugo. (1994). "Los tiempos del Proceso. Conflictos y coincidencias entre políticos y militares, 1976-1983”. Rosario, Argentina: Editorial Fundación Ross.

- Retamozo, Martín. (2011). "Movimientos sociales, política y hegemonía en Argentina” en: Polis, revista latinoamericana (on line), URL: http:// polis.revues.org/1249. 
- Schindel, Estela. (2012). "La desaparición a diario. Sociedad, prenda y dictadura 19751978". Villa María: ed. Eduvim.

- Sorgentini, Hernán. (2003). "Reflexión sobre la memoria y autoreflexión de la historia” en: Revista Brasileira de Historia (on line), vol. 23, número 25.

- - (2013). “¿Por qué traducir a Alessandro Portelli? en: Revista Aleteia (on line), vol. 4, número 7.

- Sarlo, Beatriz. (2005). "Tiempo pasado: cultura de la memoria y giro subjetivo. Una discusión". Buenos Aires, Argentina: Siglo XXI.

- Soprano, G. y Bohoslavsky, E (comps), (2009). “Funcionarios e instituciones estatales en Argentina (de 1880 a la actualidad)’. Buenos Aires, Argentina: UNGS.

- Souroujon, Gastón. (1997). "Contrapuntos: ensayos elegidos sobre autoritarismo y democratización”, en Revista Andamios, México, vol. 8, número 17.

- Strauss, Anselm y Corbin Juliet. (2002). “Bases de la investigación cualitativa. Técnicas y procedimientos para desarrollar la teoría fundamentada”. Colombia: Ed. Universidad de Antioquía.

- Traverso, Enzo. (2007). "Historia y memoria: notas sobre un debate" en: Marina Franco y Florencia Levín (comps.). Historia Reciente. Perspectivas y desafios para un campo en construcción. Buenos Aires, Argentina: Paidós.

- Ulanovsky, Carlos. (2005). “Paren las rotativas 1970-2000”, , Buenos Aires, Argentina: Emecé Editores.

- Vezzetti, Hugo. (2009). "Pasado y presente. Guerra, dictadura y sociedad en la Argentina". Buenos Aires, Argentina: Siglo XXI.

- Vieytes, Rut. (2004). "Metodología de investigación en las organizaciones, mercado y sociedad. Epistemología y técnicas". Buenos Aires, Argentina: Editorial de las Ciencias.

- Vitale, Alejandra. (2015). “CCómo pudo suceder? Prensa escrita y golpismo en la Argentina 1930-1976”. Buenos Aires, Argentina: Eudeba.

- Yerushalmi, Yosef. (1989). "Reflexiones sobre el olvido", en AA.VV., Usos del olvido. Buenos Aires, Argentina: Nueva Visión. 
- Zarrabeitia, César Héctor. (2010). "Temas de política. Monografías, comentario, reseña y ensayo". Corrientes, Argentina: Moglia. 